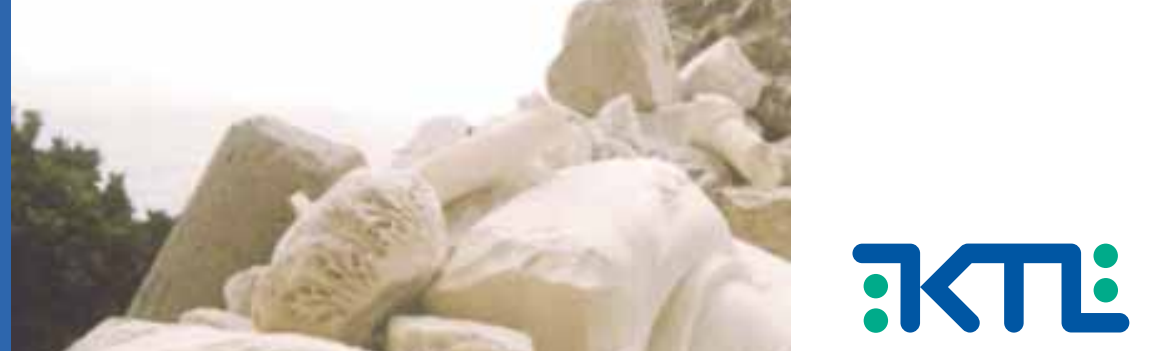

Petteri Sokero

Suicidal Ideation and Attempts

Among Psychiatric Patients with

Major Depressive Disorder

Publications of the National Public Health Institute A 13/2006

Department of Mental Health and Alcohol Research

National Public Health Institute Helsinki, Finland

and

Department of Psychiatry

University of Helsinki, Finland

Helsinki 2006 


\author{
National Public Health Institute, \\ Department of Mental Health and Alcohol Research, \\ Helsinki, Finland \\ and \\ University of Helsinki, \\ Department of Psychiatry, \\ Helsinki, Finland
}

\title{
Suicidal Ideation and Attempts Among Psychiatric Patients with Major Depressive Disorder
}

\author{
Petteri Sokero
}

Academic Dissertation

To be presented with the permission of the Faculty of Medicine, Institute of Clinical Medicine, Department of Psychiatry, University of Helsinki, for public examination at the Christian Sibelius-auditorium,

Välskärinkatu 12, on November $17^{\text {th }}, 2006$, at 12 noon.

Helsinki 2006 


\section{Publications of the National Public Health Institute}

\section{KTL A13/2006}

Copyright National Public Health Institute

\section{Julkaisija-Utgivare-Publisher}

Kansanterveyslaitos (KTL)

Mannerheimintie 166

FIN-00300 Helsinki, Finland

puh. (09) 4744 1, fax (09) 474408

Folkhälsoinstitutet

Mannerheimvägen 166

FIN-00300 Helsingfors, Finland

tel. (09) 4744 1, fax (09) 474408

National Public Health Institute (NPHI)

Mannerheimintie 166

FIN-00300 Helsinki, Finland

tel. $+358-9-4744$ 1, fax +358-9-4744 08

ISBN 951-740-634-7

ISSN 0359-3584

ISBN 951-740-635-5 (pdf)

ISSN 1458-6290 (pdf)

Kannen kuva - cover graphic: Anniina Mikama

Painopaikka Edita Prima Oy

Helsinki 2006 


\section{Supervised by:}

Professor Erkki Isometsä, M.D., Ph.D. Department of Psychiatry, University of Helsinki, Finland Department of Mental Health and Alcohol Reseach

National Public Health Insitute, Helsinki,

Finland

\section{Reviewed by:}

Docent Tero Taiminen, M.D., Ph.D. Department of Psychiatry, University of Turku,

Finland

and

Acting Professor, Docent Sari Lindeman, M.D.,Ph.D.

Department of Psychiatry, University of Oulu,

Finland

\section{Opponent:}

Professor Jukka Hintikka, M.D., Ph.D. Department of Psychiatry, University of Tampere, Finland 


\section{CONTENTS}

Tiivistelmä

$\begin{array}{ll}\text { Abstract } & 9\end{array}$

$\begin{array}{ll}\text { Abbreviations } & 11\end{array}$

$\begin{array}{ll}\text { List of original publications } & 13\end{array}$

1 Introduction 14

2 Review of the literature 16

2.1 Classification of suicidal behaviour 16

2.2 The multifactorial aetiology of suicidal behaviour 16

2.2.1 Familial and genetic factors in suicidal behaviour $\quad 17$

$\begin{array}{ll}\text { 2.2.2 Neurobiology of suicidal behaviour } & 17\end{array}$

2.2.3 Psychological background of suicidal behaviour 20

2.2.3.1 Stress-diathesis model of suicidal behaviour 21

2.2.3.2 Differential activation theory 23

2.3 Suicidal ideation $\quad 23$

2.3.1 Definition of suicidal ideation 23

2.3.2 Epidemiology of suicidal ideation 23

2.3.3 Risk factors for suicidal ideation $\quad 25$

2.4 Suicide attempt 25

2.4.1 Definition of suicide attempt 25

2.4.2 Epidemiology of attempted suicide 26

2.4.3 Risk factors for suicide attempt 26

2.5 Suicide 27

2.5.1 Definition of suicide $\quad 27$

2.5.2 Epidemiology of suicide 27

2.5.3 Risk factors for completed suicide 28

2.6 Prevention of suicidal behaviour 29

2.7 Major depressive disorder $\quad 31$

2.7.1 Diagnosis of MDD 31

2.7.2 Epidemiology of MDD 32

2.7.3 Aetiology of MDD 33

2.7.4 Heritability of MDD 33 
2.7.5 Developmental factors of MDD

$\begin{array}{ll}\text { 2.7.6 Course and outcome of MDD } & 34\end{array}$

2.7.7 Comorbidity of MDD 34

2.7.8 Treatment of MDD $\quad 35$

2.7.8.1 Antidepressant treatment 35

2.7.8.2 Psychotherapeutic treatment 36

2.7.8.3 Electroconvulsive therapy 36

2.7.9 Adherence and attitudes to treatment 36

$\begin{array}{ll}2.8 \text { Suicidal behaviour in MDD } & 37\end{array}$

2.8.1 Epidemiology of suicidal behaviour in MDD 37

2.8.2 Risk factors for suicidal ideation in MDD 38

2.8.3 Risk factors for suicide attempt in MDD 39

2.8.4 Risk factors for completed suicide in MDD 39

2.8.5 Hopelessness and its relation to suicidal behaviour and MDD 40

2.8.6 Limitations in earlier studies $\quad 40$

3 Aims of the study $\quad 41$

4 Materials and methods $\quad 43$

4.1 General study design 43

$\begin{array}{ll}4.2 \text { Screening } & 43\end{array}$

4.3 Baseline evaluation $\quad 44$

4.3.1 Diagnostic measeures 44

4.3.2 Exclusion criteria $\quad 44$

4.3.3 Observer and self-report scales $\quad 44$

4.3.4 Suicidal behaviour $\quad 45$

4.3.5 Adequacy of treatment received 45

4.3.6 Attitudes toward treatment 45

4.4 Follow-up procedure $\quad 46$

4.4.1 Outcome measures and life-chart methodology 46

4.4.2 Suicide attempts during the follow- up 46

4.4.3 Weekly follow-up of suicidal ideation and covariates 47

4.4.4 Prospective follow-up of treatment attitudes and adherence $\quad 47$

$\begin{array}{ll}\text { 4.4.5 Self-reported treatment adherence } & 48\end{array}$

$\begin{array}{ll}\text { 4.4.6 Statistical analyses } & 48\end{array}$ 
5.1 Suicidal ideation and attempts MDD (Study I) 50

5.1.1 Clinical and demographic characteristics of the sample 50

5.1.2 Suicidal ideation and attempts during the current episode $\quad 50$

5.1.3 Risk factors for suicidal ideation and suicide attempts 50

5.2 Risk factors for attempted suicide in MDD (Study II) 53

5.2.1 Suicide attempts during the prospective follow-up 53

5.2.2 Diffrerences between suicide attempters and non-attempters 53

5.2.3 Predictors of suicide attempt during the follow-up 53

5.2.4 Patients who switched to bipolar 53

5.3 Duration and trends of suicidal ideation and depression during the follow-up (Study III) 56

5.3.1 Course of suicidal ideation 56

5.3.2 Baseline factors predicting duration of suicidal ideation $\quad 56$

5.3.3 Predictors for a decline in suicidal ideation 56

5.4 Adequacy, attitudes and adherence to treatments (Study IV) 58

5.4.1 Differences between clinical characteristics and treatment 58

5.4.2 Attitudes and self-reported adherence to treatment 58

6 Discussion $\quad 60$

$\begin{array}{ll}\text { 6.1 Main findings } & 60\end{array}$

6.2 Methods 61

6.2.1 Representativeness of the sample 61

6.2.2 Diagnostic measures 61

6.2.3 Life-chart methodology 61

6.2.4 Drop outs 61

6.2.5 Measurement of suicidal ideation $\quad 62$

6.3 Results 63

6.3.1 Suicidal ideation and attempts among patients with MDD (Study I) 63

6.3.2 Risk factors for suicide attempts in MDD (Study II) 63

6.3.3 Decline in suicidal ideation (Study II) 64

6.3.4 Adequacy, attitudes and adherence to treatments (Study IV) 65

7 Conclusions $\quad 66$

7.1 Conclusions and clinical implications 66

$\begin{array}{ll}7.2 \text { Implications for future research } & 67\end{array}$

8 Acknowledgements $\quad 68$

9 References $\quad 70$ 
Petteri Sokero, Itsemurha-ajatukset ja yritykset vakavasti masentuneilla psykiatrisilla potilailla

Kansanterveyslaitoksen julkaisuja, A13/2006, 94 sivua

ISBN 951-740-634-7; 951-740-635-5 (pdf-versio)

ISSN 0359-3584; 1458-6290 (pdf-versio)

http://www.ktl.fi/portal/4043

\section{TIIVISTELMÄ}

Tämä tutkimus on osa Kansanterveyslaitoksen Mielenterveyden ja Alkoholitutkimuksen osaston ja Helsingin ja Uudenmaan sairaanhoitopiirin Peijaksen sairaalan Psykiatrian tulosyksikön vakavan masennustilan etenevää tutkimusta (Vantaa Depression Study), jossa seurataan 269 ajankohtaisesta vakavasta masennustilasta kärsivää psykiatrisen erikoissairaanhoidon avohoito- ja sairaalapotilasta.

806 aikuispotilasta, iältään 20-59v, seulottiin depressiivisten oireiden osalta ja 542 haastateltiin puolistrukturoidulla haastattelumenetelmällä (SCAN). Tutkimukseen valikoitui 269 potilasta (miehiä 72, naisia 197), jotka täyttivät ajankohtaisen vakavan masennustilan oirekriteerit. Heidät haastateltiin puolistrukturoiduin haastattelumenetelmin myös muiden psykiatristen häiriöiden poissulkemiseksi. Poissulkukriteereinä olivat kaksisuuntainen mielialahäiriö (tyyppi I ja II), skitsofrenia ja muut psykoosit, skitsoaffektiivinen häiriö sekä orgaaninen tai kemiallisen aineen aiheuttama mielialahäiriö. $6 \mathrm{kk}$ ja $18 \mathrm{kk}$ seurantavaiheissa potilaat haastateltiin uudelleen vastaavin menetelmin kuin sisäänottovaiheessa. Itsetuhokäyttäytymistä kartoitettiin sekä tutkimukseen sisäänotto- että tutkimuksen seurantavaiheissa psykometrisellä kyselykaavakkeella (Scale for Suicidal Ideation), haastattelukysymyksin ja sairauskertomustietojen perusteella. Niitä potilaita, jotka sisääntulovaiheessa arvioitiin itsetuhoisiksi (potilaat, joilla esiintyi voimakkaita mielen täyttäviä itsemurha-ajatuksia), seurattiin viikottain itsemurha-ajatusten, masennusoireiden, toivottomuuden ja ahdistuneisuuden suhteen.

Tässä tutkimuksessa todettiin itsemurha-ajatusten olevan varsin yleistä masennuspotilaiden joukossa. Lähes 60\%:lla masennuspotilaista todettiin itsemurha-ajatuksia ja $15 \%$ potilaista oli yrittänyt itsemurhaa sisäänottovaiheessa. Potilaiden, joilla esiintyi itsemurha-ajatuksia tai jotka olivat yrittäneet itsemurhaa, yleinen oiretaso oli vakavampaa kuin niillä masennuspotilailla, joilla ei esiintynyt itsemurha-alttiutta.

Seuranta-aikana $8 \%$ potilaista yritti itsemurhaa vähintään kerran. Riski itsemurhayritykselle oli selvästi suurempi masennusepisodin aikana verrattuna remissiojaksoon (masennuksen elpymisvaiheeseen). Seurannan aikana tapahtuvaa itsemurhayritystä ennustivat parisuhteen puuttuminen, aikaisemmat itsemurhayritykset ja masennusjakson pituus. 
Itsemurha-ajatukset lievittyivät suurimmalla osalla potilaista 2-3 kuukauden kuluessa. Niillä masennuspotilailla, joiden yleinen oiretaso oli vakavampi seurannan alussa, itsemurha-ajatukset myös kestivät kauemmin. Sekä depressio-oireiden että toivottomuuden tason lievittyminen edelsi itsemurha-ajatusten laskua. On mahdolista, että molemmilla, sekä depressiooireiden että toivottomuuden lievittymisellä, on näinollen kausaalinen rooli itsetuhoisen prosessin suunnanmuutoksessa. Täten masennuksen hyvä hoito näyttäisi olevan tehokas keino myös itsemurhien ennaltaehkäisemisessä.

Itsetuhoiset potilaat, eli kaikki ne potilaat, joilla esiintyi vakavia itsemurha-ajatuksia tai ne, jotka olivat yrittäneet itsemurhaa (joko yhden tai useamman kerran), saivat useammin lääkehoitoa ja heillä oli tiiviimpi hoitokontakti psykiatriseen erikoissairaanhoitoon kuin masennuspotilailla, joilla ei esiintynyt itsetuhokayttäytymistä. Myös heidän asenteensa antidepressiiviseen lääkitykseen oli suotuisampi ja kiinnittyminen hoitoon yhtä hyvä kuin muillakin masennuspotilailla.

Vaikka itsetuhoiset masennuspotilaat tiedetään moniongelmaisiksi, tämä tutkimus ei tue sitä käsitystä, että heidän asenteensa hoitoon tai sen jatkuvuuteen olisi heikompi kuin masennuspotilailla, joilla ei esiinny itsetuhokäyttäytymistä. Ongelmat, jotka liittyvät hoidon jatkuvuuteen näyttäisivät olevan yhteisiä kaikille psykiatrisille potilaille.

Avainsanat: depressio, itsemurha-ajatukset, itsemurhayritys 
Petteri Sokero, Suicidal ideation and attempts among psychiatric patients with major depressive disorder

Publications of the National Public Health Institute, A13/2006, 94 Pages

ISBN 951-740-634-7; 951-740-635-5 (pdf-version)

ISSN 0359-3584; 1458-6290 (pdf-version)

http://www.ktl.fi/portal/4043

\section{ABSTRACT}

This study is part of an ongoing collaborative research and development project, the Vantaa Depression Study (VDS), between the department of Mental Health and Alcohol Research of the National Public Health Institute, Helsinki and the Department of Psychiatry of Helsinki University Hospital (HUCH), Peijas hospital (the Peijas Medical Care District, PMCD), Vantaa. The VDS is a prospective, naturalistic cohort study of 269 secondary-level care psychiatric out- and inpatients with a new episode of Diagnostic and Statistical Manual of Mental Disorders, $4^{\text {th }}$ edition (DSM-IV) major depressive disorder (MDD).

VDS involved 806 adult patients (aged 20-59 years), who were screened for a possible new episode of DSM-IV MDD. 542 consenting patients were interviewed with a semistructured interview [the WHO Schedule for Clinical Assessment in Neuropsychiatry (SCAN), Version 2.0]. 269 patients $\left(\mathrm{N}_{\text {males }}=72, \mathrm{~N}_{\text {females }}=197\right)$ with a current DSM-IV MDD were included in the study. Further they were interviewed with semistructured interviews to assess all other psychiatric diagnoses. Exclusion criteria were DSM-IV bipolar disease I and II, schizophrenia and other non-affective psychoses, schizoaffective disorder, organic and substance-induced mood disorders. At 6- and 18-month follow-up the interviews were repeated. Suicidal behaviour was investigated both at intake and follow-up by using a psychometric scale (Scale for Suicidal Ideation) and interviewer's questions as well as the patient's psychiatric records. Patients, who reported suicidal ideation while entering the study were followed up weekly, and their level of suicidal ideation, hopelessness, anxiety and depression was measured.

In this study suicidal ideation (i.e. thoughts serving the agent of one's own death) was common among psychiatric patients with MDD. Almost $60 \%$ of the depressed patients reported suicidal ideation and $15 \%$ of patients attempted suicide at the baseline. Patients with suicidal ideation or attempts had a clearly higher level of overall psychopathology than non-suicidal patients. 
During the 18-month follow-up period $8 \%$ of patients attempted suicide. The risk of an attempt was markedly higher ( $R R=7.54$ ) during an episode of major depression compared with a period of remission. Suicide attempt during the follow-up period was predicted by lack of partner, a history of previous suicide attempts and time spent in depression.

Suicidal ideation resolved for most of the suicidal patients during the first 2 to 3 months. The duration of suicidal ideation was longer for patients with an initially higher level of psychopathology. Declines both in depression and hopelessness independently predicted the subsequent decline in suicidal ideation. They both could have a causal role in reversing the suicidal process. Thus effective treatment of depression is a credible measure in suicide prevention.

Patients with suicidal behaviour often received more antidepressants and had more frequent appointments with mental health professionals than non-suicidal patients. Suicidal patients had also more favourable attitudes towards antidepressant treatment and comparable adherence to treatment than those not suicidal.

Although we know that problems of suicidal patients comprise several different domains, this study does not support the conception that patient attitudes or adherence to treatments would be a factor differentiating suicidal patients from non-suicidal. Instead, problems with adherence or attitudes seem to be generic to all psychiatric care.

Keywords: depression, suicidal ideation, suicide attempt. 


\section{ABBREVIATIONS}

$\mathrm{AD}$

APA

BAI

BDI

BPD

CI

CBT

CSF

DA

DALY

DAT

DSM-IV

DST

EDA

ECA

ECT

FINHCS

GAD

HAM-D

HR

HS

5-HTP

5 HTT

$\mathrm{HUCH}$

HVA

ICD-10

IPT

IRLE

LIFE

NESARC

MAO

MDD
Antidepressive medication

American Psychiatric Association

Beck Anxiety Inventory

Beck Depression Inventory

Borderline Personality Disorder

Confidence Interval

Cognitive-Behavioural Therapies

Cerebrospinal fluid

Dopamine

Disability adjusted life years

Differential Activation Theory

Diagnostic and Statistical Manual of Mental Disorders, $4^{\text {th }}$ edition

Dexamethasone Suppression Test

Electrodermal Activity

Epidemiological Catchment Area Study

Electroconvulsive therapy

Finnish Health Care Survey

Generalized Anxiety Disorder

Hamilton Rating Scale for Depression

Hazard Ratio

Beck Hopelessness Scale

5-hydroxy-tryptophan

Serotonin transporter gene

Helsinki University Central Hospital

Homovanillinic acid

International Classification of Diseases, $10^{\text {th }}$ edition

Interpersonal Psychotherapy

Interview for Recent Life Events

Longitudinal Interval Follow-up Evaluation

National Epidemiologic Survey on Alcohol and Related Conditions

Monoamine Oxidase

Major Depressive Disorder 
MDE

NA

NCS

NCS-R

NEMESIS

NS

OCD

OR

PMCD

PSSS-R

PTSD

RR

SA

SI

SCAN

SCID-II

SOFAS

SPSS

SSI

TH

TPH

VDS

WHO

YLD
Major Depressive Episode

Noradrenaline

National Comorbidity Survey

National Comorbidity Survey - Replication

Netherlands Mental Health Survey and Incidence Study

Non-Suicidal

Obsessive Compulsive Disorder

Odds Ratio

Peijas Medical Care District

Perceived Social Support Scale - Revised

Post Traumatic Stress Disorder

Relative Risk

Suicide Attempt

Suicidal Ideation

Schedules for Clinical Assessment of Neuropsychiatry

Structured Clinical Interview for DSM-III-R personality disorders

Social and Occupational Functioning Assessment Scale for DSM-IV

Statistical Package for the Social Sciences for Windows

Scale for Suicidal Ideation

Tyrosine Hydroxylase

Tryptophan Hydroxylase

Vantaa Depression Study

World Health Organization

Years lost due to disability 


\section{LIST OF ORIGINAL PUBLICATIONS}

This thesis is based on the following original articles referred to in the text by their Roman numerals:

I Sokero TP, Melartin TK, Rytsälä HJ, Leskelä US, Lestelä-Mielonen PS, Isometsä ET: Suicidal ideation and attempts among psychiatric patients with major depressive disorder.

Journal of Clinical Psychiatry 2003 Sep; 64(9): 1094-1100.

II Sokero TP, Melartin TK, Rytsälä HJ, Leskelä US, Lestelä-Mielonen PS, Isometsä ET: Prospective study of risk factors for attempted suicide among patients with DSM-IV major depressive disorder.

British Journal of Psychiatry 2005 Apr; 186: 314-318.

III Sokero TP, Eerola MH, Rytsälä HJ, Melartin TK, Leskelä US, Lestelä-Mielonen PS, Isometsä ET: Decline in suicidal ideation among patients with MDD is preceded by decline in depression and hopelessness.

Journal of Affective Disorders 2006 Oct; 95(1-3):95-102.

IV Sokero TP, Melartin TK, Rytsälä HJ, Leskelä US, Lestelä-Mielonen PS, Isometsä ET: Adequacy of, attitudes towards and adherence to treatments by depressed patients with or without suicidal behaviour (submitted).

These articles are reproduced with the kind permission of their copyright holders. 


\section{INTRODUCTION}

Approximately one million people worldwide commit suicide annually. Every 40 seconds a person commits suicide somewhere in the world. The number of lives lost each year through suicide exceeds the number of deaths due to homicide and war combined. Suicidal behaviour has become a major public health problem throughout the world. Suicide is one of the leading causes of death in the world, especially in Western countries and among young adults it is the leading cause, this is also the case in Finland. It is estimated that every suicide has serious impact on at least six other people and the psychological, social and financial impact of suicide on the family and community is immeasurable.

Suicidal behaviour - suicidal ideation, suicide attempt and completed suicide - probably represents a continuum of self-harming behaviours. Suicidal behaviour as a concept includes the tendency, thoughts or acts of self-harming behaviour or life-threatening risks. Suicidal behaviour can be direct - suicidal ideation, suicide attempt or completed suicide, or indirect - such as risky driving, high-risk hobbies, hazardous alcohol drinking, drug misuse or neglecting the management of physical illness. Acute suicidal behaviour can be an escape from an unbearable situation or state of mind, while chronic suicidal behaviour can be seen as a part of person's life story, emerging as a possible solution in times of crises. When looking at the prevalence of different types of suicidal behaviour, prevalence of completed suicide presents only the tip of the iceberg. Non-fatal suicidal behaviour - suicidal ideation and suicide attempts are far more common, especially among young people. The number of suicide attempts may be up to 20 times or more than the number of completed suicides.

Attempted suicide or deliberate self-harm is common, often repeated and denotes a risk of subsequent suicide. It represents considerable psychological distress and it is often linked to long-standing adversity and acute life-events.

Studies on suicide and suicidal behaviour have revealed that suicide is a multifactorial act. Since Durkheim (1897) the importance of social factors, stressors, familial factors etc. have been recognized. The majority of people who commit suicide have a diagnosable mental disorder and suicidal behaviour is more frequent in psychiatric patients. Suffering from any mental disorder has been associated with a significantly elevated risk of premature death. Depression is the most common mental disorder in completed suicide and also one of the most important risk factors for all suicidal behaviour. Other common diagnostic categories among people completing suicide are personality disorders and substance use disorders (Henriksson et al., 1993). 
Major depressive disorder (MDD) is a highly prevalent, aetilogically multifactorial and clinically heterogenous disorder. It is also one of the most important mental disorders in terms of public health impact. According to WHO assessed Global Burden of Disease analysis, unipolar depressive disorders are ranked as the fourth leading cause of burden among all diseases and the leading cause of years lost due to disability (YLDs) in the year 2000. While the estimates demonstrate the current high level of burden resulting from depressive disorders, the outlook for the future is worse. If current trends for demographic and epidemiological transition continue, the burden of depression will increase and by the year 2020 depression will become the second leading cause of disability adjusted life years (DALYs) lost. Worldwide it will be second only to ischaemic heart disease and in the developed regions depression will be the highest ranking cause of burden of disease (Murray \& Lopez, 1996). Depression can affect individuals at any stage of the life span. It is essentially an episodic recurring disorder. Epidemiological studies show that treatment for depression is often inadequate or depression is unrecognized. Depression appears to be a chronic illness with a high risk of recurrence over one's lifetime, especially when adequate treatment is not available. Substantial numbers of depressive patients end their lives by committing suicide. Suicide remains one of the most common outcome of depression.

The association between suicidal behaviour and MDD is well known. Studies have usually focused on completed suicide and MDD, but it is essentially important to study non-fatal suicidal behaviour in MDD. This gives us more comprehensive information concerning the prevention of suicides.

The Vantaa Depression Study (VDS) is a prospective, naturalistic, research and development study of 269 secondary-level care psychiatric out- and inpatients with a new episode of Diagnostic and Statistical Manual of Mental Disorders, $4^{\text {th }}$ edition (DSM-IV) MDD. In the VDS the predictors of chronicity, recurrences, suicidal behaviour as well as functional and work disability are investigated and the adequacy of treatment evaluated. The present thesis focuses on suicidal behaviour among depressive patients followed up for 18 months. 


\section{REVIEW OF THE LITERATURE}

\subsection{Classification of suicidal behaviour}

Suicidal behaviour as a concept includes the tendency, thoughts or acts of self-harming behaviour or life threatening risks. Currently suicidal behaviour is characterized with a broad variety of terminology in the literature of suicide research. We have the American Psychiatric Association (APA) definitions of terms in use (American Psychiatric Association, 2003), but there is no generally accepted classification of suicidal behaviours, and this can also be a source of some confusion (for example: attempted suicide - self harm - parasuicide). Suicidal behaviour can vary with respect to manifestation, permanence, seriousness and lethality.

During the past decades there has been debate whether those attempting suicide and those completing, present a single or two separate populations (Linehan, 1986; Beautrais, 2001). It seems that they are overlapping populations. The three types of suicidal behaviour suicidal ideation, suicide attempt and completed suicide, can be seen as a continuum of self-harming behaviours (Beck et al. 1973).

\subsection{The multifactorial aetiology of suicidal behaviour}

Several arguments suggest that suicidal behaviour is an independent disorder, although psychiatric disturbances are major contributing factors. More than $90 \%$ of suicide victims and most of the attempters, as well ideators have a psychiatric disorder (Robins et al., 1959; Dorpat \& Ripley, 1960; Barraclough et al., 1974; Rich et al., 1988; Henriksson et al., 1993; Zimmerman et al., 1995; Beautrais et al., 1996; Mann, 2002; 2005).

However, although the presence of a psychopathology is a strong predictor for suicide, even in the psychiatric groups at the highest risk, only a minority of people with these diagnoses attempt or commit suicide, indicating the importance of a diathesis or predisposition to suicidal behaviour that is independent of the main psychiatric disorders (Mann, 2003; Turecki, 2005).

Traditionally, risk factors for suicidal behaviour have been divided into medical (e.g. mental disorders), psychosocial (e.g. divorce), cultural (e.g. lack of religious commitment) and socio economic (e.g. unemployment). Recently, the risk factors behind suicidal behaviour were also categorized into three main groups: genetic and environmental factors and interaction between these two (Marusic \& Farmer, 2001). 


\subsubsection{Familial and genetic factors in suicidal behaviour}

Studies analyzing family, twins and adoption have been concordant in suggesting the implication of genetic factors in suicidal behaviour. Persons who attempt or commit suicide, have a significantly increased rate of suicidal acts in their families (Roy, 1983; Linkowski et al., 1985; Pfeffer et al., 1994). Twin studies as well as adoption studies have also shown a high concordance in the rates for completed suicides and suicide attempts (Schulsinger et al., 1979; Roy et al., 1991; 1995; Statham et al., 1998; Brent \& Mann, 2005). For example, the concordance of suicide for identical twins is $11.5 \%$ and for fraternal twins 2\% (Roy et al., 1991). The heritability of suicidal behaviour, especially suicide, is comparable to the heritability of other major psychiatric disorders, such as bipolar disorder and schizophrenia. It is estimated that $43 \%$ of the variability in suicidal behaviour may be explained by genetics, while the remaining $57 \%$ may be explained by environmental factors (Roy, 1993a; Roy et al., 1995; McGuffin et al., 2001; Mann, 2002).

\subsubsection{Neurobiology of suicidal behaviour}

Different neurotransmitter systems have been the most researched area in the field of neurobiology of suicidal behaviour. Post-mortem brain analyses have provided us a lot of valuable data on the serotonergic, noradrenergic and dopaminergic neurotransmitter systems and the cellular morphology of suicide victims. Studies have shown that altered serotonergic function is associated with the diathesis for suicidal behaviour (Mann et al., 1998). Serotonergic abnormalities are related to many psychopathological dimensions such as anxiety, depressed mood, impulsivity and aggression. Post-mortem brain receptor mapping studies suggest that reduced serotonergic input to the orbital prefrontal cortex, hypothalamus, occipital cortex and brainstem may be deficient in persons who are at risk of suicidal behaviour and may underlie a general propensity for aggressive and impulsive behaviours (Arango et al., 1995; Mann et al., 1996; 2000). Serotonergic hypofunction appears to be associated with more lethal suicidal behaviour (Mann et al., 1992; Malone et al., 1996). This abnormality could be localized to the ventromedial prefrontal cortex (Arango et al., 1995). Alterations were observed on the receptor level, as postsynaptic 5-HT1A and 5-HT2A receptors were found to be upregulated in prefrontal cortex and this increase was suggested as being a compensatory mechanism to the low activity of the serontonergic neurons (Mann, 2003). 5-HT1A upregulation seems to be localized to the ventral prefrontal cortex, a region that is involved in behavioural and cognitive inhibition, and low serotonergic input may contribute to impaired inhibition, creating a greater propensity to act upon suicidal or aggressive feelings (Arango et al., 1995; Mann, 2003).

These findings are underlined by investigation with fenfluramine. Malone et al. (1996) found that fenfluramine induced an increase in prolactin secretion in healthy people, but in suicide attempters with a higher degree of lethality, the increase was more blunted. 
Only few post-mortem studies covered alterations of the noradrenergic or dopaminergic systems. The main findings were decreased noradrenalin (NA) levels in the brainstem and increased alpha2-adrenergic receptor densities, suggested as being upregulated due to the NA deficit (Ordway et al., 1994a). The results with tyrosine hydroxylase (TH) were divergent, as both increased (Ordway et al., 1994b) and decreased immunoreactivity were observed (Biegon \& Fieldus, 1992). For dopaminergic system no alterations were found (Sumiyoshi et al., 1995; Hurd et al., 1997). In a recent study, the cerebrospinal fluid (CSF) of depressed suicide attempters demonstrated reduced homovanillinic acid (HVA) levels, but not in depressed non-attempters, thus suggesting a relation of dopamine (DA) to suicide but not to depression (Sher et al., 2006).

The specific genes that contribute to suicide risk independently of associated psychiatric disorders are unknown. On the basis of the neurobiological findings, genetic studies have been carried out in order to elucidate the genetic contribution to the vulnerability of suicidal behaviour. As there is convincing evidence that a serotonergic dysfunction is involved in the biological susceptibility to suicide, the majority of studies are focusing with genes of the serotonin pathway as possible candidates (Bondy et al., 2006).

As it is believed that the variability of serotonergic neurotransmitters plays a pivotal role in individual differences on mood, impulsiveness and aggression, it is no surprise that molecular genetic studies of suicide and suicidal behaviour focus on serotonergic genes. Genes related to the serotonergic system are candidate genes worthy of study as part of the genetic diathesis for suicidal behaviour. These candidate genes can be classified into three subgroups:

1. Gene involved in synthesis of serotonin (tryptophan hydroxylase - TPH).

2. Genes involved in serotonergic neurotransmission (serotonin transporter - 5HTT).

5HTT regulates re-uptake of serotonin into pre-synaptic neuron and different serotonin receptors that also regulate neurotransmission.

3. Genes involved in serotonin catabolism (monoamine oxidase - MAO).

TPH is the rate-limiting enzyme in serotonin (5-HT) biosynthesis, converting the amino-acid tryptophan to 5-hydroxy-tryptophan (5HTP), which is further decarboxylated into 5-HT. TPH gene was among the first candidate genes for association studies of suicidality. Two different TPH isoforms (TPH1 and TPH2) have been identified.

There are several studies focusing on TPH1 polymorphism in the frame of depressed, bipolar, schizophrenic or alcoholic patients. Although the numbers of patients within the diagnostic categories seemed to be sufficient, the number of those with suicidal attempts was small in most studies. Three recent meta-analyses pooled results from individual studies in order to test whether TPH1 polymorphisms affect the vulnerability for suicidal behaviour (Lalovic \& Turecki, 2002; Rujescu et al., 2003; Belliver et al., 2004). In their 
combined results Lalovic and Turecki (2002) found no association between suicidal behaviour and TPH1 polymorphism. Rujescu et al. (2003) found a weak, but yet highly significant association, which Belliver et al. (2004) could replicate by a further, more refined meta-analysis. However, the positive results found in some studies (Mann et al., 1997; Souery et al., 2001; Abbar et al., 2001; Turecki et al., 2001), could not be replicated in all studies and the list of negative findings is long. The impact of the TPH1 gene on suicidal behaviour remains still ambiguous because of discrepancy of the results together with the small number of patients, the diagnostic heterogeneity with either committed suicide or a history of suicidal attempts, and finally because of the use of different markers. The identification of the brain-specific, second isoform TPH2 gene, promised to be a step forward in investigating the genetic contribution to suicidality, as this isoform apparently plays a more important role in the synthesis of brain serotonin and thus may be a better candidate gene. However, the number of studies using the TPH2 as the candidate gene is small (Zill et al., 2004; Kennedy et al., 2003; De Luca et al., 2005; Zhou et al., 2005). The results so far are promising, although the functional consequences of these polymorphisms are unknown and the data on TPH2 gene are somewhat limited.

The serotonin transporter (5-HTT) has two allelic variants: long and short. The short form was hypothesized to be associated with impulsive aggression and suicidal behaviour (Mann et al., 2000). Some studies found an association between the short form and violent suicidal behaviour but, also in contrast to these positive findings, a variety of studies did not observe any association to suicidal behaviour. Despite the many discrepant results there is still an ongoing interest on genetic variants of 5-HTT as the possible indicator of suicidality (Bondy et al., 2006).

Studies focusing on serotonin receptors (5-HT2A, 5-HT1A) or on genes involved in serotonin catabolism (tyrosine hydroxylase, monoamine oxidase A) have been interesting, but the results so far have mostly not been convincing (Bondy et al., 2006).

The association of low concentrations of 5-hydroxyindoleatic acid (5-HIAA) in the CSF and suicidal behaviour was first reported by Åsberg et al. (1976) and since that replicated in several studies (Mann, 2003; Samuelsson et al., 2006). Also electrodermal activity (EDA) (Wolfersdorf \& Straub, 1994) and $\beta$-adrenergic receptor binding (Little et al., 1993) have been investigated, but the findings have been not consistent. Non-suppression on the dexamethasone suppression test (DST) in depression has been found to be associated with suicidal behaviour, especially completed suicide. The relationship between attempted suicide and DST has been less consistent (Yerevanian et al., 2004). 


\subsubsection{Psychological background of suicidal behaviour}

Early cognitive accounts of suicidal behaviour were developed from cognitive theories of depression (Beck \& Greenberg, 1971; Beck et al., 1975). Suicidal patients were assumed to share the frequent occurence of depressed patients' negative thinking, compounded by logical errors, and a tendency for long-term belief structures to be activated by current depression. Freud proposed in the influential 1917 paper, Mourning and Melancholia, that most individuals cope with the loss of a loved person through the experience of mourning. However, he believed that there are other vulnerable individuals for whom the loss experience is unbearable and generates enormous anger. The individual feels ambivalence but preserves the mental image of the loved one by internalization and it becomes part of the ego. Feelings of anger towards the lost objective are not possible to express and so they are transformed into self-sensure and the wish to harm oneself. When these feelings reach a critical pitch, they lead to the urge to destroy the self. Beck with his colleagues $(1975$; 1990) showed in their research that there is a strong relationship between life stress and suicidal behaviour. When depressed patients believe that there is no solution to their problems, they consider suicide as a way out of an intolerable and hopeless situation. Hopelessness as it occurs in depressed patients may be viewed as characteristics related to both state and trait. During depression, hopelessness escalates and then subsides over the course of illness. Cognitive research on suicide and risk prediction has developed a model of suicidal behaviour in which hopelessness is a key psychological variable. Hopelessness has been found to play a major role in suicidal behaviour, and in many cases hopelessness has proven to be a better predictor of suicidal intent than depression, and is believed to mediate the relationship between depression and suicidal behaviour. Further research emphasized the widespread impairment of interpersonal problem solving in suicidal patients. Among the variables studied in suicidal patients, depression, hopelessness and problem solving have become a recurrent theme.

Suicidal ideation arises as a symptom of depression, especially if there are reasons for a person to feel hopelessness with regard to the future. Still, the majority of individuals who experience suicidal ideation do not attempt suicide (Kessler et al., 1999). It is important to explain how or why suicidal ideation arises and why it is maintained and exacerbated to the point of a possible suicide attempt. Ringel introduced the concept of the Presuicidal Syndrome which has three principal components: constriction, inhibited aggression turned toward the self and suicidal fantasies. The Presuicidal Syndrome relates to specific psychic state of mind that can lead to suicidal acts. It is proposed that the Presuicidal Syndrome provides a basis for better judgement of the danger of suicide and makes more focused suicide prevention possible (Ringel, 1976). Williams et al. (2001) suggested recently that suicidal ideation and behaviour arise from feelings of entrapment, that there is no escape, and that this represents a particular pattern of information processing concerning one's self and the world. Suicidal ideation can last only a short while if one can think of other, alternative ways to solve problems. Impairment in problem solving reduces this capacity. Suicidal feelings may alleviate if the person feels that he 
or she has something to look forward in the future, some important reasons for living. Hopelessness with regard to the future takes away these possibilities. The combination of a poor problem-solving capacity and hopelessness has become the main object of research interested in psychological process.

\subsubsection{Stress - diathesis model of suicidal behaviour}

Although suicidal behaviour is episodic, occurring most often when a person is in an episode of depression and not when they are in remission, not all people who suffer from recurrent depression become suicidal, and some suicidal behaviour occurs in individuals who are not clinically depressed. Thus, a psychiatric disorder is generally a necessary, but insufficient condition for suicide. Mann et al. (1999) proposed a stress-diathesis model in which the risk for suicidal acts is not determined merely by a psychiatric illness (the stressor) but also by a diathesis (Figure 1). They wanted to develop a model to help determine who remains vulnerable, despite seeming to have recovered, and how this underlying vulnerability relates to the acute suicidal state. The diathesis may be reflected in the tendencies to experience more suicidal ideation and to be more impulsive and thus being more likely to act on suicidal feelings. In their study Mann et al. (1999) found that a trait factor, such as aggression/impulsivity, was significant in distinguishing past suicide attempters from non-attempters. This categorized individuals at risk from suicide attempts regardless of psychiatric diagnosis. Their model showed that subjective depression, hopelessness and suicidal ideation were greater in suicide attempters than in non-attempters despite comparable rates of objective severity for depression or psychosis. One stressor is almost invariably the onset or acute worsening of a psychiatric disorder, but other types of stressors, such as a psychosocial crisis, can also contribute. The diathesis for suicidal behaviour includes a combination of factors such as sex, religion, familial and genetic components, childhood experiences, psychological support system, availability of highly lethal suicide methods and various other factors (Mann, 2002). 


\section{Figure 1. A model for suicidal behaviour}

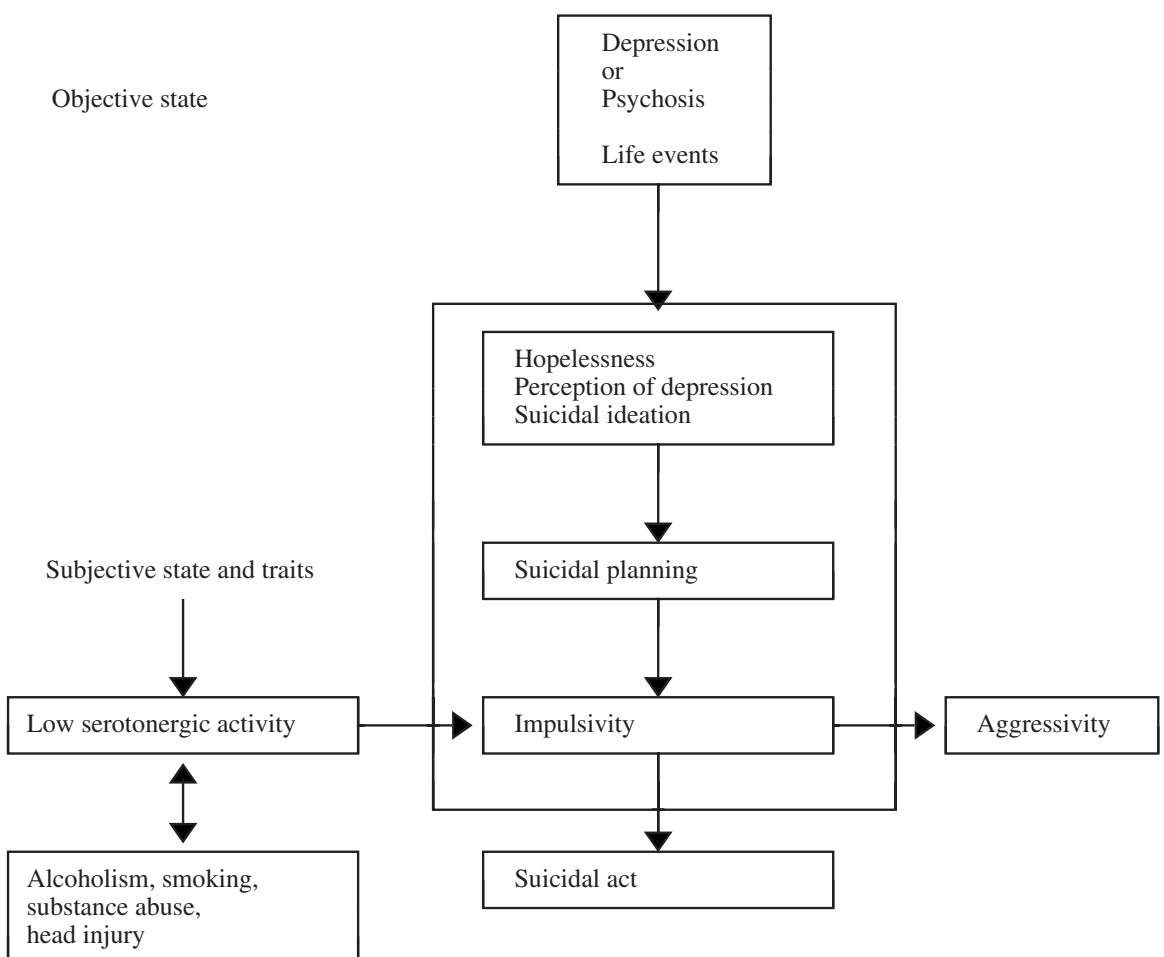

Mann JJ et al. Am J Psychiatry 1999;156:181-189

Reprinted with a permission of American Psychiatric Association. 


\subsubsection{Differential activation theory}

Teasdale et al. (1988) proposed a differential activation theory (DAT), which suggests that during episodes of depression, associations are formed between sad mood and a constellation of negative processing bias. With each occurring episode of depression, the network of depressive cognitions is strengthened, elaborated and becomes increasingly accessible. Recently Joiner et al. (2003) and Lau et al. (2004) suggested that this theory could be extended to the explanation of recurrence of suicidal behaviour. Painful and fear-inducing qualities of suicidal behaviour can diminish with repetition, while opposing processes may intensify. Williams et al. (2005a; 2005b; 2006) refined this theory further in their reports. DAT suggests that the risk of future suicidality is dependent on the extent to which suicidal thoughts and plans have become a part of the processing pattern that is reactivated when low mood reoccurs.

\subsection{Suicidal ideation}

\subsubsection{Definition of suicidal ideation}

Suicidal ideation is defined as thoughts serving the agent of one's own death. It may vary in seriousness depending on the specificity of suicide plans and the degree of suicidal intent (American Psychiatric Association, 2003). Suicidal ideation can be manifested from transient thoughts with respect to the worthlessness of life and death wish, to permanent, concrete plans for killing oneself and obsessive preoccupation with self-destruction. Suicidal ideation may be an aspect of depressed mood and also from the other point of view, a coping strategy with such a mood. It is also correlated closely with hopelessness. Suicidal ideation can be of a habitual or chronic as well as of an acute nature (Goldney et al., 1989; Diekstra \& Garnefski, 1995).

\subsubsection{Epidemiology of suicidal ideation}

Suicide ideation, which comprises suicidal thoughts or threats devoid of action, is more common than suicide attempts and completed suicides and its prevalence varies widely. Lifetime prevalence of suicidal ideation has been reported to range from $2 \%$ to $18 \%$ (Kessler et al., 1999; Weissman et al., 1999). In epidemiological studies the prevalence of suicidal ideation has been reported since the 1970s. Depending on the setting of each particular study, the 12-month prevalence has varied from 2.3\% to $8.7 \%$ (Schwab et al., 1972; Paykel et al., 1974; Vandivort \& Locke, 1979; Crosby et al., 1999, Goldney et al., 2000). In the well-known large epidemiological studies National Comorbidity Survey (NCS) and National Comorbidity Survey-Replication (NCS-R), the 12-month prevalence of suicidal ideation was found to be $2.8 \%$ and 3.3\%, respectively (Kessler et al., 1999; 2005). Kessler 
et al. (2005) estimated that there are approximately 3000/100 000 suicide ideators in the United States each year with 14/100 000 suicide completers. In a Greek study, Madianos et al. (1993) reported the prevalence of suicidal ideation by gender for two waves, 1978 and in 1984. In the first wave, $2.8 \%$ of males and $6.8 \%$ of females reported suicidal ideation during the last 12 months and in the second, 5.9\% and $14.9 \%$, respectively.

Suicidal ideation can vary significantly in different age groups. Suicidal ideation among young adults has been suggested to be around 10-12\% (Goldney et al., 1989) while it is $4 \%$ among the elderly (Skoog et al., 1996).

In the Finnish study Hintikka et al. (2001) investigated with questionnaires (BDI) in a nationwide sample the incidence of suicidal ideation both at the baseline and at 12-month follow-up. The incidence of overall suicidal ideation was reported as $3.8 \%$, and $3.1 \%$ for females and $4.6 \%$ for males, respectively. Usually suicidal ideation is equally common among males and females, or slightly more common among females, but in Finland this does not seem to be the case.

Table 1. Risk factors for suicidal behaviour.

\begin{tabular}{|c|c|c|c|}
\hline Variable & Suicidal Ideation & Suicide Attempt & Completed Suicide \\
\hline Gender & female/male & female & male \\
\hline Age & younger & younger & advancing \\
\hline Marital status & non-married / single & divorced & single / divorced / widowed \\
\hline Education & $+/-$ & low & \\
\hline Economical problems / unemployment & + & + & \\
\hline \multicolumn{4}{|l|}{ Psychiatric disorders } \\
\hline Major Depressive Disorder & + & + & + \\
\hline Personality disorders & & + & + \\
\hline Substance Use Disorder & + & + & + \\
\hline Anxiety disorders & + & + & + \\
\hline Hopelessness & + & + & + \\
\hline Chronic physical illness & + & & + \\
\hline Negative life events & + & + & + \\
\hline Social support & low & & \\
\hline Childhood abuse and other experiences & & + & \\
\hline Parental psychopathology & & + & \\
\hline \multicolumn{4}{|l|}{ Suicidal behaviour in the past } \\
\hline Previous suicidal ideation & & + & + \\
\hline Previous suicide attempts & & + & + \\
\hline Family history of suicide & & + & + \\
\hline
\end{tabular}




\subsubsection{Risk factors for suicidal ideation}

Suicide research has mainly focused on suicide attempts and completed suicides and relatively few studies have focused on suicide ideation. Prior research suggests a variety of risk factors for suicide ideation. Thoughts of suicide appear to be unrelated to gender (Murray, 1973; Friedman et al., 1987; Sorenson \& Rutter, 1991), with exceptions (Paykel et al., 1974; Pages et al., 1997; Kessler et al., 2005) or educational attainment (Kinkel et al., 1988; Sorenson \& Rutter, 1991), (exception Kessler et al., 2005), but may be more prevalent among non-married / single and younger individuals (Sorenson \& Rutter, 1991; Zimmerman et al., 1995; Kessler et al., 2005). Also low self-esteem (de Man et al., 1992), limited probem-solving ability (Priester \& Clum, 1993; Dixon et al., 1994), hopelessness (Beck et al.,1979; Rudd, 1990; Rudd et al., 1993; Hintikka et al., 1998; Vilhjalmsson et al., 1998), dissatisfaction, pessimism, anxiety / anxiety disorders (Rudd et al., 1993; Vilhjalmsson et al., 1998; Sareen et al., 2005), mental illness, especially major depressive disorder (Paykel et al., 1974; Beck et al., 1979; Smith \& Crawford, 1986; Kinkel et al., 1988; Rudd, 1990; Kandel et al., 1991; Sorenson \& Rutter, 1991; Breslau, 1992; Rudd et al., 1993; Hintikka et al., 1998; Vilhjalmsson et al., 1998), as well as chronic pain or chronic conditions (Paykel et al., 1974; Breslau, 1992; Ingersoll et al., 1993; Vilhjalmsson et al., 1998), substance use disorder (Kinkel et al., 1988; Kandel et al., 1991; Murphy et al., 1992; Bartels et al., 1992; Burge et al., 1995; Pages et al., 1997; Vilhjalmsson et al., 1998), stress in general (Paykel et al., 1974; Kandel et al., 1991, de Man et al., 1992), negative life events (Paykel et al., 1974), family difficulties (Kandel et al., 1991), economical problems (Kandel et al. 1991; Vilhjalmsson et al., 1998; Kessler et al., 2005) and low social support (Paykel et al., 1974; Kinkel et al., 1988; Kandel et al., 1991; de Man et al., 1992) have been found to be associated with suicidal ideation. The most consistent factors identified as risk factors of suicidal ideation have been depression and hopelessness. These findings seem to be unrelated to geographic location or age of the population studied. (Table 1).

\subsection{Suicide attempt}

\subsubsection{Definition of suicide attempt}

Suicide attempt is defined as self-injurious behaviour with a non-fatal outcome accompanied by evidence (either explicit or implicit) that the person intented to die (American Psychiatric Association, 2003). According to Skegg (2005) attempted suicide as a term is used for episodes where there was at least some suicidal intent, or sometimes without reference to intent. On the other hand, deliberate self-harm is also used along suicide attempt. Deliberate self-harm is defined as willful self-inflicting of painful, destructive, or injurious acts, but without intent to die. Deliberate self-harm is used especially in the UK (American Psychiatrtic Association, 2003; Skegg, 2005). 


\subsubsection{Epidemiology of attempted suicide}

Official statistics on attempted suicide are not usually collected annually, as is the case for completed suicides, but several epidemiologic surveys have reported population-based estimates of lifetime prevalence of a suicide attempt (Paykel et al., 1974; Moscicki et al., 1988; Kessler et al., 1999; Weissman et al., 1999; Norlev et al., 2005). The estimates have ranged from $0.7 \%$ to $5.9 \%$. The 12 -month prevalences have ranged from $0.19 \%$ to $0.6 \%$ (Petronis et al., 1990; Kessler et al., 1999; 2005). In NCS and NCS-R Kessler et al. (1999; 2005) reported 12-month prevalences of suicide attempts as $0.4 \%$ and $0.6 \%$, respectively. Accordingly, this means that there are approximately 500 suicide attempters per 100000 population in the US each year.

As a part of the WHO/EURO Multicentre Study on Parasuicide, the rates of attempted suicide among persons aged 15 and over for the period 1989-1992 were reported. In Helsinki, Finland, the rate of attempted suicide for males was 314/100 000 and for females 246/ 100 000. With only one exception (Helsinki), the person-based suicide attempt rates were higher among females than males, approximately 2:1 (Schmidtke et al., 1996).

Suicide attempts are more common among the young people than the elderly, whereas completed suicide is more common among the elderly. Between $2 \%$ to $12 \%$ (median $6 \%$ ) of young people report a lifetime history of suicide attempt (Beutrais, 2002).

A suicide attempt is one of the strongest predictors of the subsequent suicide. The risk of suicide after an attempt is up to 40 times the expected rate (Harris \& Barraclough, 1997; Suominen et al., 2004a). In recent Finnish studies 5 to $8 \%$ of suicide attempters commited suicide during the follow-up period and the risk of suicide was highest during the first year following the index attempt (Ostamo \& Lönnqvist, 2001; Suokas et al., 2001; Suominen et al., 2004a; 2004b). Geographically suicide attempt rates in Finland among both sexes are higher in urban than in rural areas. Male rates are higher than female rates in almost every area under study, from south to north, east to west (Ostamo et al., 1991).

\subsubsection{Risk factors for attempted suicide}

Risk factors for attempted suicide have been the focus of numerous studies during the past decades. Psychiatric disorders, especially MDD, have been found in several studies to be a major risk factor (Suominen et al., 1996; Mann, 1999; Beautrais, 2001). Suominen et al. reported that at least one Axis I diagnosis was made in $98 \%$ of the suicide attempters, while over $70 \%$ of the cases suffered from depressive disorders and about 50\% from alcohol dependence or abuse (Suominen et al., 1996). The association between female gender and attempted suicide is also well known (Schmitdke et al., 1996; Beutrais, 2002). The other risk factors for attempted suicide listed extensively by Mann (1999), Beautrais (2001; 2002) and Skegg (2005) in their reports include demographic factors such as younger age, divorce, unemployment; such socioeconomic disadvantages, as low income, low educational 
status or poverty, social and familial factors such as childhood abuse or other adverse childhood experiences: parent's separation or divorce, parental psychopathology, social isolation; comorbid psychiatric illnesses, such as personality disorders, substance use disorders, or anxiety disorders ; hopelessness, fewer reasons for living, subjective suicidal ideation, higher lifetime rate for aggression and impulsivity, family/personal history of suicidal acts, recent stressful life events and prior outpatient psychiatric treatment. Some factors may also be of protective nature, such as religion, cultural norms or social support. Often risk factors and protective factors are interlinked (Skegg, 2005). The most consistent risk factor is the presence of a psychiatric disorder, most commonly depression, followed by substance abuse and anxiety disorders. (Table 1).

\subsection{Suicide}

\subsubsection{Definition of suicide}

Suicide is defined as self-inflicted death with evidence (either explicit or implicit) that the person intented to die (American Psychiatric Association, 2003).

\subsubsection{Epidemiology of suicide}

Suicide has become a major public health issue around the world. It is among the leading causes of death, and suicide accounts for more deaths than the number due to HIV infection and AIDS combined, or due to homicide and war combined. In Finland the suicide rate is among the highest in Europe (19.7/100 000 in 2004), although it is well worth noticing that there has been a $30 \%$ decline during the past 15 years (Figure 2). In USA, for example, the suicide rate is 13.9/100 000 (2002) and in Sweden 13.4 /100 000 (2001). The highest annual suicide rates are in Eastern Europe, especially in the Baltic countries and former Soviet republics (> 27/100 000) and the lowest in Latin American and Islamic countries $(<6.5 / 100000)$. Men have a higher rate of completed suicide than women, usually the male to female ratio is approximately 3-4:1 (World Health Organization, 2005). Because suicide is more open to cultural, ethnic and religious influences, the rates vary significantly among the various age groups, gender and different countries.

In psychological autopsy studies, most have found that over $90 \%$ of the suicide completers had a psychiatric disorder at the time of death, and approximately $60 \%$ of all suicides occur in persons with mood disorder (Mann, 2002). Propensity for lifetime mortality for suicide in discharged hospital population remains high, although in recent years there has been a downrating of the risk (Blair-West et al., 1999). Up to 50\% of the people who commit suicide are intoxicated at the time of death (Moscicki, 2001) and 11\% of completed suicides had a first-degree relative who had committed suicide (Maris, 2002). 
Figure 2. Suicide mortality in Finland 1990-2004

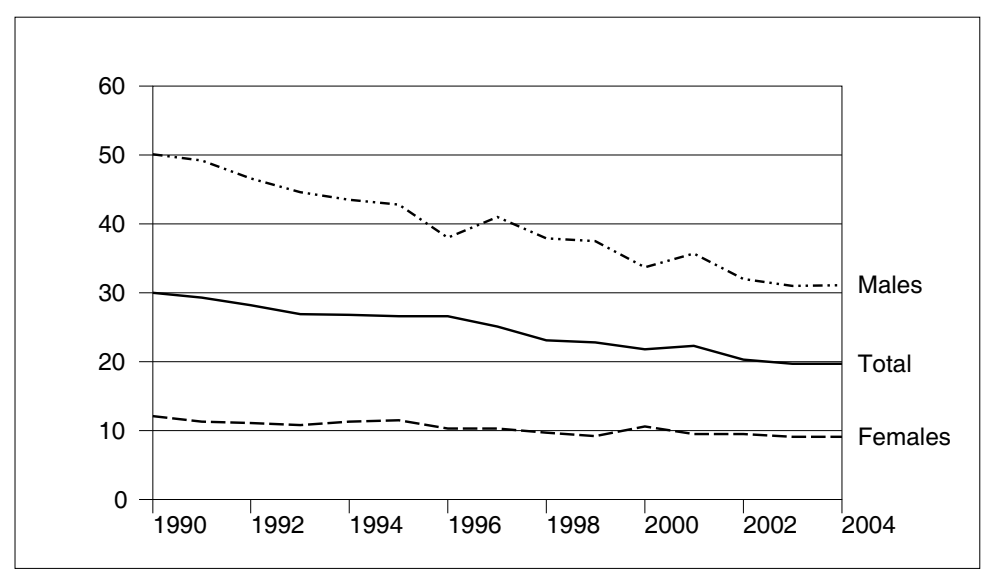

Vuosi

$\begin{array}{lllllllllllllll}1990 & 1991 & 1992 & 1993 & 1994 & 1995 & 1996 & 1997 & 1998 & 1999 & 2000 & 2001 & 2002 & 2003 & 2004\end{array}$

$\begin{array}{llllllllllllllll}\text { Males } & 50.1 & 49.2 & 46.6 & 44.6 & 43.5 & 42.8 & 38.0 & 41.0 & 37.9 & 37.5 & 33.7 & 35.7 & 32.0 & 31.0 & 31.1\end{array}$

$\begin{array}{llllllllllllllll}\text { Females } & 12.1 & 11.3 & 11.1 & 10.8 & 11.3 & 11.5 & 10.3 & 10.3 & 9.7 & 9.2 & 10.6 & 9.5 & 9.5 & 9.1 & 9.1\end{array}$

$\begin{array}{llllllllllllllll}\text { Total } & 30.0 & 29.3 & 28.2 & 26.9 & 26.8 & 26.6 & 26.6 & 25.1 & 23.1 & 22.8 & 21.8 & 22.3 & 20.3 & 19.7 & 19.7\end{array}$

\subsubsection{Risk factors for completed suicide}

Psychological autopsy is probably the most direct technique currently available for determining the relationship between particular risk factors and suicide (Isometsä, 2001; Cavanagh et al., 2003). Suicide has a strong association with psychiatric disorders. More than $90 \%$ of the suicide victims have a diagnosable psychiatric illness, usually MDD, alcohol dependence/abuse or personality disorder (Barraclough et al., 1974; Henriksson et al., 1993, Cheng, 1995; Cavanagh et al., 2003, Arsenault-Lapierre et al., 2004). The majority of suicide victims suffer from co-morbid mental disorders (Henriksson et al., 1993). Hopelessness, suicidal ideation and previous suicide attempts are strong and independent risk factors (Appleby et al., 1999; Brown et al., 2000; Beck, 2001). Those who have attempted suicide carry a risk of eventual suicide that is about 100 times greater than that of the general population during the year following the attempt (Hawton, 1987). The role of previous suicide attempts can be also seen as an indicator of future suicide risk. In their paper Joiner et al. (2003) discussed the fact that as suicidal ideation is related to subsequent completed suicide, a lifetime history of suicide attempts can lower the threshold of new attempts and thus, suicide related structures may become more easily triggered. Suicide attempt may be considered to be a better risk indicator for completed suicide than a risk factor expressing causality between an attempt and suicide. Male gender, advancing age, poor physical health, high intention of previous suicide attempts, being widowed/divorced/living alone, recent adverse life events, severe anxiety, chronic medical illness and family history of suicide are also known risk factors (Cheng, 1995; Vijayakumar \& Rajkumar, 1999; Suokas et al., 2001; Mann, 2002; Gaynes et al., 2004; Suominen et al., 2004a; 2004b). (Table 1). 


\subsection{Prevention of suicidal behaviour}

Primary prevention of suicide is the ideal method of protection. It requires broad modifications in social, economic and biological conditions to prevent certain members of a population from becoming suicidal. Primary prevention is directed at social interventions early in suicidal pathways. This approach forces interventions at the level of the environment and the means of self-destruction, rather than focusing on the individual at risk (Maris, 2002).

The prevention of suicidal ideation and suicide attempts serves ultimately as prevention of new suicides.

Primary preventive measures or protective factors could include reduction of divorce rates and violence (especially in families), restricting access to lethal methods (firearms, pesticides, toxic gas, barbiturates etc.), promoting physical health, proper exercise, diet, sleep etc. (Maris, 2002; Mann et al., 2005). Public education campaigns are popular and they increase knowledge and improve attitudes toward mental illness and suicide, but measures for suicide prevention have been insufficient (Mann et al., 2005).

As secondary prevention options (e.g. when members of population become suicidal), probably the best protective measures are early detection of suicidal individuals, accurate diagnosis and effective treatment of psychiatric disorders (especially MDD). Suicide prevention at this stage is possible because of completed suicides at least $83 \%$ had had contact with a primary care physician within a year of their death, and up to $66 \%$ within a month (Andersen et al., 2000; Luoma et al., 2002). Therefore, improving a physician's recognition of depression and suicide risk evaluation is a significant component of suicide prevention. Several studies examining suicidal behaviour in response to primary care education programs, mostly targeting on depression recognition and treatment, have all reported positive results (Mann et al., 2005). From pharmacological treatment forms for example lithium is effective in the prevention of suicide, deliberate self-harm, and death from all causes in patients with mood disorders (Cipriani et al., 2006). Thus, physician education in depression recognition and treatment is probably the most plausible method of secondary suicide prevention.

Recently many studies have used the method of population attributable risk (PAR) statistics, which measures the proportion of the condition that can be associated with exposure to a risk factor, or the proportion of the condition that would be eliminated if the risk factor were not present. Beautrais reported that the elimination of mood disorders would result in an $80 \%$ reduction in the risk of serious suicide attempt and $37 \%$ to $46 \%$ reduction in suicide rates (Beautrais et al., 1996; 1999). Similarily Pirkis et al. (2000) and Goldney et al. $(2000 ; 2003)$ reported 39\% to 57\% reduction for suicidal ideation and $40 \%$ for attempted suicide. 
Given the rarity of completed suicides, health care services have to acknowledge that many patients may need to be targeted in order to prevent few suicides. However, the components of suicide prevention, such as increased clinical supervision, encouragement of compliance/adherence, and improved patient management, will result in improved medical care for severely ill patients (Appleby et al., 2005).

Persons with a history of admission to a psychiatric hospital were at high risk of suicide, and the suicide risk peaks during periods immediately after admission or discharge. Suicide risk is significantly higher in patients who received less than the median duration of hospital treatment (Qin \& Nordentoft, 2005). The risk of suicide among patients incapacitated for one year or less after first admission increases significantly in the first year after discharge, according to Danish studies (Mortensen et al., 2000; Höyer et al., 2000).

\section{Figure 3. Targets of Suicide Prevention Interventions}

SUICIDAL BEHAVIOR

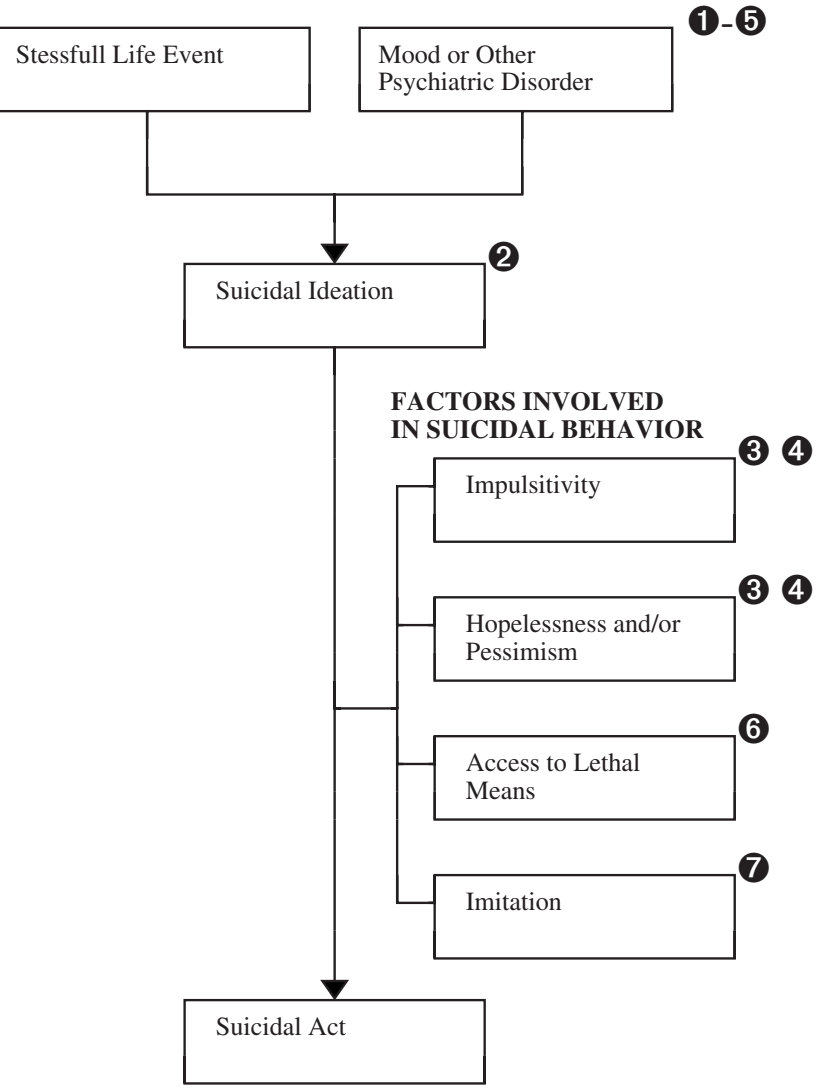

PREVENTION INTERVENTIONS

(1) Education and Awareness Programs Primary Care Physicians General Public

Community or Organizational Gatekeeperr

(2) Screening for Individuals at High Risk

Treatment

(3) Pharmacotherapy Antidepressants, Including Selective Serotonin Reuptake Inhibitors Antipsychotics

(4) Psychotherapy Alcoholism Programs Cognitive Behavioral Therapy

5 Follow-up Care for Suicide Attempts

6 Restriction of Access to Lethal Means

(7) Media Reporting Guidelines for Suicide

Mann, J. J. et al. JAMA 2005;294:2064-2074.

(Reprint with permission of JAMA) 


\subsection{Major depressive disorder (MDD)}

Depression is a common mental disorder characterized by sadness, loss of interest in activities and diminished energy. Depression is differentiated from normal mood changes by the extent of its severity, the symptoms and the duration of the disorder.

Major depressive disorder, in particular, is highly prevalent, aetilogically multifactorial, clinically heterogeneous, frequently follows a recurrent or chronic course, and significantly impairs the quality of life. MDD is among the leading cause of burden among all diseases and the leading cause of years lost due to disability (YLDs) in 2000 (Murray \& Lopez, 1996).

\subsubsection{Diagnosis of MDD}

The diagnostic classifications currently in use are the DSM (American Psychiatric Association, 1987; 1994; 2000) and the International Statistical Classification of Diseases and Related Health Problems (ICD) (World Health Organization, 1992; 1993; Tautiluokitus 1996).

In DSM-IV, unipolar forms of primary mood disorders are classified into three groups: MDD, dysthymic disorder, and depression not otherwise specified. MDD is characterized by one or more major depressive episodes (MDEs) lasting at least two weeks. Earlier DSM-III-R used term 'major depression' (MD) for MDD. However, diagnostic criteria remained the same. At least five symptoms are present during the same 2-week period and represent a change from one's previous functioning; in order to fulfill the criteria for MDD at least one of the symptoms is either 1) persistent depressed mood or 2) loss of interest or pleasure, which is accompanied by at least four of the following symptoms (total of five symptoms): significant weight change, insomnia or hypersomnia, psychomotor agitation or retardation, fatigue or loss of energy, feeling of worthlessness or excessive or inappropriate guilt, diminished ability to think or concentrate or indecisiveness, recurrent thoughts of death, suicidal ideation, or suicide attempt, (American Psychiatric Association 1987; 1994, 2000). Based on the number of criteria symptoms, the severity of symptoms, and the degree of disability, an episode of MDD may be classified as mild, moderate, or severe. The symptoms should not be the result of a direct physiological effect of a substance or a general medical condition or bereavement.

With ICD-10, the diagnosis of MDD is basically similar to the DSM-IV. Still, ICD-10 requires one symptom less than DSM-IV for diagnosis, fatigue or loss of energy is included in core symptoms with persistent depressed mood and loss of interest or pleasure, and feelings of worthlessness or inappropriate guilt is split into two symptoms. Research programmes usually apply the DSM classification. ICD-10 is in clinical use in Finland.

In this thesis, unless otherwise specified, depression refers to unipolar DSM-IV MDD. 


\subsubsection{Epidemiology of MDD}

The prevalence of depressive disorders in the general population has been estimated in numerous epidemiological studies and surveys around the world (WHO World Mental Health Survey Consortium 2004). Various epidemiological studies show that depression, compared with other medical diagnoses, is highly prevalent in the general population (Jenkins et al., 1997; Kessler et al., 1994; 2003; Jacobi et al., 2004). It is estimated that during their lifetime, approximately one fifth of the population will experience an episode of MDD (Kessler et al., 1994). It occurs twice as frequently in women than in men, can begin at any age, but on average the age of onset is in the mid-20's (Kessler et al., 2003).

In Epidemiological Catchment Area (ECA) study the prevalence estimates of MDD were 3.0\% for a current and $5.2 \%$ for lifetime disorder. In NCS and later NCS-R, Kessler et al. (1994; 2003) reported a lifetime prevalence of MDD of $14.9 \%$ and $16.2 \%$ and a 12-month prevalence of $8.6 \%$ and $6.6 \%$, respectively, in the population of US. Recently, in another large study, the National Epidemiologic Survey on Alcohol and Related Conditions (NESARC), Hasin et al. (2005) reported the prevalence of lifetime DSM-IV MDD of 13.2\% and 12-month prevalence of $5.3 \%$.

In the Netherlands Mental Health Survey and Incidence Study (NEMESIS) Bijl et al. (1998) reported the lifetime prevalence of DSM-III-R major depression to be $15.4 \%$ and 12-month prevalence of $5.8 \%$ in a Dutch population, and recently, in a large European multi-centred study (ESEMed) of Belgium, France, Germany, Italy, the Netherlands and Spain the prevalences were $12.8 \%$ and $3.9 \%$, respectively (Alonso et al., 2004). Wittchen and Jacobi (2005) analysed in their study the results of 17 European studies and found out that estimates for 12-month prevalence of MDD range from $3.1 \%$ to $10.1 \%$, with the median being $6.9 \%$.

In a recent Finnish study Pirkola et al. (2005) reported a 12-month prevalence of MDD of $4.9 \%$ based on the Health 2000 study, while in a Finnish Health Care Survey (FINHCS) Lindeman et al. (2000) found the 12-month prevalence of MDE to be $9.3 \%$. The difference in the prevalence may be explained by the diagnostic interview (M-CIDI) used with its stringent exclusion criteria in recent Health 2000 study (Pirkola et al., 2005).

In the Mini Finland Health Survey, Lehtinen \& Joukamaa (1994) reported that only one third of the persons suffering from clinically significant depression were actually being treated for their disorder. However, only about $50 \%$ of those with major depressive episode or dysthymia perceive need for mental health services (Isometsä et al., 1997). In FINHCS Hämäläinen et al. (2004) reported that only 59\% of those suffering from the severest major depression episodes use health services for depression. 


\subsubsection{Aetilogy of MDD}

MDD is a prototypical multifactorial disorder, aetilogically complex disorder (Kendler et al., 2002; 2006). An individual's risk of suffering an episode of MDD is influenced by factors from multiple domains, including genetic influences (Tsuang \& Faraone, 1990; McGuffin et al., 1996; Sullivan et al., 2000; Caspi et al., 2003; Korszun et al. 2004; Lesch, 2004), poor parenting/maternal stress during pregnancy/parental depression (Parker, 1979; Holmes \& Robins, 1988; Oates, 2002; O'Connor et al., 2002; Lyons-Ruth et al., 2002; Lieb et al., 2002), childhood sexual or physical abuse (Ferguson \& Mullen, 1999; Heim et al., 2000; Gladstone et al., 2004), premature parental loss (Tennant, 1988), predisposing personality traits (Angst \& Clayton, 1986; Hirschfeld et al., 1989; Boyce et al., 1991; Caspi et al., 1996; Kendler et al., 2004), early onset of an anxiety disorder (Breslau et al., 1995; Kessler et al., 1996; Young et al., 2004), low social support (Hendersson, 1992; Cooper \& Paykel, 1994), substance misuse (Kessler et al., 1996), marital difficulties (Whisman et al., 2000), a prior history of MDD (Lewinsohn et al., 1988; Harrington et al., 1990), and recent stressful life events (Paykel et al., 1969; Brown \& Harris, 1978; Kessler, 1997; Kendler et al., 2004). Some of these aetilogical factors have also been shown to interact. Caspi et al. (2003) reported gene-by-environment interaction, in which an individual's genetic makeup moderates his/her response to environmental factors. Individuals with one or two short allele of the 5-HTT promoter polymorphism exhibited more depressive symptoms, diagnosable depression and suicidality in relation to stressful life events than individuals homozygous for the long allele. Kendler et al. (2004) reported the interaction between life events and neuroticism, where neuroticism has a greater impact on MDD risk at high levels of adverse life events.

\subsubsection{Heritability of MDD}

Several studies have focused on the heritability of depression, and the estimates reported range from 20\% up to $70 \%$ (usually 20-45\%) (Sullivan et al., 2000; Wallace et al., 2002; Lesch, 2004). Sullivan et al. (2000) reported strong evidence for an association between MDD in the proband and MDD in the first-degree relatives (OR 2.84). Major depression is a familial disorder and its familiality mostly or entirely results from genetic influences. Recently, Kendler et al. (2006a) found heritability of MDD higher in women (42\%) than in men (29\%). However, heritability is always related to a specific population.

\subsubsection{Developmental factors of MDD}

MDD is a disorder with many aetilogic variables that are interrelated through developmental pathways. Kendler et al. (2002; 2006b) have constructed a developmental model for MDD in women and in men. They created a model to predict depressive episodes in the year before the most recent interview. Eighteen risk factors conceptualized as five developmental tiers reflecting childhood (genetic risk, disturbed family environment, childhood sexual abuse, childhood parental loss), early adolescence (neuroticism, 
self-esteem, early onset of anxiety and conduct disorder), late adolescence (educational attainment, lifetime traumas, social support, substance misuse), adulthood (history of divorce, past history of depression), and the preceding year (marital problems, difficulties, stressful life events). The overall results suggest that the development of MDD for both men and women results from the interaction of internalizing/externalizing symptoms and adversity. Childhood loss and low self-esteem were more potent variables in the model for men than in women. Also genetic risk factors seemed to have a broader spectrum of impact in men than in women, but from an aetilogic perspective, major depression is largely the same disorder in men and women.

\subsubsection{Course and outcome of MDD}

The data reported on the duration of an episode of MDD has varied in different studies, depending on the specific study, the population concerned and methodology used. Eaton et al. (1997) reported a duration of MDE of twelve weeks from the ECA, Spijker et al. (2002) reported median duration of three months from the NEMESIS study, and Kessler et al. (2003) sixteen weeks from NCS-R. Recently Hasin et al. reported a median duration for MDE to be 24 weeks in the general adult US population (Hasin et al., 2005). Hämäläinen et al. (2004) studied other median durations of the episodes and reported 4 weeks for mild episode, 5 weeks for a moderate one and 9 weeks for severe major depressive episode. The duration of an MDE was also associated with the severity of depression. Longer duration and greater severity of MDD are related to the referral to health services and psychiatric care. The severity of the depression and longer duration of MDE before treatment predict a longer episode of MDE (Melartin et al., 2004).

MDD is a chronic disorder and has a high risk of recurrence. Significant numbers of people (up to $80 \%$ ) who have experienced MDD will experience at least one more episode of MDD later during their lifetime, and 20\% will have a chronic course of MDE lasting more than 2 years (Angst, 1986; Keller et al., 1992; Brodaty et al., 2001).

\subsubsection{Comorbidity of MDD}

Comorbidity is defined as the occurrence of two or more disorders in a person in a defined period of time (Klerman, 1990). Comorbidity in depression has been the topic of numerous studies over the years. Comorbid MDD is so common that it is almost exceptional not to have a comorbid disorder in connection with MDD (Kessler et al., 1996). MDD patients have generally at least one comorbid Axis I disorder (Placidi et al., 2000, Melartin et al., 2002; 2004; Merikangas et al., 2003; Alonso et al., 2004; Hasin et al., 2005; Vuorilehto et al., 2005). In NCS-R, over 70\% of lifetime and almost $80 \%$ of 12 -month MDD patients, had at least one comorbid disorder, including 59\% with anxiety disorder, $24 \%$ with substance use disorder and 30\% with impulse control disorder (Kessler et al., 2003).

Only a few studies have assessed Axis II comorbidity in MDD in the same population. In a European multicentred study Casey et al. (2004) found the overall prevalence of 
personality disorders to be $22 \%$ in a community sample with depressive disorders, while Hasin et al. (2005) reported in their recent study a prevalence of $38 \%$ for any personality disorder. The most common disorders were obsessive-compulsive, paranoid, schizoid and avoidant personality disorder.

\subsubsection{Treatment of MDD}

During the last decade several sets of evidence-based treatment guidelines have been published in order to improve the detection and treatment of MDD. These guidelines cover the priciples and goals of psychiatric management with psychotherapeutic approaches, pharmacotherapy (antidepressant medications), combination of psychotherapy and medication, ECT, bright light therapy, among others (Schulberg et al., 1998; Crismon et al., 1999; Anderson et al., 2000; APA, 2000; Bauer et al. 2002; Suomen Psykiatriyhdistys, 2004; National Institute of Clinical Excellence, 2004). Other available forms of treatment for MDD include antipsychotic drugs and mood stabilizers, especially in combination with antidepressants (Mann, 2005, Wijkstra et al., 2005), exercise (Ernst et al., 2006), sleep deprivation (Tsuno et al., 2005), ethyl-eicosapentaenoic acid (EPA) (Parker et al., 2006) and hopefully in the future transcranial magnetic stimulation (TMS), deep brain stimulation (DBS) and vagus nerve stimulation (VNS) (Eltan \& Lerer, 2006). The most used treatments in Finland are antidepressant treatment, psychotherapy and ECT.

\subsubsection{Antidepressant treatment}

The pharmacotherapy of depression can be divided into three phases: acute, continuation and maintenance treatment. In the acute phase, the aim of the treatment is full remission, in the continuation phase, the prevention of relapse, and in the maintenance phase, it is the prevention of recurrence (Suomen Psykiatriyhdistys, 2004).

Depression can be effectively treated with antidepressants. Antidepressant pharmacotherapy is more important the more severe the depression is, and always indicated if depression is severe or psychotic. In mild or moderate cases of depression, effective psychotherapy, alone or combined with pharmacotherapy, are possible alternative treatments (Suomen Psykiatriyhdistys, 2004). As the effectiveness of available antidepressants is comparable, the selection of medication will be based on the side-effect profile, the safety and tolerability, interaction, and the patient's preference. Antidepressant doses must comply with treatment guidelines (American Psychiatric Association, 2000; Suomen Psykiatriyhdistys, 2004). The effect size of antidepressive medication in depression ranges from 0.51 to 1.09 (Khan et al., 2004, DeRubeis et al., 2005).

Antidepressant treatment should be maintained in the continuation phase for approximately four to nine months after remission, in order to prevent relapse. Long-term maintenance treatment should be considered to prevent recurrences (American Psychiatric Association, 2000; Suomen Psykiatriyhdistys, 2004). There are several factors that need to be considered in the decision whether or not to use maintenance treatment. These factors 
include the risk of recurrence (number of prior episodes, presence of comorbid conditions, residual symptoms between episodes), severity of the episodes (presence of suicidality, psychotic features or severe functional impairments), possible side-effects experienced and patient preferences (APA, 2000).

\subsubsection{Psychotherapeutic treatment}

In the treatment of depression, the aim of psychotherapeutic treatments is to alleviate depression by influencing the psychological and behavioural factors that induce and maintain depression. Psychotherapy that can be applied in the treatment of depression include cognitive or cognitive-behavioural therapy (CBT), interpersonal psychotherapy (IPT), brief psychodynamic psychotherapy, and cognitive problem-solving therapy. In acute phase of mild or moderate depression, psychotherapy can be used either alone, or combined with pharmacotherapy. In the continuation and maintenance phases, treatment of residual symptoms by psychotherapeutic means can be useful in order to prevent recurrence (Suomen Psykiatriyhdistys, 2004). The effect size of CBT has been reported to be from 0.44 to 0.68 (DeRubeis et al., 2005, Haby et al., 2006)

\subsubsection{Electroconvulsive Therapy (ECT)}

ECT has been used as a treatment for mental disorders since the 1930s. ECT is one of the most controversial treatments in public opinion and media. There is evidence that it is an effective treatment for psychotic and severe depression, and should be used if pharmacotherapy has not been effective, or rapid response is otherwise necessary (e.g. due to acute severe suicidality). ECT is an effective short-term treatment for patients with major depressive disorder, bilateral ECT moderately more effective than unilateral and high dose ECT is more effective than low dose (The UK ECT Review Group, 2003). Earlier research indicates that ECT is at least as effective (or probably more) as antidepressant medication for the treatment of major depression (SES -0.80, 95\% CI -1.29 to -0.29 ) (Weiner, 1994; UK ECT Review Group, 2003); nonetheless, ECT is used only rarely as a first-line treatment (American Psychiatric Association, 2000).

\subsubsection{Adherence and attitudes to treatment}

There is a variety of terminology in literature relating to the degree to which a patient follows treatment regimen. It is suggested that the term adhererence is preferable, as it it puts greater emphasis on the role of the clinician in forming a therapeutic alliance, and on the active rather than the passive participation of the patient in this process (Lingam \& Scott, 2002). The term adherence is defined as "patient acceptance of recommended health behaviours" (Wright, 1993). Adherence is a major problem in the treatment of depression (Pampallona et al., 2002). The successful treatment of MDD requires close adherence to treatment plans. Those who continue therapy with their initial antidepressant are least likely to experience relapse or recurrence and those who discontinue using their antidepressant early are most likely to have relapse or recurrence 
(Melfi et al., 1998). Psychiatrists are encouraged to question their patients about their concerns about adherence. Patients with MDD may be poorly motivated, pessimistic about their chances of recovery with treatment, or careless with their wellbeing. Side effects may often lead to non-adherence (American Psychiatric Association, 2000). Adherence to treatment guidelines could be improved throughout the adjustment of antidepressant dosage, reduction of benzodiazepine prescriptions, enhanced use of ECT and wider use of interpersonal therapy (Schneider et al., 2005).

Methods used to measure non-adherence have ranged widely. Patient self-reporting is probably the most accurate method (Stephenson et al., 1993). Although it is affected by low sensitivity (about 50\%), it generally has high specifity (90\%) (Lingam \& Scott, 2002). The importance of patients' attitudes and health beliefs have been increasingly emphasized. Sirey et al. (2001) reported that patients' perception of the stigma of depression at the start of treatment was indicative of their subsequent medication adherence. Attitudes toward antidepressants directly affect the patient's willingness to continue on an extended course of treatment (Mitchell, 2006). Reported rates of non-adherance with antidepressant medication in depressive disorders range from 10 to $60 \%$ (median $40 \%$ ), and $42 \%$ of patients discontinue their antidepressant medication during the first 30 days and 72\% within 90 days (Lingam \& Scott, 2002; Olfson et al., 2006). Still, only $1-2 \%$ of all publications on the treatment of affective disorders have explored the factors associated with non-adherence, and thus there is a considerable lack of understanding the factors that predict adherence (Lingam \& Scott, 2002).

\subsection{Suicidal behaviour in MDD}

\subsubsection{Epidemiology of suicidal behaviour in MDD}

Numerous studies have documented an association between suicidal behavior - completed suicide, suicide attempt, and suicidal ideation - and MDD.

A well known meta-analysis (Harris \& Barraclough, 1997) and two nationwide studies from Scandinavia (Höyer et al., 2000; Ösby et al., 2001) indicate that an inpatient with MDD has about a 20 -fold risk of completed suicide. The risk of a non-fatal suicide attempt among patients with MDD is less precisely known, but is estimated to be about $40 \%$ after the first lifetime episode of MDD (Malone et al., 1995) and the rate of repetition of attempt within a year is approximately $25 \%$ (Brådvik, 2003).

Depending on the definition applied, the prevalence of suicidal ideation ranges from $47 \%$ to $69 \%$ in patients with MDD (Asnis et al., 1993; Bronisch \& Wittchen, 1994; Zisook et al., 1994). Various types of non-fatal suicidal behavior tend to be highly prevalent among patients with MDD, who also have a markedly increased risk of completed suicide, of which, non-fatal suicidal behavior is perhaps the most important risk indicator (Harris \& Barraclough, 1997). The main cause of increased mortality in depression is suicide. 
Findings from the psychological autopsy studies conducted over the past decades suggest that depression is evident in $29-88 \%$ of all suicides (Lönnqvist, 2000).

While the three types of suicidal behavior - ideation, suicide attempt and completed suicide - probably represent a continuum of self-harming behaviours (Beck, 1986; Smith \& Crawford, 1986; Bonner \& Rich, 1987; Diekstra, 1993; Vilhjalmsson et al., 1998; Hawton \& Van Heeringen, 2000; Beautrais, 2001), research on both types of non-fatal behavior contributes to suicide prevention. More than half $(52 \%)$ of subjects completing suicide in major depression die in their first attempt, yet many of these first-timers have made their intent known. Further, about half of MDD subjects completing suicide had attempted suicide at least once before (Isometsä et al., 1994). Therefore recognizing both suicidal ideation as well as suicide attempts as important risk indicators, is likely to improve sensitivity in predicting suicide risk; investigating the risk factors for both may also reveal more information about the particular risk factors for completed suicide.

Table 2. Risk factors for suicidal behaviour in major depressive disorder.

\begin{tabular}{|c|c|c|c|}
\hline Variable & Suicidal Ideation & Suicide Attempt & Completed Suicide \\
\hline Gender & female & & male \\
\hline Age & younger & younger & advancing \\
\hline Marital status & & marital isolation & \\
\hline Education & $+/-$ & low & \\
\hline Economical problems / unemployment & + & & \\
\hline Severity of MDD & + & + & + \\
\hline \multicolumn{4}{|l|}{ Comorbid psychiatric disorders } \\
\hline Personality disorders & + & + & + \\
\hline Substance Use Disorder & + & + & + \\
\hline Anxiety disorders & + & + & + \\
\hline Hopelessness & + & + & + \\
\hline Negative life events & + & + & \\
\hline Social support & low & & \\
\hline \multicolumn{4}{|l|}{ Suicidal behaviour in the past } \\
\hline Previous suicidal ideation & & + & + \\
\hline Previous suicide attempts & + & + & + \\
\hline Family history of suicide & & + & + \\
\hline
\end{tabular}

\subsubsection{Risk factors for suicidal ideation in MDD}

The studies that have investigated the risk factors of suicidal ideation in depression have consistently identified the severity of depression (Van Gastel et al., 1997; Pages et al., 1997; Alexopoulos et al., 1999), comorbid personality disorder (Van Gastel et al., 1997), comorbid alcohol dependence or abuse (Cornelius et al., 1995; Pages et al., 1997), comorbid anxiety disorder (Schaffer et al., 2000), female gender (Pages et al., 1997, Schaffer et al., 2000), age (Lynch et al., 1999), unemployment (Pages et al., 1997), life events (Monroe et al., 2001), poor social support (Alexopoulos et al., 1999), hopelessness (Rudd, 1990, Van Gastel et al., 1997, Pages et al., 1997) and previous suicide attempts (Alexopoulos et al., 1999) as risk factors for suicidal ideation in MDD. (Table 2). 


\subsubsection{Risk factors for suicide attempts in MDD}

Numerous studies on non-fatal suicidal behavior among depressed patients have largely focused on risk factors of suicide attempts. Those found to be important in several independent studies include a suicide attempt in the past (Avery \& Winokur, 1978; Corbitt et al., 1996), or in the family (Paykel et al., 1975; Crook et al., 1975; Linkowski et al., 1985; Roy, 1993b; Malone et al., 1995), high severity or early onset of depression (Bulik et al., 1990; Roy, 1993b; Malone et al., 2000), comorbid personality disorder (Paykel \& Dienelt, 1971; Friedman et al., 1983; Fyer et al., 1988; Corbitt et al., 1996; Van Gastel et al., 1997; Soloff et al., 2000), comorbid alcohol dependence or abuse (Bulik et al., 1990; Duggan et al.; 1991, Roy, 1993b), comorbid chronic physical illness (Duggan et al., 1991), younger age (Van Gastel et al., 1997; Castrogiovanni et al., 1998), marital isolation or discord (Crook et al., 1975; Bulik et al., 1990; Roy, 1993b), recent adverse life events (Paykel et al., 1975; Van Gastel et al., 1997), hopelessness (Rifai et al., 1994; Malone et al., 2000; Soloff et al., 2000) and, not unexpectedly, suicidal ideation (Bulik et al., 1990; Malone et al., 1995; 2000). However, it remains controversial whether or not comorbid anxiety disorders do, in fact, increase (Lepine et al., 1993) risk of a suicide attempt (Noyes, 1991; Friedman et al., 1992; Allgulander, 1994; Placidi et al., 2000). (Table 2).

\subsubsection{Risk factors for completed suicide in MDD}

The lifetime risk of a non-fatal suicide attempt among patients with MDD is estimated at about 40\% (Malone et al., 1995), and may be an important proxy outcome in the investigation of risk factors for suicide. In their review Harris \& Barraclough (1998) calculated that the combined causes of death-risk for all affective disorders were 1.7 times greater than expected. Every sixth death among individuals with affective disorder treated as psychiatric patients is caused by suicide (Lönnqvist, 2000). However, the often quoted rate of $15 \%$ of completed suicide among psychiatric patients with severe depressive disorders (Guze \& Robbins, 1970) has lately been debated and reassessed. Blair-West et al. (1999) reported a combined lifetime suicide risk in major depression patients of 3.4\% (7\% for males and $1 \%$ for females) and Bostwick \& Pankratz (2000) reported subsequently a lifetime risk of $8.6 \%$.

In several earlier studies, as risk factors for completed suicide in MDD have been identified to include among others: a history of previous suicide attempts (Fawcett et al., 1987, Nordström et al., 1995; Angst et al., 2005; Coryell \& Young, 2005), male sex (Modestin \& Kopp, 1988; Höyer et al., 2004), previous psychiatric hospitalizations (Modestin \& Kopp, 1988; Höyer et al., 2004; Coryell \& Young, 2005), hopelessness (Fawcett et al., 1987; Coryell \& Young, 2005), suicidal ideation (Fawcett et al., 1987; Coryell \& Young, 2005), comorbid substance use disorder (Fawcett et al., 1987; Dumais et al. 2005), comorbid personality disorder (especially Cluster B) (Hansen et al., 2003; Dumais et al. 2005), anxiety (Fawcett et al., 1987) and increasing age (Höyer et al., 2004). (Table 2). 


\subsubsection{Hopelessness and its relation to suicidal behaviour and MDD}

Since the 1970's Beck and colleagues among others have shown in their reports that hopelessness contributes to the relationship between depression and suicidal behaviour. They also introduced a special scale for measuring hopelessness. Cognitive research on suicide and risk prediction has developed a model of suicidal behaviour in which hopelessness is a key psychological variable. Hopelessness as it occurs in depressed patients, may be viewed as having characteristics pertaining to both state and trait. During depression, hopelessness escalates and then subsides over the course of illness (Beck et al., 1975; 1990; Beck \& Weishaar, 1990; Beck, 2005; Williams et al., 2005a).

\subsubsection{Limitations of earlier studies}

While studies often provide important insights into the risk factors of non-fatal forms of suicidal behaviour during depression, they also tend to have important limitations that compromise the generalizeability, or even at times the validity of the findings. With few exceptions (Duggan et al., 1991; Bronisch \& Hecht, 1992; Nordström et al., 1995; Alexopoulos et al., 1999; Lynch et al., 1999; Oquendo et al., 2002; Hansen et al., 2003), most of the available studies are cross-sectional, and are based on selected patient populations. Moreover, suicide attempters are often compared with non-attempters who may also have high levels of suicidal ideation. If ideation and attempts are assumed to share common risk factors, such a design feature weakens the study's ability to recognize risk factors. Several studies have been conducted exclusively within inpatient settings (Avery \& Winokur, 1978; Linkowski et al., 1985; Malone et al., 1995; 2000; Corbitt et al., 1996; Van Gastel et al., 1997; Pages et al., 1997; Alexopoulos et al., 1999; Soloff et al., 2000), or only outpatients (Monroe et al., 2001), or exclusively geriatric patients (Rifai et al., 1994; Alexopoulos et al., 1999; Lynch et al., 1999), have had small sample sizes (Slater \& Depue, 1981; Bulik et al., 1990; Duggan et al., 1991; Roy et al., 1993b; Bronisch \& Wittchen, 1994; Rifai et al, 1994; Malone et al., 1995; 2000; Lynch et al., 1999; Soloff et al., 2000; Monroe etal., 2001), or been retrospective (Avery \& Winokur, 1978; Schaffer et al., 2000) or have investigated populations with diagnostically mixed affective disorders (Fawcett et al., 1990; Nordström et al., 1995). Thus the generalizeability of their findings to other settings or populations, or their power to detect risk factors, may have been limited.

Van Gastel et al. investigated the risk factors common to both suicidal ideation and attempted suicide (Van Gastel et al., 1997). Furthermore, suicidal ideation has often been measured with only a single item from a depression symptom scale, such as HAM-D or BDI (Alexopoulos et al., 1999; Schaffer et al., 2000; Monroe et al., 2001). In fact, very few studies can claim to both have a representative utilized patient sample and rigorous methodology. Moreover, since the etiology of suicidal behaviour is known to be multifactorial (Mann, 1999), a broader range of explanatory variables, in addition to mere symptom measures, is desirable. For example, social support may protect against suicidal acts by providing a reason for living (Malone et al., 2000), even among deeply depressed patients. 


\section{AIMS OF THE STUDY}

This study investigated the risk factors of suicidal behaviour (suicidal ideation and suicide attempts) both cross-sectionally and prospectively, short-term course of suicidal ideation, treatments received, attitudes of and adherence to treatment of suicidal patients in a sample of 269 MDD patients.

The specific aims of the study were:

1. To examine the risk factors of suicidal ideation and suicide attempts, and to highlight any difference between the two, in a sample of MDD patients effectively representing psychiatric in- and outpatients in the city of Vantaa in Finland.

2. To investigate prospectively the risk factors of attempted suicide among psychiatric out- and inpatients with major depressive disorder (MDD) in the city of Vantaa, Finland.

3. To investigate prospectively the short-term course of suicidal ideation and the temporal relationship between suicidal ideation and depressive symptoms, level of hopelessness and level of anxiety symptoms among psychiatric patients with MDD.

4. To investigate treatment received and self-reported attitudes as well as adherence to treatment by comparing patients with or without suicidal ideation or attempts at baseline. 
Figure 4. Flow-chart of the sampling procedure in the VDS

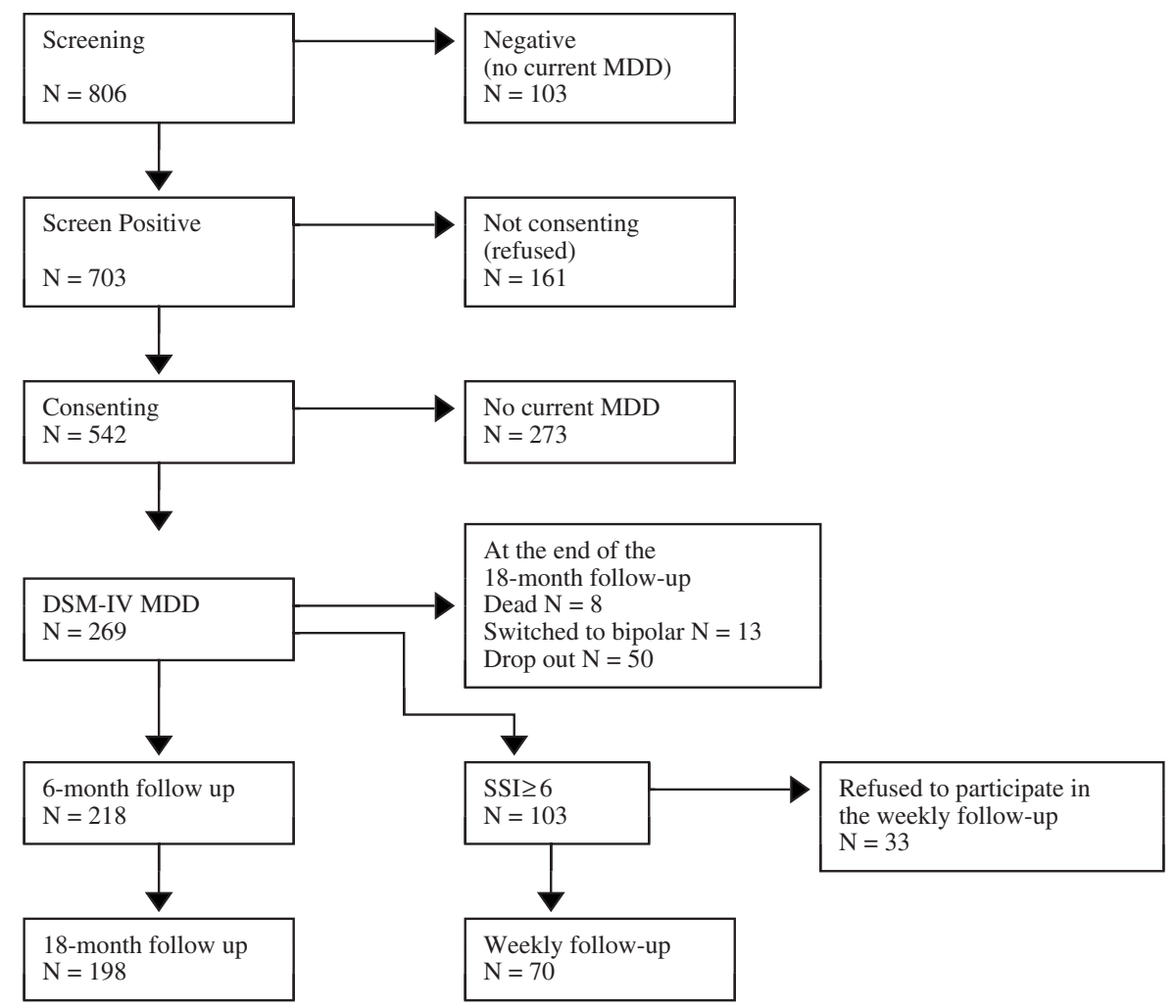

$\begin{array}{ll}\text { DSM-IV } & =\text { Diagnostic and Statistical Manual of Mental Disorders, } 4^{\text {th }} \text { edition } \\ \text { MDD } & =\text { Major Depressive Disorder } \\ \text { SSI } & =\text { Scale for Suicidal Ideation }\end{array}$ 


\section{MATERIALS AND METHODS}

\subsection{General study design}

The VDS is a collaborative depression research and development project conducted between the Department of Mental Health and Alcohol Research of the National Public Health Institute, Helsinki, and the Department of Psychiatry of HUCH, Peijas hospital (the Peijas Medical Care District PMCD), Vantaa, Finland. The catchment area comprises the city of Vantaa (population 169000 in 1997). The Department of Psychiatry at Peijas hospital offers secondary care psychiatric services to all Vantaa citizens. These include a psychiatric inpatient unit, a general hospital outpatient clinic, four community mental health care centres - each covering a specified catchment area - and two day hospitals.

\subsection{Screening}

The first phase of patient sampling for the VDS Cohort Study involved screening all patients in the PMCD for a possible new episode of DSM-IV MDD between February 1, 1997 and May 31, 1998. During that period, all patients ( $\mathrm{N}=806)$ aged 20-59 years, who were 1) seeking treatment at, 2) being referred to or 3) already receiving care and currently showing signs of deteriorating clinical state in the Department of Psychiatry, but without a clinical diagnosis of ICD-10 schizophrenia or bipolar I disorder, were screened for the presence of depressive symptoms. The screening instrument included the five screening questions regarding depression from the WHO Schedule for Clinical Assessment in Neuropsychiatry (SCAN), version 2.0 (Wing et al., 1990). The Scale for Suicidal Ideation (SSI) (Beck et al., 1979) was also completed in order to disclose the individuals with moderate to severe suicidal ideation or plans. If the following criteria matched the patients after either 1) a positive response to any of the SCAN screening questions, 2) clinical suspicion of depression by the interviewing personnel, or 3) a score of six or more $(\geq 6)$ in the SSI irrespective of any depressive symptoms, he/she was fully informed about the study project and his/her participation requested. Of the 703 eligible patients, $161(22.9 \%)$ declined to participate, but $542(77.1 \%)$ agreed and gave their written informed consent. The non-participating did not differ significantly $(\mathrm{p}>0.05)$ in age or gender from those who consented. The Ethics Committee of Peijas Hospital approved the study on December $2^{\text {nd }} 1996$. (Figure 4). 


\subsection{Baseline evaluation}

\subsubsection{Diagnostic measures}

In the second phase of sampling, the 542 consenting patients were interviewed face-toface by a researcher using the WHO SCAN, version 2.0, for which all had received training by a WHO certified training centre. Patients were examined whether or not the current mood episode fulfilled the criteria for (unipolar) DSM-IV MDD. All psychiatric and medical records in the PMCD, including a standardized set of laboratory tests, were also available at the interview. Patients with current alcohol or other substance abuse were interviewed after two or three weeks of abstinence, in order to eliminate substance-induced mood disorders. On this basis, 269 of the 542 patients participating in the second phase of sampling were diagnosed with DSM-IV MDD and were included in the study. Diagnostic reliability was verified using 20 videotaped diagnostic interviews; the kappa coefficient for MDD was 0.86[0.58-1.0], with 95\% observed agreement rate.

The decision to include the patient in the study cohort was made by the researcher during the interview, after which an entire SCAN interview was conducted to achieve a full picture of Axis I comorbid disorders. In addition, the Structured Clinical Interview for DSM-III-R personality Disorders (SCID-II) (Spitzer et al., 1989) was also used to assess diagnoses on Axis II.

\subsubsection{Exclusion criteria}

Patients with a diagnosis of DSM-IV bipolar I or II disorder, schizoaffective disorder, schizophrenia or another nonaffective psychosis, organic or substance-induced mood disorder, were excluded from the study, even if they fulfilled the symptom criteria of current MDE. Also excluded were the cases with a history of MDD if the current episode did not fulfil the criteria of the disorder.

\subsubsection{Observer and self-report scales}

In the cohort baseline measurements the following observer scales were used: the 17-item Hamilton Depression Rating Scale (HAM-D) (Hamilton, 1960) was used to assess the severity of depression, the Scale for Suicidal Ideation (SSI) for the severity of the suicidal ideation, the Social and Occupational Functioning Assessment Scale of DSM-IV (SOFAS) (Goldman et al., 1992) for the level of functioning.

The self-report scales used in the study included the 21-item Beck Depression Inventory (BDI) (Beck et al., 1961) for the severity of depression, Beck Anxiety Inventory (BAI) (Beck, 1988) for the level of anxiety, Beck Hopelessness Scale (HS) (Beck et al., 1974) 
for the level of hopelessness, Interview for Recent Life Events (IRLE) (Paykel, 1983) for life events and Perceived Social Support Scale-Revised (PSSS-R) (Blumenthal et al., 1987) for the level of social support.

\subsubsection{Suicidal behaviour}

Suicidal behaviour was investigated in several ways. Current suicidal ideation was first examined using the Scale for Suicidal Ideation (SSI). SSI is a 19-item observer scale designed to quantify the intensity of current conscious suicide ideation in various dimensions of self-destructive thoughts or wishes: the extent of the wish to die, the desire to make an actual suicide attempt and details of any plans; also internal deterrents to an active attempt, and subjective feelings of control and/or "courage" regarding a proposed attempt. Each item consists of three alternative statements graded in intensity from 0 to 2 , with the maximum total score being 38 . Here suicidal ideation refers to patients who scored $\geq 6$ in the SSI (Beck \& Kovacs, 1979). Secondly, the interviewer asked the patient whether they seriously considered suicide at any point during the current major depressive episode.

In addition, the occurrence of a suicide attempt during the current major depressive episode was investigated, based on both the interview and psychiatric records. By definition, a suicide attempt had to involve at least some degree of intent to die; self-harm with no suicidal intention was not classified as a suicide attempt.

\subsubsection{Adequacy of treatment received}

During the acute phase of the index episode, the majority of patients (78\%) were receiving antidepressants at normal adult doses (Melartin et al., 2005). The adequacy of antidepressant dosage was defined as usual adult doses recommended in the APA Practice Guideline (American Psychiatric Association, 2000). Psychotherapeutic support comprised of regular appointments with a mental health professional with the aim to help the patient by discussing his or her own problems. The patients whose diagnosis switched to bipolar disorder during the follow-up $(13 / 269,[5 \%])$ were excluded from the analyses. The outcome of MDD and the comorbid disorders were investigated at 6-month follow-up by repeated SCAN, version 2.0 and SCID-II interviews, the observer- and self-report scales and medical and psychiatric records.

\subsubsection{Attitudes toward treatment}

Attitudes toward antidepressant and psychotherapeutic treatment were assessed separately through interviews and rated on a Likert scale according to the following items: patient (1) actively wants treatment, (2) passively accepts treatment, (3) has reservations about treatment, (4) has definite negative attitudes toward treatment, (5) could not answer. At 
the 6-month follow-up, patients were interviewed with scales according to the following items: attitudes toward treatment are (1) very positive, (2) positive, (3) neutral, (4) negative, (5) very negative, or (6) could not answer (Melartin et al., 2005).

\subsection{Follow-up procedure}

\subsubsection{Outcome measures and life-chart methodology}

Of the 269 subjects with current MDD initially included in the study, 198 were still alive at the end of the 18-month follow-up period, had remained unipolar and could be followed up (Melartin et al., 2004). The patients whose diagnosis switched to bipolar disorder during the follow-up $(13 / 269,[5 \%])$ were analysed separately.

The outcome of MDD and the comorbid disorders were investigated at 6 and 18 months by repeating SCAN, version 2.0 and SCID-II interviews, the observer- and self-report scales and medical and psychiatric records.

A detailed life chart was created with the duration after the baseline divided into three classes: a) state of full remission ( 0 of the 9 criteria symptoms for major depressive episode), b) partial remission (1-4/9 symptoms), and c) major depressive episode (5+/9 symptoms).

Two alternative definitions for duration of the index episode were used: the uninterrupted duration of the episode of major depressive episode-1) time with full MDE criteria, and time to the first onset of state of full remission that lasted at least two consecutive months-2) time to full remission (Melartin et al., 2004).

\subsubsection{Suicide attempts during the follow-up period}

Occurrence of a suicide attempt before the baseline interview and during the follow-up period was based on both the interview and the psychiatric records (Study II). By definition, a suicide attempt had to involve at least some degree of the intent to die; self-harm with no suicidal intention was not included. Patient months were calculated based on the life chart. Information on the deaths among all the 269 patients during the follow-up period was obtained from the official records from the Statistics of Finland.

For the validity of the results, it is essential to verify that there were no more suicidal patients among those dropping out than among those followed up. This did not seem to be the case. Patients who could not be not followed up did not differ significantly from the patients who were, in terms of suicide attempts before the index episode (18\% vs. $14 \%$ ), suicide attempt during the index episode ( $25 \%$ vs. $23 \%$ ), or suicidal ideation (38\% 
vs. 39\%). However, they were somewhat younger, were more often living alone, had a higher score on the EPI-neuroticism scale, and more often had a comorbid dysthymia (Melartin et al., 2004).

\subsubsection{Weekly follow-up of suicidal ideation and covariates}

A comprehensive evaluation of patients' suicidality was conducted on a weekly basis until suicidal ideation was resolved. Seventy of the 103 patients with current suicidal ideation at the baseline were followed up weekly, and the SSI, HS, BAI, and BDI scores were measured (Study III). We initially planned that the weekly observation would be discontinued once the patient received two consecutive zero scores in the SSI. However, this goal was perhaps overly optimistic, and thus, we subsequently decided to analyze the weekly observations after the first score of zero in the SSI. All patients were followed up from the baseline to at least two observations, with the maximum follow-up time being 26 weeks. For 47 patients suicidal ideation was resolved, 8 patients dropped out, and 15 patients were followed up for the maximum period.

Patients who could be followed up successfully, as compared with those who were not, had higher level of psychopathology, more anxiety disorders (46[66\%] vs. 13[39\%], $\left.\chi^{2}=6.349, \mathrm{df}=1, \mathrm{p}=0.018\right)$, more cluster B personality disorders $\left(19[27 \%]\right.$ vs. $2[6 \%], \chi^{2}=6.141$, $\mathrm{df}=1, \mathrm{p}=0.017$ ), higher level of hopelessness (12.6 \pm 4.7 vs. $10.5 \pm 4.8, \mathrm{~F}=4.083, \mathrm{df}=1, \mathrm{p}=0.046)$.

\subsubsection{Prospective follow-up of treatment attitudes and adherence}

The first 6-month-period of the follow-up and the treatment of the index episode of the MDD were prospectively in focus when the attitudes and adherence of the patient were examined (Study IV). Of the 269 patients with current MDD initially included in the study, 218 were followed up and had remained unipolar at the 6-month follow-up.

Patients who could not be followed up did not differ from the patients who were followed up in terms of gender, patient status at the baseline (out- or inpatient), attitudes toward antidepressive medication or psychotherapy, prevalence of anxiety disorders, alcohol dependency/abuse, overall personality disorders, cluster $\mathrm{A}$ or $\mathrm{C}$ personality disorder, suicidal behaviour, the level of depression, hopelessness, functioning or

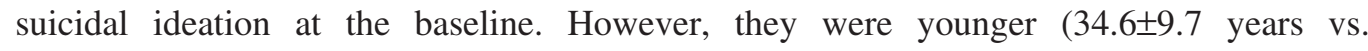
$40.8 \pm 11.0$ years, $\mathrm{F}=13.541, \mathrm{df}=1, \mathrm{p}<.001$ ANOVA), more often married or co-habiting [33/51(65\%) vs. $\left.101 / 218(46 \%), \chi^{2}=5.582, \mathrm{df}=1, \mathrm{p}=0.02\right]$, had more often cluster $\mathrm{B}$ personality disorder [12/51(24\%) vs. 27/218(12\%), $\left.\chi^{2}=4.141, \mathrm{p}=0.049\right]$, perceived less social support [PSSS-R score $35.8 \pm 12.3$ vs. $39.8 \pm 12.8, \mathrm{~F}=4.099, \mathrm{df}=1, \mathrm{p}=0.044$ ANOVA] and they received less antidepressive medication at the baseline $\left[17 / 48(35 \%)\right.$ vs. $189 / 218(87 \%), \chi^{2}=59.220$, $\mathrm{df}=1, \mathrm{p}<.001]$. 


\subsubsection{Self-reported treatment adherence}

Self-reported adherence concerning the provided treatments was investigated by interviewing patients at the 6-month follow-up using a Likert scale with the following response items: the patient has come to sessions/been on antidepressant treatment (1) regularly, treatment compliance adequate with respect to treatment goals, (2) somewhat irregularly and it is unclear whether this would affect treatment goals, (3) very irregularly, the treatment did not proceed according to plan, (4) not at all, the treatment could not be implemented (Melartin et al., 2005).

\subsubsection{Statistical analyses}

The t-test, chi square-test with Yates' continuity correction, Fisher's exact test, ANOVA, and the Kruskal-Wallis test were used in all four studies.

In the first study the statistical methods included non-parametric and parametric analyses. Post hoc subgroup differences were compared by using the Tukey HSD method. Multivariate nominal regression models were created, classifying suicidal behavior as the dependent variable into three mutually exclusive categories: non-suicidal patients (the reference group), suicidal ideators without suicide attempts, and suicide attempters. A variety of predetermined independent variables were included. Age and different rating scale scores were treated as continuous variables in all analyses unless otherwise mentioned. Variables not significantly associated with the independent variable in the multivariate nominal regression model were omitted from the final analysis. In order to avoid circularity, the suicidality items of the depression rating scales were omitted in nominal regression models, and the analysis were verified with and without these items.

In the second study, logistic regression models were created, classifying suicide attempt during the follow up as the dependent variable. The statistical methods also included the Mann-Whitney test to compare continuous variables not normally distributed.

In the third study, the decline of suicidal ideation was studied during the follow up with survival methods by defining the outcome as the first time when two consecutive zero measurements for SSI were found. The overall decline was displayed with the Kaplan-Meier survival curve. Cox's proportional hazard models with time-varying covariates were used to study the impact of reaching threshold levels in hopelessness, depression or anxiety scores prior to the decline of suicidal ideation while adjusting for the initial scores of suicidal ideation. For each measure, the appropriate threshold level was defined separately. The time-varying covariates representing the decline in hopelessness, depression or anxiety scores, were given the value 'one' if the corresponding threshold level $(\mathrm{BDI}<10, \mathrm{BAI}<10, \mathrm{HS}<9)$ was reached for the first time, and 'zero' before that. Sensitivity of the results was investigated by varying the chosen threshold values. Altered threshold values did not change the findings. The plausibility of the proportional 
hazards assumption was checked by plotting the logarithms of the cumulative baseline hazards against the follow up time in appropriate comparison groups, as well as with residual analyses of the models. Since the data was collected mostly from outpatients, there were some missed appointments and therefore, missing weekly measurements. The proportions of missing values were on average $32 \%$ for SSI, $21 \%$ for $\mathrm{HS}, 20 \%$ for BAI and $30 \%$ for BDI. Therefore, a more robust measure than the weekly scores of the covariates was needed in the analyses of decline.

In the fourth study, patients' attitudes and adherence to treatment at the baseline and at 6-month follow-up between the different groups of suicidal behaviour were compared. Suicidal behaviour was classified according three mutually exclusive categories: non-suicidal patients (the reference group), suicidal ideators without suicide attempts and suicide attempters, based on the suicidal behaviour manifesting at the baseline interview or preceding the index episode. To adjust for confounding differences in severity of major depression and other characteristics, such as gender, age, marital status, HS score, BAI score, alcohol dependency or abuse, PSSS-R score, SOFAS score and personality disorder (any, cluster A, B, or C), multinominal regression models were created. In these models, suicidal behaviour was set as the dependent variable, and possible confounding factors as well as attitudes and adherence to treatment served as independent factors. All non-significant factors were removed from the final analysis.

SPSS software, versions 9.0, 11.0 or 12.0.1 (SPSS Inc. 1989-2005), and Stata software (StataCorp LP) were used . 


\section{RESULTS}

\subsection{Suicidal ideation and attempts in MDD (Study I)}

\subsubsection{Clinical and demographic characteristics of the sample}

The characteristics of MDD patients without suicidal behaviour, and with suicidal ideation or suicide attempts, are presented in Table 3. Significant differences were found between the three groups in the degree of depression and suicidal ideation; prevalence of psychotic features, alcohol dependence or abuse, cluster B personality disorder, the degree of anxiety, hopelessness, social and occupational functioning and perceived social support. Furthermore, in post hoc subgroup comparisons, suicidal ideators were found to have a significantly higher level of depression (HAM-D, $p=0.005$; BDI, $p=0.001$ ) and hopelessness $(p<0.001)$, a lower level of perceived social support $(p<0.001)$ and functioning $(\mathrm{p}=0.004)$, they were more often males $(\mathrm{p}=0.02)$ and had alcohol dependence or abuse $(\mathrm{p}=0.01)$ more than the non-suicidal subjects. In addition, suicide attempters had a higher degree of depression (HAM-D, $p<0.001)$ and anxiety $(\mathrm{p}<0.001)$, lower level of functioning $(\mathrm{p}<0.001)$ and more alcohol dependence or abuse $(\mathrm{p}<0.001)$ than the suicidal ideators.

\subsubsection{Suicidal ideation and attempts during the current episode}

$58 \%$ of the patients reported suicidal ideation during the current episode, males more often than females (69 \% vs. 54\%; $\chi^{2}=5.109$, $\mathrm{df}=1, \mathrm{p}=0.02$ ). During the current depressive episode $15 \%$ of the patients had attempted suicide (13\% of males vs. $16 \%$ of females; $\left.\chi^{2}=0.572, \mathrm{df}=1, \mathrm{p}=0.449\right)$.

Among the 269 depressed patients 158 (59\%) had some suicidal behavior. Suicidal ideation according to the SSI (score $\geq 6$ ) was current in 103 patients $(38 \%)$, while $144(54 \%)$ reported suicidal ideation at some point during the current episode. Of the 41 (15\%) patients who had attempted suicide, only two $(5 \%)$ had done so without suicidal ideation at any stage of the current depressive episode (Figure 5).

\subsubsection{Risk factors for suicidal ideation or suicide attempt}

The nominal regression models predicting various types of suicidal behavior are presented in Table 4. The factors most strongly associated with suicidal ideation were high levels of hopelessness, alcohol dependence or abuse, low levels of functioning and poor perceived social support. Suicide attempt was associated with severity of MDD, alcohol dependence or abuse, younger age and low level of functioning. 
Table 3. Characteristics of patients with MDD according to suicidal behaviors.

\begin{tabular}{|c|c|c|c|c|}
\hline & $\begin{array}{l}\text { Non-suicidal } \\
\text { N }(\%)\end{array}$ & $\begin{array}{l}\text { Suicidal } \\
\text { Ideation } \\
\mathbf{N}(\%)\end{array}$ & $\begin{array}{l}\text { Suicide } \\
\text { Attempters } \\
\mathbf{N}(\%)\end{array}$ & $\begin{array}{l}\text { Total } \\
\text { N }(\%)\end{array}$ \\
\hline Overall & 111 & 117 & $41 \quad(15)$ & $269(100)$ \\
\hline $\begin{array}{l}\text { Sex } \\
\quad \text { Males }^{\mathrm{a}} \\
\text { Females }\end{array}$ & $\begin{array}{ll}22 & (20) \\
89 & (80)\end{array}$ & $\begin{array}{ll}41 & (35) \\
76 & (65)\end{array}$ & $\begin{array}{cc}9 & (22) \\
32 & (78)\end{array}$ & $\begin{array}{cc}72 & (27) \\
197 & (73)\end{array}$ \\
\hline Age, mean \pm sd & $40.5 \pm 11.4$ & $39.4 \pm 11.1$ & $37.8 \pm 10.0$ & $39.6 \pm 11.05$ \\
\hline $\begin{array}{l}\text { Psychotic } \\
\text { depression }^{b}\end{array}$ & $4 \quad(4)$ & $11 \quad(9)$ & $7 \quad(17)$ & $22 \quad(8)$ \\
\hline $\begin{array}{l}\text { HAM-D score, } \\
\text { mean } \pm \mathrm{sd}^{\mathrm{c}}\end{array}$ & $17.5 \pm 5.1$ & $19.8 \pm 6.0$ & $24.0 \pm 5.2$ & $19.5 \pm 5.9$ \\
\hline $\begin{array}{l}\text { SSI score, } \\
\text { mean } \pm \text { sd }^{d}\end{array}$ & $0.5 \pm 1.2$ & $9.0 \pm 7.6$ & $15.0 \pm 8.9$ & $6.4 \pm 8.1$ \\
\hline $\begin{array}{l}\text { BDI score, } \\
\text { mean } \pm \text { sd }^{\mathrm{e}}\end{array}$ & $25.4 \pm 8.3$ & $29.4 \pm 7.9$ & $29.1 \pm 10.0$ & $27.7 \pm 8.6$ \\
\hline $\begin{array}{l}\text { BAI score, } \\
\text { mean } \pm \mathrm{sd}^{\mathrm{f}}\end{array}$ & $20.2 \pm 10.4$ & $22.6 \pm 10.3$ & $27.5 \pm 10.5$ & $22.4 \pm 10.6$ \\
\hline $\begin{array}{l}\text { HS score, } \\
\text { mean } \pm \text { sd }^{g}\end{array}$ & $8.9 \pm 4.3$ & $11.3 \pm 4.9$ & $11.0 \pm 4.8$ & $10.3 \pm 4.8$ \\
\hline $\begin{array}{l}\text { Alcohol } \\
\text { dependence/ } \\
\text { abuse }\end{array}$ & $13 \quad(12)$ & $32 \quad(27)$ & $21 \quad(51)$ & $66 \quad(25)$ \\
\hline $\begin{array}{l}\text { Personality } \\
\text { disorder }\end{array}$ & $40 \quad(36)$ & $56 \quad(48)$ & $22 \quad(54)$ & 118 \\
\hline $\begin{array}{l}\text { Cluster A } \\
\text { Cluster B }^{\mathrm{i}} \\
\text { Cluster C }\end{array}$ & $\begin{array}{cl}16 & (14) \\
9 & (8) \\
27 & (24)\end{array}$ & $\begin{array}{ll}28 & (24) \\
18 & (15) \\
40 & (34)\end{array}$ & $\begin{array}{cc}7 & (17) \\
12 & (29) \\
18 & (44)\end{array}$ & $\begin{array}{ll}51 & (19) \\
39 & (15) \\
85 & (32)\end{array}$ \\
\hline $\begin{array}{l}\text { Anxiety } \\
\text { disorder }\end{array}$ & $61 \quad(55)$ & $61 \quad(52)$ & $30 \quad(73)$ & 152 (57) \\
\hline Smoking $^{j}$ & $42 \quad(38)$ & $48 \quad(41)$ & $25 \quad(61)$ & 115 \\
\hline $\begin{array}{l}\text { SOFAS score, } \\
\text { mean } \pm \mathrm{sd}^{\mathrm{k}}\end{array}$ & $55.2 \pm 9.7$ & $50.8 \pm 10.5$ & $45.5 \pm 11.8$ & $51.8 \pm 10.9$ \\
\hline $\begin{array}{l}\text { PSSS-R score, } \\
\text { mean } \pm \text { sd }^{1}\end{array}$ & $42.8 \pm 11.2$ & $36.3 \pm 13.1$ & $36.9 \pm 13.4$ & $39.1 \pm 12.7$ \\
\hline
\end{tabular}

$\chi^{2}=7.306, \mathrm{df}=2, \mathrm{p}=0.026$

$\chi^{2}=7.646, \mathrm{df}=2, \mathrm{p}=0.022$

HAM-D $=$ Hamilton Depression Rating Scale, $\mathrm{F}=21.67, \mathrm{p}<0.001$, ANOVA

SSI $=$ Scale for Suicidal Ideation, $\chi 2=119.13, \mathrm{df}=2, \mathrm{p}<0.001$, Kruskal Wallis test

$\mathrm{BDI}=$ Beck Depression Inventory, $\mathrm{F}=6.912, \mathrm{p}=0.001$, ANOVA

$\mathrm{BAI}=$ Beck Anxiety Inventory, $\mathrm{F}=7.4, \mathrm{p}=0.006$, ANOVA

$\mathrm{HS}=$ Beck Hopelessness Scale, $\mathrm{F}=7.920, \mathrm{p}<0.001$, ANOVA

$\chi 2=26,126, \mathrm{df}=2, \mathrm{p}<0.001$

$\chi 2=10.946, \mathrm{df}=2, \mathrm{p}=0.004$

$\chi 2=6.801, \mathrm{df}=2, \mathrm{p}=0.03$

SOFAS $=$ Social and Occupational Functioning Assessment Scale, $\mathrm{F}=14.006, \mathrm{p}<0.001$, ANOVA

PSSS-R $=$ Perceived Social Support Scale-Revised, $F=8.429, \mathrm{p}<0.001$, ANOVA 
Table 4. Nominal Regression Models for Different Suicidal Behaviours.

\begin{tabular}{|c|c|c|c|c|c|c|c|c|c|}
\hline \multirow[b]{2}{*}{ Variable } & \multirow{2}{*}{$\begin{array}{l}\text { Non-suicidal } \\
\text { OR }\end{array}$} & \multicolumn{2}{|c|}{ Suicidal Ideation } & \multirow[b]{2}{*}{ Wald } & \multirow[b]{2}{*}{ p } & \multicolumn{2}{|c|}{ Suicide Attempt } & \multirow[b]{2}{*}{ Wald } & \multirow[b]{2}{*}{$\mathbf{p}$} \\
\hline & & OR & $95 \% \mathrm{CI}$ & & & OR & $95 \% \mathrm{CI}$ & & \\
\hline Male sex & $(1.0)$ & 1.52 & $0.76-3.04$ & 1.421 & 0.23 & 1.34 & $0.47-3.87$ & 0.300 & 0.58 \\
\hline Age & $(1.0)$ & 0.98 & $0.95-1.00$ & 3.208 & 0.07 & 0.96 & $0.92-1.00$ & 3.789 & 0.052 \\
\hline HAM-D score & $(1.0)$ & 1.05 & $0.99-1.11$ & 2.571 & 0.10 & 1.16 & $1.06-1.27$ & 10.880 & 0.001 \\
\hline HS score & $(1.0)$ & 1.08 & $1.01-1.15$ & 5.149 & 0.02 & 1.06 & $0.97-1.16$ & 1.471 & 0.23 \\
\hline $\begin{array}{l}\text { Alcohol } \\
\text { dependence/abuse }\end{array}$ & $(1.0)$ & 2.19 & $1.01-4.74$ & 4.010 & 0.04 & 6.29 & $2.40-16.41$ & 14.097 & 0.001 \\
\hline PSSS-R score & $(1.0)$ & 0.97 & $0.95-1.00$ & 4.369 & 0.04 & 0.97 & $0.93-1.00$ & 2.698 & 0.10 \\
\hline SOFAS score & $(1.0)$ & 0.96 & 0.93-0.99 & 7.398 & 0.007 & 0.94 & $0.90-0.98$ & 8.653 & 0.003 \\
\hline
\end{tabular}

OR Odds Ratio

HAM-D Hamilton Depression Rating Scale

HS Beck Hopelessness Scale

PSSS-R Perceived Social Support Scale-Revised

SOFAS Social and Occupational Functioning Assessment Scale

Figure 5. Suicidal behavior among depressed patients $(N=269)$

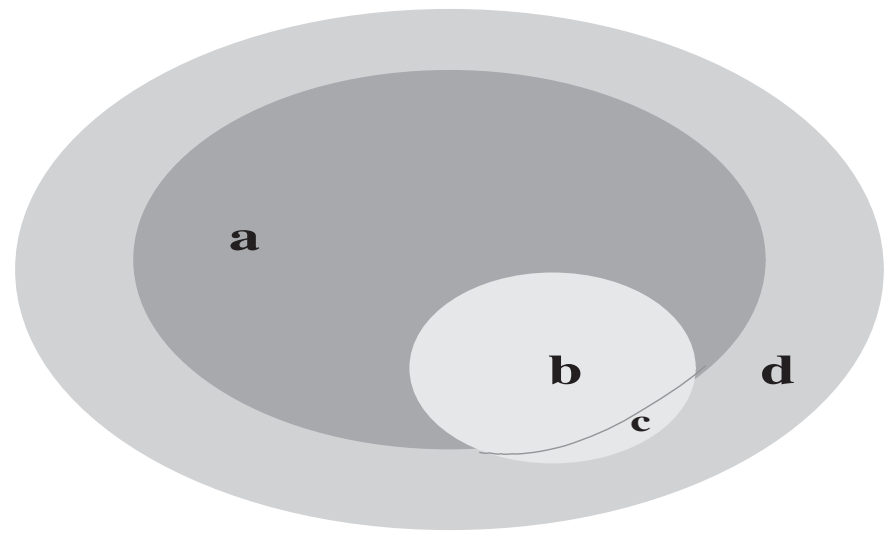

a Patients with suicidal ideation (156/269)

b Patients, who attempted suicide with suicidal ideation $(39 / 269)$

c Patients, who attempted suicide without suicidal ideation (2/269)

d Depressed patients without suicidal behavior (111/269) 


\subsection{Risk factors for attempted suicide in MDD (Study II)}

\subsubsection{Suicide attempts during the prospective follow-up}

During the 18-month prospective follow-up, $8 \%$ of the patients reported at least one, and altogether 41 discrete suicide attempts. The risk of a suicide attempt during full remission was 4/1201 patient months, during partial remission 12/1441 months (relative risk 2.50), and during MDE 25/995 months (relative risk 7.54, $\chi^{2}=24.3, \mathrm{df}=2, \mathrm{p}<0.001$ ). Of all the 269 patients in the cohort, eight patients (3\%) died during the 18 months after the baseline, three (1\%) of them through suicide.

\subsubsection{Differences between suicide attempters and non-attempters}

Significant differences were found between the attempters and non-attempters (Table 5) in terms of severity of index episode depression, the degree of suicidal ideation and anxiety, the prevalence of personality disorder, prevalence of suicide attempts during the index episode, time to full remission and total time spent in MDE, and marital status (lack of partner). Patients with cluster B or borderline personality disorder had more attempts (Mann-Whitney test, $\mathrm{Z}=-2.146, \mathrm{p}=0.032$ and $\mathrm{Z}=-2.165, \mathrm{p}=0.030$ respectively).

\subsubsection{Predictors of suicide attempt during the follow-up}

In the logistic regression model predicting suicide attempts during the follow-up period (Table 6), the predetermined covariates comprised gender, age, marital status, HAM-D score, alcohol dependence or abuse, BAI score, personality disorder (any), cluster B personality disorder, suicide attempt during the index episode, and time spent in MDEs (months). After removing the non-significant variables, three factors were strongly associated with suicide attempt: months spent in MDEs (OR 1.13), suicide attempt during the index episode (OR 5.62) and lack of partner (OR 5.10).

\subsubsection{Patients who switched to bipolar disorder}

Patients who switched to bipolar disorder (5\%) were a particularly suicidal subgroup. They reported more suicidal ideation before the index episode (69\% vs. 38\%; Fisher's exact test, $\mathrm{p}=0.039)$, had more suicide attempts before the index episode (62\% vs. $22 \%$; Fisher's exact test, $\mathrm{p}=0.003)$ and non-significantly during the follow-up (22\% vs. 8\%; Fisher's exact test, $\mathrm{p}=0.17$ ). 
Table 5. Differences in Characteristics Between Those Who Did and Did Not Attempt Suicide of the 198 Patients with Unipolar MDD during the 18-month Prospective Follow up.

\begin{tabular}{llllll}
\hline Characteristic & No SA & SA & All Patients & p \\
\hline Total N $(\%)$ & $182 \quad(92)$ & 16 & $(8)$ & $198 \quad(100)$
\end{tabular}

Sociodemographic features

Sex, $N(\%)$
Male
Female

Married or co-habiting ${ }^{\mathrm{a}}$

Age (years), mean \pm sd

PSSS-R score, mean \pm sd

Depression related characteristics

Severity of depression at baseline ${ }^{\mathrm{b}}$

Mild

Moderate

Severe

Psychotic features, $\mathrm{N}(\%)$

Melancholic features, $\mathrm{N}(\%)$

Time to full remission

(months), mean $\pm \mathrm{sd}^{\mathrm{c}}$

Total time in MDEs

(months), mean $\pm \mathrm{sd}^{\mathrm{d}}$

Symptom scores

HAM-D score, mean $\pm \mathrm{sd}^{\mathrm{e}}$

SSI score, mean $\pm \mathrm{sd}^{\mathrm{f}}$

BDI score, mean $\pm \mathrm{sd}^{\mathrm{g}}$

BAI score, mean $\pm \mathrm{sd}^{\mathrm{h}}$

HS score, mean $\pm \mathrm{sd}$

SOFAS score, mean \pm sd

History of suicidal behavior

SA during the index episode, $\mathrm{N}(\%)^{\mathrm{i}}$

SA before the index episode, $\mathrm{N}(\%)$

SA before/ during the index episode, $\mathrm{N}(\%)^{\mathrm{j}}$

\begin{tabular}{cccccc}
51 & $(28)$ & 4 & $(25)$ & 55 & $(28)$ \\
131 & $(72)$ & 12 & $(78)$ & 143 & $(72)$ \\
104 & $(57)$ & 3 & $(19)$ & 107 & $(54)$ \\
$41.2 \pm 11.0$ & $38.4 \pm 11.3$ & $41.0 \pm 11.1$ \\
$39.4 \pm 12.8$ & \multicolumn{3}{l}{$35.2 \pm 14.4$} & $39.0 \pm 13.0$
\end{tabular}

11 (6)

$99 \quad(54)$

$72 \quad(40)$

11 (6)

$67 \quad(37)$

$4.0 \pm 4.7$

$4.4 \pm 4.7$

$18.6 \pm 5.9$

$23.8 \pm 6.0$

$19.1 \pm 6.1$

$12.6 \pm 10.7$

$6.1 \pm 7.8$

$31.1 \pm 7.7$

$27.4 \pm 10.8$

$27.4 \pm 11.0$

$21.7 \pm 10.8$

$11.4 \pm 4.0$

$10.1 \pm 4.7$

$10.0 \pm 4.7$

$52.7 \pm 10.2 \quad 48.3 \pm 12.6 \quad 52.3 \pm 10.4$

$52.7 \pm 10.2 \quad 48.3 \pm 12.6 \quad 52.3 \pm 10.4$
.02

.002

.002

.001

.008

.057

.026

$\begin{array}{lllllll}21 & (11) & 7 & (44) & 28 & (14) & .003 \\ 42 & (23) & 4 & (25) & 46 & (23) & \\ 55 & (30) & 9 & (56) & 64 & (32) & .049\end{array}$




\begin{tabular}{|c|c|c|c|c|c|c|c|}
\hline Psychiatric comorbidity & \multicolumn{2}{|c|}{ No SA } & \multicolumn{2}{|l|}{ SA } & \multicolumn{2}{|c|}{ All Patients } & $\mathbf{p}$ \\
\hline Psychiatric comorbidity (any), N(\%) & 141 & $(78)$ & 13 & $(81)$ & 154 & $(78)$ & \\
\hline Alcohol dependence/abuse, $\mathrm{N}(\%)$ & 40 & $(22)$ & 4 & $(25)$ & 44 & $(22)$ & \\
\hline Alcohol dependence, $\mathrm{N}(\%)$ & 21 & (12) & 2 & (13) & 23 & (12) & \\
\hline Alcohol abuse, $\mathrm{N}(\%)$ & 19 & $(10)$ & 2 & (13) & 21 & (11) & \\
\hline Personality disorder (any), $\mathrm{N}(\%)^{\mathrm{k}}$ & 74 & $(41)$ & 11 & (69) & 85 & $(43)$ & .036 \\
\hline $\begin{array}{l}\text { Cluster A } \\
\text { Cluster B } \\
\text { Cluster C } \\
\text { BPD }\end{array}$ & $\begin{array}{l}32 \\
24 \\
54 \\
20\end{array}$ & $\begin{array}{l}(18) \\
(13) \\
(30) \\
(11)\end{array}$ & $\begin{array}{l}5 \\
4 \\
8 \\
3\end{array}$ & $\begin{array}{l}(31) \\
(25) \\
(50) \\
(20)\end{array}$ & $\begin{array}{l}37 \\
28 \\
62 \\
23\end{array}$ & $\begin{array}{l}(19) \\
(14) \\
(31) \\
(12)\end{array}$ & \\
\hline Anxiety disorder (any), N(\%) & 98 & $(54)$ & 10 & (63) & 108 & $(54)$ & \\
\hline $\begin{array}{l}\text { Panic disorder } \\
\text { Agoraphobia without panic } \\
\text { Social phobia } \\
\text { Simple phobia } \\
\text { GAD } \\
\text { OCD } \\
\text { PTSD }\end{array}$ & $\begin{array}{l}22 \\
20 \\
30 \\
43 \\
23 \\
9 \\
2\end{array}$ & $\begin{array}{l}(12) \\
(11) \\
(17) \\
(24) \\
(13) \\
(5) \\
(1)\end{array}$ & $\begin{array}{l}4 \\
2 \\
4 \\
7 \\
3 \\
- \\
-\end{array}$ & $\begin{array}{l}(25) \\
(13) \\
(25) \\
(44) \\
(19) \\
- \\
-\end{array}$ & $\begin{array}{l}26 \\
22 \\
34 \\
50 \\
26 \\
9 \\
2\end{array}$ & $\begin{array}{l}(13) \\
(11) \\
(17) \\
(25) \\
(13) \\
(4) \\
(1)\end{array}$ & \\
\hline
\end{tabular}

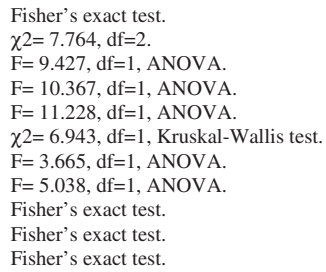

Abbreviations: ANOVA = analysis of variance, $\mathrm{BAI}=$ Beck Anxiety Inventory, BDI $=$ Beck Depression Inventory, $\mathrm{BPD}=$ borderline personality disorder, $\mathrm{GAD}=$ generalized anxiety disorder, HAM-D = Hamilton rating scale for Depression, HS = Beck Hopelessness scale, MDE = major depressive episode, $\mathrm{MDD}=$ major depressive disorder, $\mathrm{OCD}=$ obsessive-compulsive disorder, PSSS-R = Perceived Social Support Scale-Revised, PTSD = posttraumatic stress disorder, $\mathrm{SA}=$ suicide attempt, SOFAS $=$ Social and Occupational Functioning Assessment Scale, SSI = Scale for Suicidal Ideation .

Table 6. Logistic regression model for suicide attempts during the 18-month follow up. (N=198).

\begin{tabular}{lcccc}
\hline Variable & OR & $\mathbf{9 5 \%}$ CI & Wald $\chi^{\mathbf{2}}$ & $\mathbf{p}$ \\
\hline Female sex & 1.39 & $0.36-5.28$ & 0.228 & 0.63 \\
Age (years) & 0.97 & $0.92-1.03$ & 1.136 & 0.29 \\
Total time in MDE (months) & 1.13 & $1.03-1.26$ & 6.960 & 0.008 \\
Marital status (lack of partner) & 5.10 & $1.32-19.71$ & 5.589 & 0.01 \\
SA in the baseline & 5.62 & $1.69-18.61$ & 7.968 & 0.005 \\
\hline
\end{tabular}

Abbreviations: MDE- Major Depressive episode, SA- Suicide Attempt 


\subsection{Duration and trends of suicidal ideation and depression during the follow-up period (Study III)}

\subsubsection{Course of suicidal ideation}

Suicidal ideation resolved in two thirds $(67 \%)$ of the patients, but persisted for the entire follow-up in one fifth $(21 \%)$. In addition, $11 \%$ of the patients dropped out. $50 \%$ of the population reached zero in 2.2 months (9.6 weeks). The median time for reaching a zero level in the suicidal ideation was 1.6 months (6.8 weeks). For patients with both the weekly follow-up (duration of suicidal ideation) and the life chart (time with full MDE criteria and time to full remission) measures available $(n=53)$, the median time for the decline to zero was 2.7 months, the median time with full MDD criteria was 2.6 months and the median time to achieve full remission was 4.2 months, respectively. The difference in the median time for suicidal ideation decline was not statistically significant between patients with cluster B personality disorders and those without (1.7 months [7.4 weeks] vs. 1.6 months [6.7 weeks], $\mathrm{p}=0.45$, log rank test) (Figure 6).

\subsubsection{Baseline factors predicting duration of suicidal ideation}

Cox's proportional hazard models with time-varying covariates were used to study the effect of risk factors predicting the duration of suicidal ideation. A high baseline level of suicidal ideation, depressive symptoms, and the presence of any personality disorder each predicted a longer duration for suicidal ideation.

\subsubsection{Predictors for a decline in suicidal ideation}

In separate analyses, a decline in hopelessness, depressive symptoms and anxiety were each significant predictors for the decline in suicidal ideation. In all analyses, adjusting for the initial level of suicidal ideation showed that the decline depends significantly on the severity of the baseline symptoms; the higher the initial level, the longer the duration. The importance of the initial level of suicidal ideation was stable in all separate analyses.

When analysing the impact of a decline in hopelessness, depressive symptoms and anxiety symptoms jointly in the decline of suicidal ideation, the apparent separate effect of anxiety turned out to be non-significant (Table 7), whereas declines in both depression and hopelessness had independent effects on the decline in suicidal ideation. This may be due to the high correlation between subsequent scores in hopelessness and anxiety (0.8). Since the decline in hopelessness was more rapid in anxiety, it apparently masked the effect of the decline in anxiety. 
Table 7. Cox proportional hazard models for the decline of suicidal ideation adjusted separately for the normalization of depressive symptoms (BDI), anxiety (BAI), and hopelessness (HS) and jointly for all.

\begin{tabular}{|c|c|c|c|c|c|c|c|c|c|}
\hline \multirow[b]{2}{*}{ Variable } & \multirow[b]{2}{*}{ Depression } & \multirow[b]{2}{*}{$\mathbf{p}$} & \multicolumn{3}{|l|}{ Separate models } & \multirow[b]{2}{*}{$\mathbf{p}$} & \multicolumn{3}{|c|}{ Joint model } \\
\hline & & & $\begin{array}{l}\text { Anxiety } \\
\text { HR 95\% CI }\end{array}$ & $\mathbf{p}$ & $\begin{array}{l}\text { Hopelessness } \\
\text { HR } 95 \% \text { CI }\end{array}$ & & HR & 95\% CI & $\mathbf{p}$ \\
\hline SSI baseline & $\begin{array}{ll}0.91 & 0.84-0.97\end{array}$ & .008 & $0.92 \quad 0.86-0.99$ & .023 & $0.92 \quad 0.86-0.97$ & .02 & 0.90 & $0.84-0.97$ & .004 \\
\hline BDI & $7.68 \quad 3.73-15.85$ & $<.001$ & & & & & 5.74 & $2.69-12.25$ & $<.001$ \\
\hline BAI & & & $4.70 \quad 1.99-11.09$ & $<.001$ & & & 1.62 & $0.59-4.48$ & .34 \\
\hline HS & & & & & $5.90 \quad 2.24-15.52$ & $<.001$ & 3.51 & $1.15-10.73$ & .03 \\
\hline
\end{tabular}

Abbreviations: SSI = Scale for Suicide Ideation, BDI = Beck Depression Inventory, BAI = Beck Anxiety Inventory, HS = Beck Hopelessness Scale, HR= Hazard Ratio.

Figure 6. Decline in proportion of cases with suicidal ideation by the Kaplan-Meier survival curve.

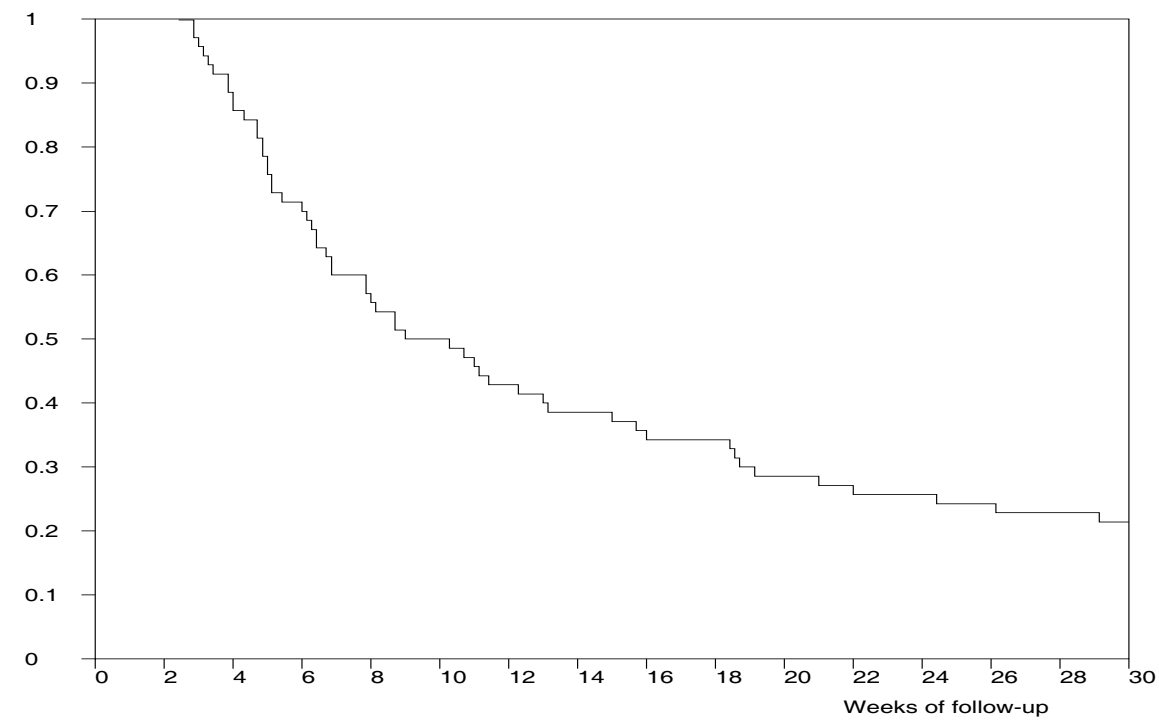




\subsection{Adequacy, attitudes and adherence to treatments (Study IV)}

\subsubsection{Differences between clinical characteristics and treatment}

Patients with suicidal behaviour had a higher level of overall psychopathology on entering the study. Their level of depression, anxiety, hopelessness and suicidal ideation were all significantly higher. They had also a higher prevalence of alcohol dependency/abuse, cluster B personality disorders and any comorbidity overall. The prevalence of MDD, the level of depressive symptoms, anxiety and suicidal ideation of patients with suicidal behaviour remained higher at follow-up.

Suicidal patients received significantly more often antidepressant and anxiolytic treatment, they visited their psychiatrist significantly more often and the number of overall visits was also greater than non-suicidal patients. (Table 8). Patients with suicidal behaviour appeared to receive treatment to correspond to their condition.

\subsubsection{Attitudes and self-reported adherence to treatment}

Patients with suicidal behaviour had a more favourable attitude to antidepressant treatment both at the baseline and at the 6-month follow-up. There were no statistically significant differences in the attitudes toward psychotherapeutic treatment. After adjusting for the confounding effect of the level of depression and other possible factors, the positive attitudes toward antidepressant treatment remained still significantly associated with both kinds of suicidal behaviour. However, despite the more positive attitudes, self reported adherence to antidepressant and psychotherapeutic treatment did not differ between the groups (Table 9). 
Table 8. Treatment during the six-months follow-up.

\begin{tabular}{|c|c|c|c|c|c|c|c|c|}
\hline & $\begin{array}{l}\mathbf{N S} \\
\mathbf{N}\end{array}$ & $(\%)$ & $\begin{array}{l}\mathbf{S I} \\
\mathbf{N}\end{array}$ & $(\%)$ & $\begin{array}{l}\text { SA } \\
\mathbf{N}\end{array}$ & $(\%)$ & $\begin{array}{l}\text { Total } \\
\mathbf{N}\end{array}$ & $(\%)$ \\
\hline Overall & 92 & $(42)$ & 92 & $(42)$ & 34 & (16) & 218 & $(100)$ \\
\hline Antidepressant medication ${ }^{\mathrm{a}}$ & 70 & (76) & 87 & $(95)$ & 32 & (94) & 189 & (87) \\
\hline ECT & 1 & (1) & 2 & $(2)$ & 2 & (7) & 5 & (3) \\
\hline Anxiolytics or hypnotics ${ }^{\mathrm{b}}$ & 33 & $(41)$ & 40 & $(46)$ & 23 & $(72)$ & 96 & (48) \\
\hline Psychotherapy & 7 & (8) & 11 & (12) & 6 & (18) & 24 & (11) \\
\hline Psychosocial support & 83 & $(90)$ & 79 & (88) & 28 & $(82)$ & 190 & $(88)$ \\
\hline Visits to psychiatrist, mean $\pm \mathrm{sd}^{\mathrm{c}}$ & \multicolumn{2}{|c|}{$2.7 \pm 2.5$} & \multicolumn{2}{|c|}{$4.8 \pm 4.6$} & \multicolumn{2}{|c|}{$6.4 \pm 7.2$} & \multicolumn{2}{|c|}{$4.1 \pm 4.5$} \\
\hline Number of all visits, mean $\pm \mathrm{sd}^{\mathrm{d}}$ & \multicolumn{2}{|c|}{$16.5 \pm 14.9$} & \multicolumn{2}{|c|}{$25.8 \pm 25.3$} & \multicolumn{2}{|c|}{$20.6 \pm 16.7$} & \multicolumn{2}{|c|}{$21.3 \pm 20.9$} \\
\hline
\end{tabular}

Abbreviations: NS= non-suicidal, $\mathrm{SI}=$ suicidal ideation, $\mathrm{SA}=$ suicide attempt, $\mathrm{ECT}=$ electro convulsive therapy.

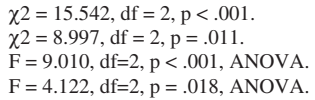

Table 9. Patients' attitudes and self-reported adherence to treatment after six-month follow-up classified by suicidal behaviour at baseline.

\begin{tabular}{|c|c|c|c|c|c|c|c|c|}
\hline & $\begin{array}{l}\text { NS } \\
\mathbf{N}\end{array}$ & $(\%)$ & $\begin{array}{l}\mathbf{S I} \\
\mathbf{N}\end{array}$ & $(\%)$ & $\begin{array}{l}\text { SA } \\
\mathbf{N}\end{array}$ & $(\%)$ & $\begin{array}{l}\text { Total } \\
\mathbf{N}\end{array}$ & $(\%)$ \\
\hline Overall & 92 & $(42)$ & 92 & $(42)$ & 34 & (16) & 218 & $(100)$ \\
\hline \multicolumn{9}{|l|}{ Positive attitudes towards } \\
\hline $\begin{array}{l}\text { Psychotherapeutic } \\
\text { treatment at baseline }\end{array}$ & 80 & (89) & 74 & (82) & 27 & $(82)$ & 181 & (85) \\
\hline $\begin{array}{l}\text { Psychotherapeutic } \\
\text { treatment at six months }\end{array}$ & 90 & (98) & 92 & $(100)$ & 33 & (97) & 215 & (99) \\
\hline $\mathrm{AD}$ treatment at $\mathrm{bl}^{\mathrm{a}}$ & 39 & (43) & 70 & (76) & 26 & (77) & 135 & $(62)$ \\
\hline $\mathrm{AD}$ treatment at six months ${ }^{\mathrm{b}}$ & 61 & (68) & 74 & (80) & 27 & $(82)$ & 162 & (75) \\
\hline Anxiolytics/Hypnotics ${ }^{\mathrm{c}}$ & 32 & $(38)$ & 33 & (38) & 20 & $(65)$ & 85 & $(42)$ \\
\hline $\begin{array}{l}\text { Good adherence to psychotherapeutic } \\
\text { treatment }\end{array}$ & 60 & (74) & 59 & (67) & 20 & $(69)$ & 139 & (70) \\
\hline Good adherence to AD treatment & 56 & (69) & 63 & (71) & 21 & (70) & 140 & (70) \\
\hline
\end{tabular}

Abbreviations: NS= non-suicidal, $\mathrm{SI}=$ suicidal ideation, $\mathrm{SA}=$ suicide attempt, $\mathrm{AD}=$ Antidepressive medication.

$\chi 2=24.975, \mathrm{df}=2, \mathrm{p}<.001$.

$\chi^{2}=9.951, \mathrm{df}=4, \mathrm{p}=.04$.

$\chi 2=8.751, \mathrm{df}=4, \mathrm{p}<.068$ 


\section{DISCUSSION}

\subsection{Main findings}

Among psychiatric in- and outpatients with DSM-IV major depressive disorder, patients with suicidal ideation or suicide attempts clearly had a higher level of overall psychopathology. $58 \%$ of the patients reported suicidal ideation during the current episode and $15 \%$ had attempted suicide at the baseline. Suicidal ideation was prevalent in almost all $(95 \%)$ of the $15 \%$ of patients who had attempted suicide. The risk factors for suicidal ideation and attempts appeared largely to overlap.

During the 18-month prospective follow up, $8 \%$ of the patients with MDD attempted suicide. The risk of an attempt was almost eight-fold during a major depressive episode compared with a period of full remission. Suicide attempt during the follow-up period was effectively predicted by three independent factors: lack of a partner, history of previous suicide attempts and time spent in major depressive episodes. Effective treatment of depression is a credible preventive measure for suicide attempts.

Suicidal ideation resolved in the majority of the suicidal MDD patients during the first 2 to 3 months. The duration of suicidal ideation was longer for patients with a higher level of psychopathology, such as initially high level of suicidal ideation or depressive symptoms at the baseline, or some personality disorder. Independent declines both in depression and hopelessness predicted the ensuing decline in suicidal ideation, and they both could have a causal role in the reversal of the suicidal process.

Patients with suicidal behaviour often received more antidepressants, had more frequent appointments with attending psychiatrists and received greater psychotherapeutic support from other mental health professionals than non-suicidal patients. Suicidal patients also had more favourable attitudes towards antidepressant treatment, and comparable adherence to treatment than those not suicidal.

Problems in the adequacy of treatment or attitudes or adherence to treatment, were not the factors markedly differentiating suicidal patients. Instead these problems appear to be generic to all psychiatric care. 


\subsection{Methods}

\subsubsection{Representativeness of the sample}

The present study involved a relatively large $(\mathrm{N}=269)$ cohort of both out- and inpatients with MDD, effectively representing all psychiatric patients with a new episode of MDD in the city of Vantaa, Finland.

Two thirds of all depressed subjects in the general population of the city of Vantaa seeking treatment from psychiatrists are treated at the PMCD (Rytsälä et al., 2001). This study took place during the era of current antidepressants in 1997-1999 in a modern community psychiatric setting; at the baseline, $78 \%$ of the patients received antidepressants at adequate levels during the acute phase in compliance with the APA Practice Guideline (Melartin et al., 2004).

\subsubsection{Diagnostic measures}

Patients entering the study were carefully diagnosed using semi-structured interviews with excellent reliability $(\kappa=0.86)$ for the diagnosis of MDD. However, the reliability of comorbid disorder diagnoses remains unknown. Axis II diagnoses were assessed using the semi-structured SCID-II interview for DSM-II-R (because in 1997 SCID-II for DSM-IV was not available). Differences between DSM-III-R and DSM-IV were taken into account.

\subsubsection{Life-chart methodology}

Keller et al. (1987) introduced in the NIMH-CDS the Longitudinal Interval Follow-up Evaluation (LIFE) methodology, first used to investigate the outcome of depression. In the VDS the course of depression was assessed during the follow-up by using a graphic life-chart methodology, which is a similar but not identical to LIFE. All patient records and monthly BDI-ratings (for the first 6 months) were available. Patients' follow-up time was classified into periods of DSM-IV MDE, partial remission, or full remission.

\subsubsection{Drop outs}

The rate of total drop-outs was low, as $87 \%$ of the cases could be interviewed at least once after the baseline. The patients whose diagnosis switched to bipolar I or II during the follow-up period (5\%) were excluded from the analyses.

However, due to deaths, diagnostic switch to bipolar disorder and dropping out after 6 months, $74 \%$ of the original 269 patients were included in the prospective follow-up study (Study II). 
The characteristics of patients in the Vantaa Depression Study do not differ in terms of comorbidity and symptom severity from the few other studies that have reported them comprehensively (Zimmerman et al., 2000; Tedlow et al., 2002), supporting the generalizeability of the findings to other settings. Factors associating with dropping out included both postive (younger age) and negative (living alone) outcome predictors.

In Study III, 70 suicidal patients (68\%) out of 103 could be followed up on weekly basis. These patients had a higher level of psychopathology than the VDS cohort overall, or the suicidal cases who did not participate in the weekly follow-up. It is unlikely that the findings would have been different with patients who dropped out included. Suicidal depressive patients commonly differ more from the non-suicidal in their subjective than objective measures on depression. (Malone et al., 1995, van Praag \& Plutchik, 1984; Cornelius et al., 1995, Oquendo et al., 1999). In this sample there appeared to be a similar trend.

In Study IV, it could not be determined how many of the patients who refused to participate in the study had suicidal ideation, or attempted suicide, how they were treated, and whether these patients differed from consenting patients with regard to their attitudes and adherence to treatment.

\subsubsection{Measurement of suicidal behaviour}

The present study is among the few (Rifai et al., 1994; Malone et al., 1995; Corbitt et al. 1996; Malone et al., 2000, Oquendo et al., 2002; 2004) to have employed a psychometric scale (SSI) to measure current suicidal ideation. It is also one of the few to involve a relatively large and unselected sample of both in- and outpatients with major depressive disorder. It is quite common to use an individual item from BDI (item 9) or HAM-D (item 3) or from some other questionnaire to investigate the prevalence or the level of suicidal ideation. Having a psychometric scale included in the study design is far more reliable than just a single item, which is much more vulnerable to random fluctuation. However, suicidal ideation during the entire current MDE was explored also by direct questioning.

A predetermined cut-off point ( $S S I \geq 6)$ was used to define moderate to severe current suicidal ideation. In retrospect, this may have been somewhat high (Beck et al., 1999; Holi et al., 2005), although applying an alternative lower cut-off point (SSI $\geq 2)$ did not change our findings. In addition, although the internal consistency of SSI was high (Cronbach's alpha 0.85-0.90), its inter-rater reliability remains unknown. 


\subsection{Results}

\subsubsection{Suicidal ideation and attempts among patients with MDD (Study I)}

Suicidal ideation is common among psychiatric in- and outpatients with DSM-IV major depressive disorder; nearly two thirds $(58 \%)$ of the patients reported suicidal ideation at the baseline, and suicidal ideation was prevalent in almost all (95\%) of the patients (15\%) who had attempted suicide.

There were significant differences between different groups. However, the risk factors found in the nominal regression models for suicidal ideation and attempts appeared largely to overlap, although the overall level of psychopathology and disability among the suicide attempters remained higher.

The role of substance use (alcohol) was probably crucial in suicide attempts. Although cluster B personality disorders and anxiety symptoms were more prevalent among suicidal patients compared to the whole group, neither appeared to be of major importance as an independent risk factor.

However, the cross sectional nature of the study limited our ability to make causal inferences, and prior to interview the temporal relationship between suicidal ideation and suicide attempt may be complicated.

The two forms of suicidal behaviour (ideation and attempts) were associated with several clinical variables, including severity of depression, alcohol dependence or abuse and anxiety, which is in concordance with earlier reports. In the regression models the risk factor domains overlapped, but were not identical. It also appeared that the impact of alcoholism and level of depression may be greater for suicide attempts.

\subsubsection{Risk factors for suicide attempt in MDD (Study II)}

During the 18-month prospective follow up, $8 \%$ of the patients with MDD attempted suicide and the risk of an attempt was almost eight-fold during a major depressive episode as compared with a period of full remission. The risk of suicide attempt effectively was predicted by three independent factors: lack of a partner, history of previous suicide attempts, and time spent in major depressive episodes.

To our knowledge, this study was the first prospective investigation to employ a life chart to place the suicide attempts, which allowed us to identify important disparities in risk between the periods of different levels of depressive symptoms. The findings of this study could be interpreted as evidence for the causal role of depression per se in the aetiology of suicide attempts. However, the high level of comorbidity with anxiety, 
substance use and personality disorders in the patient population (Melartin et al., 2002), are all factors independently related to suicidal behaviour, and thus the findings are far from self-evident.

Despite a large cohort of patients the most important limitation of the present study was that during the follow-up period, the number of suicide attempts was moderate and attempters rather small.

\subsubsection{Decline in suicidal ideation (Study III)}

Suicidal ideation was resolved in the majority of the suicidal MDD patients during the first two to three months. According to the original hypothesis, a decline in hopelessness would be the main determinant for the decline of suicidal ideation. However, in the joint analyses, declines both in depression and hopelessness independently predicted the following decline in suicidal ideation. This finding is consistent with the interpretation that both could have a causal role in reversal of the suicidal process. The duration of suicidal ideation was longer for patients with a higher level of psychopathology, such as an initially high level of suicidal ideation or depressive symptoms at the baseline, or some personality disorder.

In this study, 70 suicidal patients $(68 \%)$ out of 103 were followed up on weekly basis. These patients had an overall higher level of psychopathology than the VDS cohort overall, or those suicidal cases who did not participate in the weekly follow up. The duration of decline in suicidal ideation was strongly associated with the initial level of symptoms; the higher the initial level, the longer the duration. Personality disorders overall also had a significant impact on the duration of suicidal ideation. Contrary to original expectations, this was more related to overall rather than specifically, to cluster B or borderline personality disorder.

The decline of suicidal ideation was strongly associated with the preceding decline of depressive symptoms, level of hopelessness and anxiety. Even some decrease in the level of depression seemed to be enough to initiate the decline in the intensity of suicidal ideation. Suicidal ideation resolved gradually after depressive symptoms and hopelessness have started to alleviate. The duration of ideation and the time the patients fulfilled the criteria for a major depressive episode seemed to be similar.

Both depressive symptoms and hopelessness have a strong and consistent association with suicidal ideation (Van Gastel et al. 1997, Pages et al. 1997, Malone et al. 2000), and they are plausible and theoretically coherent risk factors for suicidal behaviour. The findings of this study are consistent with earlier findings (Szanto et al. 2003, Bruce et al. 2004) on the impact of treatment interventions to suicidal ideation among elderly depressives. 
The findings of this study are also consistent with the interpretation that declines in both depression and hopelessness could have a causal role in reversing the suicidal process.

\subsubsection{Adequacy, attitudes and adherence to treatments (Study IV)}

In the fourth study patients with suicidal behaviour had at the baseline a higher level of overall psychopathology, a difference that persisted during the following 6 months. In contrast to original expectations, they received antidepressants more often, had more frequent appointments with attending psychiatrists and received greater psychotherapeutic support from other mental health professionals than non-suicidal patients. Suicidal patients also had more favourable attitudes towards antidepressant treatment, and comparable adherence to treatment than those not suicidal. However, if the severity of depression (HAM-D score) was adjusted in the analyses, the significance was lost. Thus, neither problems in adequacy of treatment nor attitudes or adherence to treatment were factors markedly differentiating suicidal patients. Instead these problems appear to be generic to all psychiatric care.

According to the results of this study, treatment appeared to be allocated rationally. Probably due to higher severity of depression, patients with suicidal ideation or suicide attempts more often received antidepressants, adequate antidepressant treatment and frequent appointments with psychiatrists plus psychotherapeutic support from other professionals than non-suicidal patients. Thus, suicidal behaviour among psychiatric patients with MDD is not a factor that markedly influence the treatments provided.

Continuity presented a challenge in treatment here, as in psychiatric care in general. Although most MDD patients received antidepressant treatment in the early acute phase, about half terminated treatment prematurely (Melartin et al.,2005). Good adherence to treatments by patients reduced the probability of relapse or recurrence of MDD (Melfi et al., 1998). Thus, treating MDD is a central component of suicide prevention. According to the original hypothesis, patients with suicidal behaviour would have stronger negative attitudes and adherence to treatments than patients not exhibiting suicidal behaviour. The issues of compliance, high attrition rate and poor adherence are well known problems from earlier studies (Isacsson et al, 1994; Suominen et al., 1996). Unexpectedly though, in this cohort suicidal patients had more favourable attitudes towards antidepressant treatment than non-suicidal patients, and comparable adherence to treatment. Therefore it seems that the patients who remain in treatment have a positive attitude, and good adherence to treatments received. 


\section{CONCLUSIONS AND FUTURE IMPLICATIONS}

\subsection{Conclusions and clinical implications}

Suicidal ideation among psychiatric patients with MDD is markedly prevalent and it appears to be a precondition for suicide attempts. While ideation is also highly prevalent among depressed patients attempting suicide, the risk factors for suicidal ideation and attempts cover several clinical and psychosocial areas and largely seem to overlap. Substance use disorders and severity of depression may be of particular importance in predicting suicide attempts.

Suicide attempts among patients with MDD are strongly associated with the presence and severity of depressive symptoms. The risk of an attempt during a major depressive episode is clearly higher compared with a period of full remission. Lacking a partner, having a history of suicidal behaviour and time spent being depressed seem to be the strongest risk factors for future suicide attempt. Reducing time spent depressed is a highly credible preventive measure for future suicide attempts.

The decline of suicidal ideation appears to be associated with preceding declines in depressive symptoms and hopelessness and thus, they may have a causal relationship. However, for patients with higher level of psychopathology, it takes longer for suicidal ideation to alleviate.

Suicidal patients with MDD are known to have multidimensional problems, but this study does not support the conception that patients with suicidal behaviour had more negative attitudes or non-adherence to treatments than non-suicidal patients. These problems seem to be common to all psychiatric care patients with MDD.

It is likely that better recognition of suicidal behaviour (both ideation and attempts) and its risk factors among depressive patients will improve the outcome.

Psychiatric in- and outpatients with MDD have a high level of comorbidity with anxiety, substance use and personality disorder, all of which independently implicate elevated risk for suicide attempts. Nevertheless, risk for suicide attempt is almost eightfold during a major depressive episode compared with an episode of full remission. As suicide attempts are temporally associated with the presence of depressive symptoms, reducing the duration of the depressed state would be an effective measure for the prevention of suicidal acts.

The duration of suicidal ideation approximately corresponds the time the patients fulfil the criteria for a major depressive episode. Thus, even some decrease in the level of 
depression seems to be enough to initiate the decline in the intensity of suicidal ideation. Effective treatment of MDD will have a positive impact on the decline of hopelessness and thus probably in reversing suicidal ideation.

Suicidal patients with MDD are at higher risk of completed suicide and thus, they should receive more intensive treatment. For the purpose of preventing suicide it is important that neither suicidal ideation nor suicide attempt seem to be associated with more negative attitudes or non-adherence to treatments.

\subsection{Implications for future research}

Although research on suicidal behaviour has long traditions, it focuses mainly on suicide attempts and completed suicides. Prospective studies focusing on suicidal ideation in MDD, and the use of a psychometric scale for measuring suicidal ideation, are still quite rare. More prospective long-term studies are needed. Such studies would help us understand better the course and nature of suicidal behaviour and possible comorbid factors in MDD.

We need studies focusing on the short-term course of suicidal ideation in special subgroups, such as cluster B personality disorders.

Earlier long-term studies have focused, among others, on the association between suicidal ideation and hopelessness with suicide attempts or completed suicides. While major depressive disorder is a heterogenous and comorbid disorder, those patients known to be suicidal, are at higher risk of completed suicide and should thus receive more intensive treatment. More research is needed to investigate the effectiveness of treatments for depression in reversing the suicidal process among adult patients with MDD.

Finally, problems concerning continuity, attitudes and adherence to treatments among patients with suicidal behaviour and MDD need more elucidation. 


\section{ACKNOWLEDGEMENTS}

This study was carried out at the department of Mental Health and Alcohol Research of the National Public Health Institute, Helsinki, and at the Department of Psychiatry of Helsinki University Central Hospital (HUCH), Peijas Hospital, Vantaa. I wish to thank both the former and the present Director General of the National Public Health Institute, Professor Jussi Huttunen, M.D., Ph.D., and Professor Pekka Puska, M.D., Ph.D. for the facilities provided to me by the Institute.

I want to express my gratitude to the head of the Psychiatric Department of HUCH, Peijas Hospital, Juhani Solantaus, M.D. for the opportunity of joining to this research work. As an academic dissertation, this work took place in the Department of Psychiatry at the University of Helsinki, for which I am most grateful.

I wish to express my gratitude to Professor Jouko Lönnqvist, M.D., Ph.D. for the privilege of of working at the Department of Mental Health and Alcohol Research.

I owe my profound gratitude to my supervisor, Professor Erkki Isometsä, M.D., Ph.D., Department of Psychiatry, University of Helsinki and Research Professor, Head of Mood Disorders Research at the Department of Mental Health and Alcohol Research of the National Public Health Insitute, for his guidance in the scientific wilderness, encouragement, devotion and patience.

I would like thank the reviewers of this thesis, acting Professor Sari Lindeman, M.D., Ph.D. and docent Tero Taiminen, M.D., Ph.D, for their valuable advice and constructive criticism, which significantly improved the text.

I want to warmly thank my fellow-researchers and co-authors, Ulla Leskelä, M.A., Paula Lestelä-Mielonen, M.A, Tarja Melartin, M.D., Ph.D and Heikki Rytsälä, M.D. for their collaboration and scientific contribution to the various manuscripts. Special thanks to Tarja Melartin for opening the path for the rest of us. My warmest thanks to Eevaliisa Orelma and Marjut Screck for their untiring efforts to make it all happen.

Sincere thanks to Professor Mauri Marttunen, M.D., Ph.D. for his contribution to the educational and developmental part of the study project and also his personal support and guidance throughout the years.

I have had the pleasure to work with numerous colleagues over the years and I want to thank them all, as well as all the personnel of the different clinics. 
I want to express my sincere gratitude to Sirkka Laakso, Tiina Hara, Tuula Koski, and Olli Kiviruusu for their help in various practical matters. I am grateful to statisticians, Mervi Eerola, Ph.D. (also co-author of the Study III) and Erkki Komulainen, Ph.D. for their special skills, patience and guidance. I would also like to thank Richard Burton, B.Sc. for revising the text of the original manuscripts (I-II) and Liisa Roponen for revising the text of this thesis. I want to also thank the library personnel at the National Public Health Institute and at the University of Helsinki.

I am most grateful to my parents and family, other relatives and friends for their support in numerous ways during these years. Thank also to Reijo Kalmakurki for his contribution in the past.

I owe my deepest and profound gratitude to my wife Tuija, for her love and support. Without you all this would have been impossible. Special thanks to our children, Mikael, Saara, Lempi and Eero.

This study has been financially supported by the Academy of Finland, the Finnish Medical Foundation, the Yrjö Jahnsson Foundation, and Research Funds of Helsinki University Central Hospital and HUCH, Peijas Hospital.

Finally, I express my warmest appreciation to all the patients who participated in this study. 


\section{REFERENCES}

Abbar M, Courtet P, Bellivier F, Leboyer M, Boulenger JP, Castelhau D, Ferreira M, Lambercy C, Mouthon D, Paoloni-Giacobino A, Vessaz M, Malafosse A, Buresi C. Suicide attempts and the tryptophan hydroxylase gene. Mol Psychiatry 2001;6:268-73.

Alexopoulos GS, Bruce Ml, Hull J, Sirey JA, Kakuma T: Clinical determinants of suicidal ideation and behavior in geriatric depression. Arch Gen Psychiatry 1999:56;1048-1053.

Allgulander C: Suicide and mortality patterns in anxiety neurosis and depressive neurosis. Arch Gen Psychiatry 1994; 51: 708-712.

Alonso J, Angermayer MC, Bernert S, Bruffaerts R, Brugha TS, Bryson H, de Girolamo G, de Graaf R, Demyttenaere K, Gasquet I, Haro JM, Katz SJ, Kessler RC, Kovess V, Lepine J, Ormel J, Polidori G, Russo LJ, Vilagut G, Almansa J, Arbabzadeh-Bouchez S, Autonell J, Bernal M, Buist-Bouwman MA, Codony M, Domingo-Salvany A, Ferrer M, Joo SS, MartinezAlonso M, Matschinger H, Mazzi F, Morgan Z, Morosini P, Palacin C, Romera B, Taub N, Vollerbergh WAM. Prevalence of mental disorders in Europe: results from the European Study of the Epidemiology of Mental Dirorders (ESEMeD) project. Acta psychiatr Scand 2004:109 (Suppl 420):21.27.

American Psychiatric Association (APA). Diagnostic and Statistical Manual of Mental Disorders, $3^{\text {rd }}$ Edition revised (DSM-III-R). Washington, DC; American Psychiatric Association, 1987.

American Psychiatric Association (APA). Diagnostic and Statistical Manual of Mental Disorders, $4^{\text {th }}$ Edition (DSM-IV). Washington, DC; American Psychiatric Association, 1994.

American Psychiatric Association (APA). Diagnostic and Statistical Manual of Mental Disorders, $4^{\text {th }}$ Edition, Text revision. Washington, DC; American Psychiatric Association, 2000.

American Psychiatric Association (APA). Practice guideline for the treatment of patients with major depressive disorder [Revision]. Am J Psychiatry 2000; 157 (suppl 4): 1-45.

American Psychiatric Association (APA). Practice guideline for the assessment and treatment of patients with suicidal behaviors. Am J Psychiatry 2003; 160 (suppl 11): 1-60.

Angst J. The course of affective disorders. Psychopathology 1986;19:47-52. 
Angst J, Angst F, Gerber-Werder R, Gamma A. Suicide in 406 mood-disorder patients with and without long-term medication: a 40 to 44 years' follow-up. Arch Suicide Res 2005;9:279-300.

Angst J, Clayton P. Premorbid personality of depressive, bipolar, and schizophrenic patients with special reference to suicidal issues. Compr Psychiatry 1986;27:511-532.

Anderson IM, Nutt DJ, Deakin JFW, on behalf of the Consensus Meeting and endorsed by the British Association for Psychopharmacology. J Psychopharmacol 2000;14:3-20.

Appleby L, Dennehy JA, Thomas CS, Faragher EB, Lewis G. Aftercare and clinical characteristics of people with mental illness who commit suicide: a case-control study. Lancet 1999;353:1397-400.

Appleby L, Swinson N, Kapur N. Making mental health services safer. In Prevention and treatment of suicidal behaviour. From science to practice. Ed. Hawton K. Oxford University Press. 2005.

Arango V, Underwood MD, Gubbi AV, Mann JJ. Localized alterations in pre- and postsynaptic serotonin binding sites in the ventrolateral prefrontal cortex of suicide victims. Brain Res 1995;688:121-133.

Arsenault-Lapierre G, Kim C, Turecki G. Psychiatric diagnoses in 3275 suicides: a meta-analysis. BMC Psychiatry 2004;4:37.

Asnis GM, Friedman TA, Sanderson WC, Kaplan ML, van Praag H, Harkavy-Freidman JM: Suicidal behaviors in adult psychiatric outpatients, I: Description and prevalence.Am J Psychiatry 1993;150:108-112.

Avery D, Winokur G: Suicide, attempted suicide, and relapse rates in depression. Arch Gen Psychiatry 1978; 35: 749-753.

Barraclough B, Bunch J, Nelson B, Sainsbury P. A hundred cases of suicide: Clinical aspects. Br J Psychiatry 1974;125:355-373.

Bartels SJ, Drake RE, McHugo GJ. Alcohol abuse, depression, and suicidal behavior in schizophrenia. Am J Psychiatry 1992;149(3):394-395.

Bauer M, Whybrow PC, Angst J, Versiani M, Moller HJ; World Federation of Societies Biological Psychiatry Task Force on Treatment Guidelines for unipolar Depressive Disorders. World Federation of Societies of Biological Psychiatry (WFSBP) Guidelines for Biological Treatment of Unipolar Depressive Disorders, Part 1: Acute and continuation treatment of major depressive disorder. World J Biol Psychiatry 2002;3(1):5-43. 
Beautrais AL. Risk factors for suicide and attempted suicide amongst young people. National Health and Medical Research Council, Canberra.1999.

Beautrais AL. Suicides and serious suicide attempts: two populations or one? Psychol Med 2001;31:837-845.

Beautrais AL. Gender issues in youth suicidal behaviour. Emerg Med 2002;14:35-42.

Beautrais AL, Joyce PR, Mulder RT, Fergusson DM, Deavoll BJ, Nightingale SK. Prevalence and comorbidity of mental disorders in persons making serious suicide attempts: a casecontrol study. Am J Psychiatry 1996;153(8):1009-1014.

Beck AT: Hopelessness as a predictor of eventual suicide. Ann N Y Acad Sci 1986;487:90-96.

Beck AT. Cognitive approaches to suicide. In Suicide prevention and intervention. Goldsmith S (Ed.) Washington, DC. National Academy Press, 2001.

Beck AT. The current state of cognitive therapy. A 40-year retrospective. Arch Gen Psychiatry 2005;62:953-959.

Beck AT, Brown G, Berchick RJ, Stewart BL, Steer RA. Relationship between hopelessness and ultimate suicide: a replication with psychiatric outpatients. American Journal of Psychiatry 1990;147:190-195.

Beck AT, Brown G, Epstein N, Steer RA. An inventory for measuring clinical anxiety: Psychometric properties. J Consult Clin Psychol 1988,56: 893-897.

Beck AT, Brown GK, Steer RA, Dahlsgaard KK, Grisham JR. Suicide ideation at its worst point: a Predictor of eventual suicide in psychiatric outpatients. Suicide Life Threat Behav 1999:29(1);1-9.

Beck AT, Greenberg R. The nosology of suicidal phenomena: Past and future perspectives. Bulletin of Suicidology 1971;8:10-17.

Beck AT, Kovacs M, Weissman A. Hopelessness and suicidal behavior. JAMA 1975;234:1146-1149.

Beck AT, Kovacs M, Weissman A. Assessment of suicidal intention. The Scale for Suicidal Ideation. J Consult Clin Psychol 1979;47(2):343-352.

Beck AT, Resnik HLP, Lettieri D (eds.). Measurement of suicidal behaviors. New York. Charles Press 1973. 
Beck AT, Ward CH, Mendelson M, Moch JE, Erbauch JK. An inventory for measuring depression. Arch Gen Psychiatry 1961;4:561-565.

Beck AT, Weishaar ME. Suicide risk assessment and prediction. Crises 1990;22:22-30.

Beck AT, Weissman A, Lester D, Trexler L. The measure of pessimism: The hopelessness scale. J Consult Clin Psychol 1974;42: 861-865.

Belliver F, Chaste P, Malafosse A. Association between the TPH gene A218C polymorphism and suicidal behavior: a meta-analysis. Am J Med Genet B Neuropsychiatr Genet 2004;124:87-91.

Biegon A. Fieldus S. Reduced tyrosine hydroxylase immunoreactivity in locus coeruleus of suicide victims. Synapse 1992;10:79-82.

Bijl RV, Ravelli A, van Zessen G. Prevalence of psychiatric disorder in the general population: results of the Netherlands Mental Health Survey and Incidence Study (NEMESIS). Soc Psychiatry Psychiatr Epidemiol 1998;33:587-595.

Blair-West GW, Cantor CH, Mellsop GW, Eyeson-Annan ML. Lifetime suicide risk in major depression: sex and age determinants. JAD 1999;55:171-178.

Blumenthal JA, Burg MM, Braefoot J, Williams RB, Haney T, Zimet G. Social support, type A behavior, and coronary artery disease. Psychosom Med 1987; 49: 331-340.

Bondy B, Buettner A, Zill P. Genetics of suicide. Mol Psychiatry 2006;11:336-351.

Bonner RL, Rich AR: Toward a model of suicidal ideation and behavior: some preliminary data in college students. Suicide Life Threat Behav 1987 Spring; 17(1): 50-63.

Bostwick JM, Pankratz VS. Affective disorders and suicide risk: a reexamination. Am J Psychiatry 2000;157:1925-1932.

Boyce P, Parker G, Barnett B, Cooney M, Smith F. Personality as a vulnerability factor to depression. Br J Psychiatry 1991;159:106-114.

Brent DA, Mann JJ. Family genetic studies, suicide, and suicidal behavior. Am J Med Genet C Semin Med Menet 2005;133(1):13.24.

Breslau N. Migraine, suicidal ideation, and suicide attempts. Neurology 1992;42:392-395.

Breslau N, Schultz L, Peterson E. Sex diffrences in depression: a role of preexisting anxiety. Psychiatry Res 1995;58:1-12. 
Brodaty H, Luscombe G, Peisah C, Anstey K, Andrews G. A 25-year longitudinal, comparison study of the outcome of depression. Psychol Med 2001;31(8):1347-59.

Bronisch T, Hecht H: Prospective long-term follow-up of depressed patients with and without suicide attempts. Eur Arch Psychiatry Clin Neurosci 1992; 242: 13-19.

Bronisch T, Wittchen H.-U.: Suicidal ideation and suicide attempts: comorbiditywith depression, anxiety disorders, and substance abuse disorder. Eur Arch Psychiatry Clin Neurosci 1994; 244: 93-98.

Brown GK, Beck AT, Steer RA, Grisham JR. Risk factors for suicide in psychiatric outpatients: a 20-year prospective study. J Consult Clin Psychol 2000;68(3):371-7.

Brown GW, Harris TO. Social origins of depression: a study of psychiatric disorder in women. London, Tavistock, 1978.

Bruce ML, Ten Have TR, Reynolds CF 3rd, Katz II, Schulberg HC, Mulsant BH, Brown GK, McAvay GJ, Pearson JL, Alexopoulos GS. Reducing suicidal ideation and depressive symptoms in depressed older primary care patients: a randomized controlled trial. JAMA 2004;291:1081-91.

Brådvik L. Suicide after suicide attempt in severe depression. A long-term follow-up. Suicide Life Threat Behav 2003;33:381-388.

Bulik CM, Carpenter LL, Kupfer DJ, Frank E: Features associated with suicide attempts in recurrent major depression. J Affect Disord 1990; 18: 29-37.

Burge V, Felts M, Chenier T, Parrillo AV. Drug use, sexual activity, and suicidal behavior in U.S. high school students. J Sch Health 1995;65(6):222-227.

Casey P, Birbeck G, McDonagh C, Horgan A, Dowrick C, Dalgard O, Lehtinen V, AyusoMateos JL, Dunn G, Page H, Wilkinson C, Wilkinson G, Vazquez-Barquero JL; the ODIN group. Personality disorder, depression and functioning: results from the ODIN study. JAD 2004; 82(2):277-283.

Caspi A, Moffitt TE, Newman DL, Silva PA. Behavioral observations at age 3 years predict adult psychiatric disorders: longitudinal evidence from a birth cohort. Arch Gen Psychiatry 1996;53:1033-1039.

Caspi A, Sudgen K, Moffitt TE, Taylor A, Craig IW, Harrington H, McClay J, Mill J, Martin J, Braithwaite A, Poulton R. Influence of life stress on depression: moderation by a polymorphism in the 5-HTT gene. Science 2003;301:386-389. 
Castrogiovanni P, Pieraccini F, Di Muro A: Suicidality and aggressive behaviour. Acta Pasychiatr Scand 1998; 97: 144-148.

Cavanagh JTO, Carson AJ, Sharpe M, lawrie M. Psychological autopsy studies of suicide: a systematic review. Psychol Med 2003;33:395-405.

Cheng AT. Mental illness and suicide. A case-control study in east Taiwan. Arch Gen Psychiatry 1995;52:594-603.

Cipriani A, Pretty H, Hawton K, Geddes JR. Lithium in the prevention of suicidal behavior and all-cause mortality in patients with mood disorders: a systematic review of randomized trials. Am J Psychiatry 2005;162(10):1805-19.

Cooper Z, Paykel ES. Social factors in the onset and maintenance of depression. In Principles of social psychiatry. Bhugra D, Leff $\mathrm{J}$ (Eds.), Oxford: Blackwell scientific Publications, 1994.

Corbitt EM, Malone KM, Haas GL, Mann JJ: Suicidal behavior in patients with major depression and comorbid personality disorders. J Affect Disord 1996; 39: 61-72.

Cornelius JR, Salloum IM, Mezzich J, Cornelius MD, Fabrega H, Ehler JG, Ulrich RF, Thase MS, Mann JJ: Disproportionate suicidality in patients with comorbid major depression and alcoholism. Am J Psychiatry 1995:152;358-364.

Coryell W, Young EA. Clinical predictors of suicide in primary major depressive disorder. J Clin Psychiatry 2005;66:412-417.

Crismon ML, Trivedi M, Pigott TA, Rush AJ, Hirschfeld RM, Kahn DA, DeBattista C, Nelson JC, Nierenberg AA, Sackheim HA, Thase ME. The Texas Medication Algorithm Project: report of the Texas Consensus Conference Panel on Medication Treatment of Major Depressive Disorder. J Clin Psychiatry 1999;60(3):142-56.

Crook T, Raskin A, Davis D: Factors associated with attempted suicide among hospitalized depressed patients. Psychol Med 1975; 5: 381-388.

Crosby AE, Cheltenham MP, Sacks JJ. Incidence of suicidal ideation and behavior in the United States, 1994. Suicide Life Threat Behav 1999;29:131-40.

De Luca V, Voineskos D, Wong GW, Shinkai T, Rothe C, Strauss J, Kennedy JL. Promoter polymorphism of second tryptophan hydroxylase isoform (TPH2) in schizophrenia and suicidality. Psychiatry Res 2005;134:195-198. 
DeRubeis RJ, Hollon SD, Amsterdam JD, Shelton RC, Young PR, Salomon RM, O'Reardon P, Lovett ML, Gladis MM, Brown LL, Gallop R. Cognitive therapy vs medications in the treatment of moderate to severe depression. Arch Gen Psychiatry 2005;62:409-16.

Diekstra RFW: The epidemiology of suicide and parasuicide. Acta Psychiatr Scand 1993; Suppl 371: 9-20

Diekstra RFW, Garnefski N. On the nature, magnitude, and causality of suicidal behaviors: An international perspective. Suicide Life Threat Behav 1995;25(1):36-57.

Dixon WA, Heppner PP, Rudd MD. Problem-solving appraisal, hopelessness, and suicide ideation: evidence for a mediational model. J Counsel Psychol 1994;41:91-98.

Dorpat TL, Ripley HS. A study of suicide in Seattle area. Compr Psychiatry 1960;1:349359.

Duggan CF, Sham P, Lee AL, Murray RM: Can future suicidal behaviour in depressed patients be predicted? J Affect Disord 1991; 21: 111-118.

Durkheim E. Suicide - a study in sociology. Republished in 1952 by Routledge and Kegan Paul, London.

Dumais A, Lesage AD, Alda M, Rouleau G, Dumont M, Chawky N, Roy M, Mann JJ, Benkelfat C, Turecki G. Risk factors for suicide completion in major depression: a case-control study of impulsive and aggressieve behaviors in men. Am J Psychiatry 2005;162:2116-2124.

Eaton WW, Anthony JC, Gallo J, Cai G, Tien A, Romanoski A, Lyketsos C, Chen L-S. Natural history of Diagnostic Interview Schedule / DSM-IV major depression. The Baltimore Epidemiologic Catchment Area follow-up. Arch Gen Psychiatry 1997;54:993-999.

Eitan R, Lerer B. Nonpharmacological, somatic treatments of depression: electroconvulsive therapy and novel brain stimulation modalities. Dialogues Clin Neurosci 2006;8:241-58.

Ernst C, Olson AK, Pinel JP, Lam RW, Christie BR. Antidepressant effects of exercise: evidence for an adult-neurogenesis hypothesis? J Psychiatry Neurosci 2006;31:84-92.

Fawcett J, Scheftner W, Clark D, Hedeker D, Gibbons R, Coryell W. Clinical predictors of suicide in patients with major affective disorders: a controlled prospective study. Am J Psychiatry 1987;144:35-40.

Fawcett J, Scheftner WA, Fogg L, Clark DC, Young MA, Hedeker D, Gibbons R. Time-related predictors of suicide in major affective disorder. Am J Psychiatry 1990;147:1189-1194. 
Ferguson DM, Mullen PE. Childhood sexual abuse: An evidence based perspective. Thousand Oaks, Calif, Sage Publications, 1999.

Freud S. Mourning and melancholia. Standard Edition, Vol 14. Erlbaum. London. 1917.

Friedman RC, Aronoff MS, Clarkin JF, Corn R, Hurt SW: History of suicidal behavior in depressed borderline inpatients. Am J Psychiatry 1983; 140(8): 1023-1026.

Friedman JMH, Asnis GM, Boeck M, DiFiore J. Prevalence of specific suicidal behaviors in a high school sample. Am J Psychiatry 1987;144:1203-1206.

Friedman S, Jones JC, Chernen L, Barlow DH: Suicidal ideation and suicide attempts among patients with panic disorder: a survey of two outpatient clinics. Am J Psychiatry 1992; 149: 680-685.

Fyer MR, Frances AJ, Sullivan T, Hurt SW, Clarkin J: Suicide attempts in patients with borderline personality disorder. Am J Psychiatry 1988; 145: 737-739.

Gaynes BN, West SL, Ford CA, Frame P, Klein J, Lohr KN; U.S. Preventive Services Task Force. Screening for suicide risk in adults: a summary of the evidence for the U.S. Preventive Services Task Force. Ann Intern Med 2004;140(10):822-35.

Gladstone GL, Parker GB, Mitchell PB, Malhi GS, Wilhelm K, Austin MP. Implications of childhood trauma for depressed women: an analysis of pathways from childhood sexual abuse to deliberate self-harm and revictimization. Am J Psychiatry 2004;161:1417-1425.

Goldman HH, Skodol AE, Lave TR. Revising axis V for DSM-IV: a review of measures of social functioning. Am J Psychiatry 1992;149:1148-1156.

Goldney RD, Dal Grande E, Fisher LJ, Wilson D. Population attributable risk of major depression for suicidal ideation in a random and representative community sample. JAD 2003;74:267-272.

Goldney RD, Wilson D, Dal Grande E, Fisher LJ, McFarlane AC. Suicidal ideation in a random community sample: attributable risk due to depression and psychosocial and traumatic events. Aust N Z J Psychiatry 2000;34(1):98-106.

Goldney RD, Winefield AH, Tiggeman M, Winefield HR, Smith S. Suicidal ideation in a young adult population. Acta Psychiatr Scand 1989;79(5):481-489.

Guze SB, Robbins E. Suicide and primary affective disorders. Br J Psychiatry 1970;117:437-438. 
Haby MM, Donnelly M, Corry J, Vos T. Cognitive behavioural therapy for depression, panic disorder and generalized anxiety disorder: a meta-regression of factors that may predict outcome. Aust N Z J Psychiatry 2006;40:9-19.

Hamilton M. A rating scale for depression. J Neurol Neurosurg Psychiat 1960; 23: 56-62.

Hansen PEB, Wang AG, Stage KB, Kragh-Sorensen P, The Danish University Antidepressant Group. Comorbid personality disorder predicts suicide after major depression: a 10-year follow-up. Acta Psychiatr Scand 2003;107:436-440.

Harrington R, Fudge H, Rutter M, Pickles A, Hill J. Adult outcomes of childhood and adolescent depression, I. psychiatric status. Arch Gen Psychiatry 1990;47;465-473.

Harris EC, Barraclough B. Suicide as an outcome for mental disorders. A meta-analysis. Br J Psychiatry 1997; 170: 205-228.

Harris EC, Barraclough B. Excess mortality of mental disorder. Br J Psychiatry 1998;173:11-53.

Hasin DS, Goodwin RD, Stinson FS, Grant BF. Epidemiology of major depressive disorder. Results from the National Epidemiologic Survey on Alcoholism and Related Conditions. Arch Gen Psychiatry 2005;62:1097-1106.

Hawton K. Assessment of suicide risk. Br J Psychiatry 1987;150:145-153.

Hawton K, van Heeringen K: The international handbook of suicide and attempted suicide. Wiley 2000.

Heim C, Newport J, Heit S, Graham Y, Wilcox M, Bonsall R, Miller A, Nemeroff C. Pituitaryadrenal and automatic responses to stress in women after sexual and psysical abuse in childhood. JAMA 2000;284:592-597.

Hendersson A. Social support and depression. In The meaning and measurement of social support. Veiel H, Baumann U (Eds.), New York, Hemisphere, 1992.

Henriksson MM, Aro HM, Marttunen MJ, Heikkinen ME, Isometsä ET, Kuoppasalmi KI, Lönnqvist JK. Mental disorders and comorbidity in suicide. Am J Psychiatry 1993;150(6):935-40.

Hintikka J, Viinamäki H, Koivumaa-Tanskanen H-T, Saarinen P, Tanskanen A, Lehtonen J. Risk Factors for suicidal ideation in psychiatric patients. Soc Psychiatry Psychiatr Epidemiol 1998;33:235-240. 
Hirschfeld RM, Klerman GL, Lavori P, Keller MB, Griffith P, Coryell W. Premorbid personality assessments of first onset of major depression. Arch Gen Psychiatry 1989;46:345-350.

Holi MM, Pelkonen M, Karlsson L, Kiviruusu O, Ruuttu T, Heilä H, Tuisku V, Marttunen M. Psychometric properties and clinical utility of the Scale for Suicidal Ideation (SSI) in adolescents. BMC Psychiatry 2005;5(1):8.

Holmes SJ, Robins LN. The role of parental disciplinary practices in the development of depression and alcoholism. Psychiatry 1988;51:24-36.

Hurd YL, Herman MM, Hyde TM, Bigelow LB, Weinberger DR, Kleinman JE. Prodynorphin mRNA expression is increased in the patch vs matrix compartment of the caudate nucleus in suicide subjects. Mol Psychiatry 1997;2:495-500.

Hämäläinen J, Isometsä E, Laukkala T, Kaprio J, Poikolainen K, Heikkinen M, Lindeman S, Aro H. Use of healt services for major depressive episode in Finland. JAD 2004;79:105-112.

Höyer EH, Mortensen PB, Olesen AV: Mortality and causes of death in a total national sample of patients with affective disorders admitted for the first time between 1973 and 1993.Br J Psychiatry 2000; 176: 76-82.

Höyer EH, Olesen AV, Mortensen PB. Suicide risk in patients hospitalised because of an affective disorder: a follow-up study, 1973-1993. J Affect Disord 2004;78:209-17.

Ingersoll GM, Grizzle K, Beiter M, Orr DP. Frequent somatic complaints and psychosocial risk in adolescents. J Early Adolesc 1993;13:67-78.

Isacsson G, Bergman U, Rich CL. Antidepressants, depression and suicide: an analysis of the San Diego study. J Affect Disord 1994;32:277-86.

Isometsä ET. Psychological autopsy studies - a review. Eur Psychiatry 2001;16:379-385.

Isometsä E, Aro S, Aro H. Depression in Finland: a computer assisted telephone interview study. Acta Psychiatr Scand 1997;96(2):122-8.

Isometsä ET, Henriksson MM, Aro HM, Heikkinen ME, Kuoppasalmi KI, Lönnqvist JK: Suicide in major depression. Am J Psychiatry 1994; 151: 530-536.

Jacobi F, Wittchen HU, Hölting C, Höfler M, Pfister H, Müller N, Lieb R. Prevalence, comorbidity and correlates of mental disorders in the general population: results from the German Health Interview and Examination Survey (GHS). Psychol Med 2004;34(4):597-611. 
Jenkins R, Lewis G, Bebbington P, Brugha T, Farrel M, Gill B, Meltzer H. The National Psychiatric Morbidity surveys of Great Britain-initial findings from the household survey. Psychol Med 1997;27(4):775-89.

Joiner TE, Steer RA, Brown G, Beck AT. Worst-point suicidal plans: a dimension of suicidality predictive of past suicide attempts and eventual death by suicide. Behav Res Ther. 2003 Dec;41(12):1469-80.

Kandel DB, Raveis VH, Davies M. Suicidal ideation in adolescence: depression, substance use, and other risk factors. J Youth Adolesc 1991;20:289-308.

Keller MB, Lavori PW, Friedman B, Nielsen E, Endicott J, McDonald-Scott P, Andreasen NC. The Longitudinal Interval Follow-up Evaluation: a comprehensive method for assessing outcome in prospective longitudinal studies. Arch Gen Psychiatry 1987;44:540-548.

Keller MB, Lavori PW, Mueller TI, Endicott J, Coryell W, Hirschfeld RM, Shea T. Time to recovery, chronicity, and levels of psychopathology in major depression. A 5-year prospective follow-up of 431 subjects. Arch Gen Psychiatry 1992;49(10):809-16.

Kendler KS, Gardner CO, Prescott CA: Toward a comprehensive developmental model for major depression in women. Am J Psychiatry 2002;159:1133-1145.

Kendler KS, Gardner CO, Prescott CA: Toward a comprehensive developmental model for major depression in men. Am J Psychiatry 2006b;163:115-124.

Kendler KS, Gatz M, Gardner CO, Pedersen NL. A Swedish national twin study of lifetime major depression. Am J Psychiatry 2006a;163:109-114.

Kendler KS, Kuhn J, Prescott CA. The interrelationship of neuroticism, sex, and stressful life events in the prediction of episodes of major depression. Am J Psychiatry 2004;161:631-636.

Kennedy MA, Miller AL, Rogers G, Luty S, Mulder R, Joyce P. Polymorphic variants and associations analysis of TPH2, brain tryptophan hydroxylase. Neuropsychiatr Genet 2003; 122B:69.

Kessler RC. The effects of stressful life events on depression. Ann Rev Psychology 1997;48:191-214.

Kessler RC, Berglund P, Demler O, Jin R, Koretz D, Merikangas KR, Rush AJ, Walters EE, Wang PS; National Comorbidity Survey Replication (NCS-R). The epidemiology of major depressive disorder: results from the National Comorbidity Survey Replication (NCS-R). JAMA 2003;289(23):3095-105. 
Kessler RC, Berglund P, Borges G, Nock M, Wang PS. Trends in suicide ideation, plans, gestures, and attempts in the United States, 1990-1992 to 2001-2003. JAMA 2005;293:24872495.

Kessler RC, Borges G, Walters EE. Prevalence of and risk factors for lifetime suicide attempts in the National Comorbidity Survey. Arch Gen Psychiatry 1999;56:617-626.

Kessler RC, McGonagle KA, Zhao S, Nelson CB, Hughes M, Eshleman S, Wittchen HU, Kendler KS. Lifetime and 12-month prevalence of DSM-III-R psychiatric disorders in the United States. Results from the National Comorbidity Survey. Arch Gen Psychiatry 1994;51(1):8-19.

Kessler RC, Nelson CB, McGonagle KA, Liu J, Swartz M, Blazer DG. Comorbidity of DSM-III-R major depressive disorder in the general population: results from the National Comorbidity Survey. Br J Psychiatry Suppl 1996;30:17-30.

Khan A, Brodhead AE, Kolts RL, Brown WA. Severity of depressive symptoms and response to antidepressants and placebo in antidepressant trials. J Psychiatr Res 2005;39:145-50.

Kinkel RJ, Bailey CW, Josef NC. Suicide ideation in normal adolescents. Department of Sociology/Anthropology/Social Work, University of Michigan, Flint, 1988.

Klerman GL. Approaches to the phenomena of comorbidity. In Comorbidity of Mood and Anxiety Disorders. Maser JD, Cloninger CR (Eds.). Washington, DC, American psychiatric Press, 1990.

Korszun A, Moskvina V, Brewster S, Craddock N, Ferrero F, Gill M, Jones IR, Jones LA, Maier W, Mors O, Owen MJ, Preisig M, Reich T, Rietschel M, Farmer A, McGuffin P. Famiality of symptom dimensions in depression. Arch Gen Psychiatry 2004; 61:468-474.

Lalovic A, Turecki G. Meta-analysis of the association between tryptophan hydroxylase and suicidal behavior. Am J Med Genet 2002;114:533-540.

Lau MA, Segal ZV, Williams JMG. Teasdale's differential activation hypothesis: Implications for mechanisms of depressive relapse and suicidal behavior. Behav Res Ther 2004;42:1001-1017.

Lehtinen V, Joukamaa M. Epidemiology of depression: prevalence, risk factors and treatment situation. Acta Psychiatr Scand Suppl 1994;337:7-10.

Lepine JP, Chignon JM, Teherani M: Suicide attempts in patients with panic disorder. Arch Gen Psychiatry 1993; 51: 144-149. 
Lesch KP. Gene-environment interaction and the genetics of depression. J psychiatry Neurosci 2004;29:174-184.

Lewinsohn PM, Hoberman HM, Rosenbaum M. A prospective study of risk factors for unipolar depression. J Abnorm Psychol 1988;97:251-264.

Lieb R, Isensee B, Höfler M, Pfister P, Wittchen HU. Parental major depression and the risk of depression and other mental disorders in offspring. A prospective-longitudinal community study. Arch Gen Psychiatry 2002;59:365-374.

Lindeman S, Hämäläinen J, Isometsä E, Kaprio J, Poikolainen K, Heikkinen M, Aro H. The 12month prevalence and risk factors for major depressive episode in Finland: representative sample of 5993 adults. Acta Psychiatrica Scand 2000;102;178-184.

Linehan MM. Suicidal people. One population or two? Ann N Y Acad Sci 1986;487:16-33.

Lingam R, Scott J. treatment non-adherence in affective disorders. Acta Psychiatr Scand 2002;105:164-172.

Linkowski P, de Maertelaer V, Mendlewicz J. Suicidal behaviour in major depressive illness. Acta Psychiatr Scand 1985;72(3):233-238.

Little KY, Clark TB, Ranc J, Duncan GE. B-adrenergic receptor binding in frontal cortex from suicide victims. Biol Psychiatry 1993;34:596-605.

Luoma JB, Martin CE, Pearson JL. Contact with mental health and primary care providers before suicide: a review of the evidence. Am J Psychiatry 2002;159:909-16.

Lynch TR, Johnson CS, Mendelson T, Robins CJ, Krishnan KRK, Blazer DG: New onset and remission of suicidal ideation among a depressed adult sample. JAD 1999:56;49-54.

Lyons-Ruth K, Lyubchik A, Wolfe R, Bronfman E. Parental depression and child attachment: hostile and helpless profiles of parent and child behavior among families at risk. In Goodman SH, Gotlieb IH (Eds.) Children of depressed parents: alternative pathways to risk for psychopathology. Washington, DC: American Psychiatric Association Press, 2002.

Lönnqvist JK. Psychiatric aspects of suicidal behaviour: depression. In The International Handbook of Suicide and Attempted Suicide. Hawton K \& van Heeringen K (Eds.) JohnWiley \& Sons, 2000.

Madianos MG, Madianou-Gefou D, Stefanis CN. Changes in suicidal behavior among nationwide general population samples across Greece. Eur Arch Psychiatry Clin Neurosci 1993;243:171-178. 
Malone KM, Corbitt EM, Li S, Mann JJ. Prolactin response to fenfluramine and suicide attempt lethality in major depression. Br J Psychiatry 1996;168(3):324-329.

Malone KM, Haas GL, Sweeney JA, Mann JJ: Major depression and the risk of attempted suicide. J Affect Disord 1995; 34: 173-185.

Malone KM, Oquendo KM, Haas GL, Ellis SP, Li S, Mann JJ: Protective factors against suicidal acts in major depression: Reasons for living. Am J Psychiatry 2000; 157: 10841088 .

de Man AF, Leduc CP, Labreche-Gauthier L. Correlates of suicidal ideation in FrenchCanadian adults and adolescents: a comparison. J Clin Psychol 1992;48(6):811-816.

Mann JJ. The neurobiology of suicide. Nat Med 1998;4:25-30.

Mann JJ. Role of the serotonergic system in the pathogenesis of major depression and suicidal behavior. Neuropsychopharmacology 1999;21:100S-105S.

Mann JJ. A current perspective of suicide and attempted suicide. Ann Intern Med 2002;136:302-311.

Mann JJ. Neurobiology of suicidal behaviour. Nat Rev Neurosci. 2003;4(10):819-28.

Mann JJ. The medical management of depression. N Engl J Med 2005;353:1819-1834.

Mann JJ, Apter A, Bertolode J, Beautrais A, Currier D, Haas A, Hegerl U, Lönnqvist J, Malone K, Marusic A, Mehlum L, Patton G, Philips M, Rutz W, Rihmer Z, Schmidtke A, Schaffer D, Silverman M, Takahashi Y, Varnik A, Ypi P, Hendin H. Suicide Prevention Strategies. A systematic review. JAMA 2005;294:2064-2074.

Mann JJ, Huang YY, Underwood MD, Kassir SA, Oppenheim S, Kelly TM, Dwork AJ, Arango V. A serotonin transporter gene promoter polymorphism (5-HTTLPR) and prefrontal cortical binding in major depression and suicide. Arch Gen Psychiatry 2000;57(8):729-38.

Mann JJ, Malone KM, Nielsen DA, Goldman D, Erdos J, Gelernter J. Possible association of a polymorphism of the tryptophan hydroxylase gene with suicidal behavior in depressed patients. Am J Psychiatry 1997;154:1451-1453.

Mann JJ, Malone KM, Psych MR, Sweeney JA, Brown RP, Linnoila M, Stanley B, Stanley M. Attempted suicide characteristics and cerebrospinal fluid amine metabolites in depressed inpatients. Neuropsychopharmacology 1996;15:576-586. 
Mann JJ, McBride PA, Brown RP, Linnoila M, Leon AC, DeMeo M, Mieczkowski T, Myers JE, Stanley M. Relationship between central and periphal serotonin indexes in depressed and suicidal psychiatric inpatients. Arch Gen Psychiatry 1992;49:442-446.

Mann JJ, Waternaux C, Haas GL, Malone KM. Toward a clinical model of suicidal behavior in psychiatric patients. Am J Psychiatry 1999;156:181-189.

Maris RW. Suicide. The Lancet 2002;360:319-326.

Marusic A, Farmer A. Genetic risk factors as possible causes of the variation in European suicide rates. Br J Psychiatry 2001;179:194-196.

McGuffin P, Katz R, Watkins S, Rutherford J. A hospital-based twin register of the heritability of DSM-IV unipolar depression. Arch gen Psychiatry 1996;53:129-136.

McGuffin P, Marusic A, Farmer A. What can psychiatric genetics offer suicidology? Crises 2001;22(2):61-65.

Melartin TK, Rytsälä HJ, Leskelä US, Lestelä-Mielonen PS, Sokero TP, Isometsä ET. Current comorbidity of psychiatric disorders among DSM-IV major depressive disorder patients in psychiatric care in the Vantaa Depression Study. J Clin Psychiatry 2002;63:126-134.

Melartin TK, Rytsälä HJ, Leskelä US, Lestelä-Mielonen PS, Sokero TP, Isometsä ET. Severity and comorbidity predict episode duration and recurrence of DSM-IV major depressive disorder. J Clin Psychiatry 2004;65: 810-819.

Melartin TK, Rytsälä HJ, Leskelä US, Lestelä-Mielonen PS, Sokero TP, Isometsä ET. Continuity is the main challenge in treating major depressive disorder in psychiatric care. J Clin Psychiatry 2005; 66: 220-227.

Melfi CA, Chawla AJ, Croghan TW, Hanna MP, Kennedy S, Sredl K. The effects of adherence to antidepressant treatment guidelines on relapse and recurrence of depression. Arch Gen Psychiatry 1998;55:1128-1132.

Merikangas KR, Zhang H, Avenevoli S, Acharyya S, Neuenschwander M, Angst J. Longitudinal trajectories of depression and anxiety in a prospective community study: the Zurich Cohort Study. Arch Gen Psychiatry 2003;60:993-1000.

Mitchell A. Depressed patients and treatment adherence. Lancet 2006;367;2041-2043.

Modestin J, Kopp W. Study on suicide in depressed inpatients. JAD 1988;15:157-162. 
Mortensen PB, Agerbo E, Erikson T, Qin P, Westergaard-Nielsen N. Psychiatric illness and risk factors for suicide in Denmark. Lancet 2000;355:9-12.

Moscicki E. Epidemiology of suicide. In Risk factors for suicide. Goldsmith S (Ed.) Washington, DC. National Academy Press, 2001

Moscicki EK, O'Carroll P, Rae DS, Locke BZ, Roy A, Regier DA. Suicide attempts in the Epidemiologic Catchment Area Study. Yale J Biol Med 1988;61:259-268.

Monroe SC, Harkness K, Simons AD, Thase ME: Life stress and the symptoms of major depression. J Nerv Ment Dis 2001;180:168-175.

Murray CJL, Lopez AD, eds. (1996). The global burden of disease: a comprehensive assessment of mortality and disability from diseases, injuries and risk factors in 1990 and projected to 2020. Cambridge, MA, Havard School of Public Health on behalf of the World Health Organization and the World Bank (Global Burden of Disease and Injury Series, Vol. I).

Murray DC. Suicidal and depressive feelings among college students. Psychol Rep 1973;33(1):175-181.

Murphy GE, Wetzel RD, Robins E, McEvoy L. Multiple risk factors predict suicide in alcoholism. Arch Gen Psychiatry 1992;49(6):459-63.

National Collaborating Centre for Mental Health Commissioned by the National Institute for Clinical Excellence (NICE). Depression: Management of depression in primary and secondary care. National Clinical Practice Guideline Number 23. 2004.

Nordström P, Åsberg M, Åberg-Wistedt A, Nordlin C. Attempted suicide predicts suicide risk in mood disorders. Acta Psychiatr Scand 1995;92:345-350.

Norlev J, Davidsen M, Sundaram V, Kjoeller M. Indicators associated with suicidal ideation and suicide attempts among 16-35-year-old Danes: A national representative population study. Suicide Life Threat Behav 2005;35:291-308.

Noyes R Jr: Suicide and panic disorder: a review. J Affect Disord 1991; 22: 1-11.

Oates MR. Adverse effects of maternal antenatal anxiety on children: causal effect or developmental continuum? Editorial. Br J Psychiatry 2002;180:478-479.

O'Connor TG, Heron J, Golding J, Beveridge M, Glover V. Maternal antenatal anxiety and children's behavioural/emotional problems at 4 years. Report from the Avon Longitudinal Study of parents and Children. Br J Psychiatry 2002;180:502-508. 
Olfson M, Marcus SC, Tedeschi M, Wan GJ. Continuity of antidepressant treatment for adults with depression in the United States. Am J Psychiatry 2006;163:101-108.

Ordway GA, Widdowson PS, Smith KS, Halaris A. Agonist binding to alpha 2-adrenoreceptors is elevated in the locus coeruleus from victims of suicide. J Neurochem 1994a;63:617-624.

Ordway GA, Smith KS, Haycock JW. Eleveted tyrosine hydroxylase in the locus coeruleus of suicide victims. J neurochem 1994b;62:680-685.

Oquendo MA, Galfalvy H, Russo S, Ellis SP, Grunebaum MF, Burke A, Mann JJ. Prospective study of clinical predictors of suicidal acts after a major depressive episode in patients with major depressive disorder or bipolar disorder. Am J Psychiatry 2004;161:1433-41.

Oquendo MA, Kamali M, Ellis SP, Grunebaum MF, Malone KM, Brodsky BS, Sackheim HA, Mann JJ. Adequacy of antidepressant treatment after discharge and the occurrence of suicidal acts in major depression: a prospective study. Am J Psychiatry 2002;159(10):1746-51.

Oquendo MA, Malone KM, Ellis SP, Sackheim HA, Mann JJ. Inadequacy of antidepressant treatment for patients with major depression who are at risk for suicidal behavior. Am J Psychiatry 1999;156:190-194.

Ostamo A, Lönnqvist J. Excess mortality of suicide attempters. Soc Psychiatry Psychiatr Epidemiol 2001;36:29-35.

Ostamo A, Lönnqvist J, Heinonen S, Leppävuori A, Liikkanen A, Marttila, Mönkkönen J. Epidemiology of parasuicides in Finland. Psychiatrica Fennica 1991;22:181-189.

Pages KP, Russo JE, Roy-Byrne PP, Ries RK, Cowley DS. Determinants of suicidal ideation: The role of substance use disorders. J Clin Psychiatry 1997;58:510-515.

Pampallona S, Bollini P, Tibaldi G, Kupelnick B, Munizza C. Patient adherence in the treatment of depression. Br J Psychiatry 2002;180:104-9.

Parker G. Parental characteristics in relation to depressive disorders. Br J Psychiatry 1979;134:138-147.

Parker G, Gibson NA, Brotchie H, Heruc G, Rees AM, Hadzi-Pavlovic D. Omega-3 fatty acids and mood disorders. Am J Psychiatry 2006;163:969-978.

Paykel ES. Methodological aspects of life event research. J Psychosom Res 1983;27:341-352.

Paykel ES, Dienelt MN: Suicide attempts following acute depression. J Nerv Ment Dis 1971; 153(4): 234-243. 
Paykel ES, Myers JK, Dienelt MN. Life events and depression: a controlled study. Arch Gen Psychiatry 1969;21:753:760.

Paykel ES, Myers JK, Lindenthal JJ, Tanner J. Suicidal feelings in the general population: a prevalence study. Br J Psychiatry 1974;124:460-469.

Paykel ES, Prusoff BA, Myers JK: Suicide attempts and recent life events. Arch Gen psychiatry $1975 ; 32: 327-333$.

Petronis KR, Samuels JF, Moscicki EK, Anthony JC. An epidemiologic investigation of potential risk factors for suicide attempts. Soc Psychiatry Psychiatr Epidemiol 1990;25:193-9.

Pfeffer CR, Normandin L, Kakuma T. Suicidal children grow up: suicidal behavior and psychiatric disorders among relatives. J Am Acad Child Adolesc Psychiatry 1994;33(8):1087-97.

Pirkis J, Burgess P, Dunt D. Suicidal ideation and suicide attempts among Australian adults. Crisis 2000;21(1):16-25.

Pirkola SP, Isometsä E, Suvisaari J, Aro H, Joukamaa M, Poikolainen K, Koskinen S, Aromaa A, Lönnqvist JK. DSM-IV mood-, anxiety-, and alcohol use disorders and their comorbidity in the Finnish general population. Results from the Health 2000 study. Soc Psychiatry Psychiatr Epidemiol 2005;40:1-10.

Placidi GP, Oquendo MA, Malone KM, Brodsky B, Ellis SP, Mann JJ. Anxiety in major depression: relationship to suicide attempts. Am J Psychiatry 2000;157:1614-1618.

van Praag HM, Plutchik R. Depression type and depression severity in relation to risk of violent suicide attempt. Psychiatry Res 1984;12:333-8.

Priester MJ, Clum GA. Perceived problem-solving abilityas a predictor of depression, hopelessness, and suicide ideation in a college population. J Counsel psychol 1993;40:79-85.

Qin P, Nordentoft M. Suicide risk in relation to psychiatric hospitalization: evidence based on longitudinal registers. Arch Gen Psychiatry 2005 Apr;62(4):427-32.

Rich CL, Ricketts JE, Fowler RC, Young D. Some differences between men and women who commit suicide. Am J Psychiatry 1988;145(6):718-22. 
Rifai AH, George CJ, Stack JA, Mann JJ, Reynolds CF III. Hopelessness in suicide attempts after acute treatment of major depression in late life. Am J Psychiatry 1994; 151: 16871690.

Ringel E. The presuicidal syndrome. Suicide Life Threat Behav 1976;6:131-149.

Robins E, Gassner S, Kayes J, Wilkinson RH, Murphy GE. The communication of suicidal intent: A study of 134 consecutive cases of successful (completed) suicide. Am J Psychiatry 1959;115(8):724-33.

Roy A. Family history of suicide. Arch Gen Psychiatry 1983;40(9):971-4.

Roy A. Genetic and biologic risk factors for suicide in depressive disorders. Psychiatr Q 1993a;64(4):345-58.

Roy A: Features associated with suicide attempts in depression: a partial replication. J Affect Disord 1993b; 27(1): 35-38

Roy A, Segal NL, Centerwall BS, Robinette CD. Suicide in twins. Arch Gen Psychiatry 1991;48(1):29-32.

Roy A, Segal NL, Sarchiapone M. Attempted suicide among living co-twins of twin suicide victims. Am J Psychiatry 1995;152(7):1075-6.

Rudd MD. An integrative model of suicidal ideation. Suicide Life Threat Behav 1990;20(1):16-30.

Rudd MD, Dahm PF, Rajab MH. Diagnostic comorbidity in persons with suicidal ideation and behavior. Am J Psychiatry 1993;150(6):928-34.

Rujescu D, Giegling I, Sato T, Hartman AM, Moller HJ. Genetic variations in tryptophan hydroxylase in suicidal behavior: analysis and meta-analysis. Biol Psychiatry 2003;54(4):465-73.

Rytsälä HJ, Melartin TK, Leskelä US, Lestelä-Mielonen PS, Sokero TP, Isometsä ET. A record-based analysis of 803 patients treated for depression in psychiatric care. J Clin Psychiatry. 2001;62:701-6.

Samuelsson M, Jokinen J, Nordström A-L, Nordström P. CSF 5-HIAA, suicide intent and hopelessness in the prediction of early suicide in male high-risk suicide attempters. Acta psychiatr Scand 2006;113:44-47. 
Sareen J, Cox BJ, Afifi TO, de Graaf R, Asmundson GJ, ten Have M, Stein MB. Anxiety disorders and risk for suicidal ideation and suicide attempts: a population-based longitudinal study of adults. Arch Gen Psychiatry 2005;62(11):1249-57.

Schaffer A, Levitt AJ, Bagby RM, Kennedy SH, Levitan RD, Joffe RT: Suicidal ideation in major depression: Sex differences and impact of comorbid anxiety. Can J Psychiatry 2000; 45: 822-826.

Schmidtke A, Bille-Brahe U, De Leo D, Kerkhof A, Bjerke T, Crepet P, Haring C, Hawton K, Lönnqvist JK, Michel K, Pommereau X, Querejeta I, Philippe I, Salander-Renberg E, Temesvary B, Wasserman D, Fricke S, Weinacker B, Sampaio-Faria JG. Attempted suicide in Europe: rates, trends and sociodemographic characteristics of suicide attempters during the period 1989-1992. Results of the WHO/EURO Multicentre Study on Parasuicide. Acta Psychiatr Scand 1996;93(5):327-38.

Schneider F, Harter M, Brand S, Sitta P, Menke R, Hammer-Filipiak U, Kudling R, Heindl A, Herold K, Frommberger U, Elmer O, Hetzel G, Witt G, Wolfersdorf M, Berger M, Gaebel W. Adherence to guidelines for treatment of depression in in-patients. $\mathrm{Br} \mathrm{J}$ Psychiatry 2005;187:462-9.

Schulberg HC, Katon W, Simon GE, Rush AJ. Treating major depression in primary care practice: an update of the Agency for Health Care Policy and Research Practice Guidelines. Arch Gen Psychiatry1998;55:1121-1127.

Schulsinger F, Kety S, Rosenthal D, Wender P. A family study of suicide. In: Shou M, Stromgren E, (Eds.) Origins, prevention and treatment of affective disorders. New York: Academic press 1979.

Schwab JJ, Warheit GJ, Holzer CE. Suicidal ideation and behavior in a general population. Dis Nerv Syst 1972;33(11):745-8.

Sher L, Mann JJ, Traskman-Benzd L, Winchel R, Huang YY, Fertuck E, Stanley BH. Lower cerebrospinal fluid homovanillic acid levels in depressed suicide attempters. J Affect Disord 2006;90(1):83-9.

Sirey JA, Bruce ML, Alexopoulos GS, Perlick DA, Raue P, Friedman SJ, Meyers BS. Perceived stigma as a predictor of treatment discontinuation in young and older outpatients with depression. Am J Psychiatry 2001;158(3):479-81.

Skegg K. Self-harm. Lancet 2005;366:1471-1483. 
Skoog I, Aevarsson O, Beskow J, Larsson L, Palsson S, Waern M, Landahl S, Ostling S. Suicidal feelings in a population sample of non-demented 85-year-olds. Am J Psychiatry 1996;153(8):1015-20.

Slater J, Depue RA: The contribution of environmental events and social support to serious suicide attempts in primary depressive disorder. J Abnorm Psychology 1981;90(4):275-285.

Smith K, Crawford S. Suicidal behavior among "normal" high school students. Suicide Life Threat Behav 1986;16(3):13-25.

Soloff PH, Lynch KG, Kelly TM, Malone KM, Mann JJ: Characteristics of suicide attempts of patients with major depressive episode and borderline personality disorder: A comparative study. Am J Psychiatry 2000; 157: 601-608.

Sorenson SB, Rutter CM. Transgenerational patterns of suicide attempt. J Consult Clin Psychol 1991;59(6):861-6; discussion 867-73.

Souery D, Van Gestel S, Massat I, Blairy S, Adolfsson R, Blackwood D, Del-Favero J, Dikeos D, Jakovljevic M, Kaneva R, Lattuada E, Lerer B, Lilli R, Milanova V, Muir W, Nothen M, Oruc L, Papadimitriou G, Propping P, Schulze T, Serretti A, Shapira B, Smeraldi E, Stefanis C, Thomson M, Van Broeckhoven C, Mendlewicz J. Tryptophan hydroxylase polymorphism and suicidality in unipolar and bipolar affective disorders: a multicenter association study. Biol Psychiatry 2001;49:405-9.

Spijker J, de Graaf R, Bijl RV, Beekman ATF, Ormel j, Nolen WA. Duration of major depressive episodes in the general population: results from the Netherlands mental Health Survey and Incidence Study (NEMESIS). Br J Psychiatry 2002;181:208-213.

Spitzer RL, Williams JBW, Gibbon M, First MB. Structured Clinical Interview for DSM-III-R Personality Disorder (SCID-II, 9/1/89) New York. Biometrics Research Department, New York State Psychiatric Institute, 1989.

SPSS for Windows, Release 9.0.1, 11.0, 12.0.1 Copyright (C) SPSS Inc. 1989-2005.

StataCorp LP. Release 9. Statistical Software for Professionals. College Station, Texas, USA.

Statham DJ, Heath AC, Madden PA, Bucholz KK, Bierut L, Dinwiddie SH, Slutske WS, Dunne MP, Martin NG. Suicidal behaviour: an epidemiological and genetic study. Psychol Med 1998;28(4):839-55.

Stephenson BJ, Rowe BH, Haynes RB, Macharia WM, Leon G. The rational clinical examination. Is this patient taking the treatment as prescribed? JAMA 1993;269(21):2779-81. 
Sullivan PF, Neale JM, Kendler KS. Genetic epidemiology of major depression: review and meta-analysis. Am J Psychiatry 2000;157:1552-1562.

Sumiyoshi T, Stockmeier CA, Overholser JC, Thompson PA, Meltzer HY. Dopamine D4 receptors and effects of guanine nucleotides on $[3 \mathrm{H}]$ raclopride binding in postmortem caudate nucleus of subjects with schizophrenia or major depression. Brain Res 1995;681:109-116.

Suokas J, Suominen K, Isometsä E, Ostamo A, Lönnqvist J. Long-term risk factors for suicide mortality after attempted suicide - findings of a 14-year follow-up study. Acta Psychiatr Scand 2001;104:117-121.

Suomen Psykiatriyhdistys (Finnish Psychiatric Association). Depression käypä hoito suositus. (The National Finnish Current Care Guidelines for the Treatment of Depression). Duodecim 2004;120:744-764.

Suominen K, Henriksson M, Suokas J, Isometsä E, Ostamo A, Lönnqvist J. Mental disorders and comorbidity in attempted suicide. Acta Psychiatr Scand 1996;94:234-40.

Suominen K, Isometsä E, Haukka J, Lönnqvist J. Substance use and male gender as risk factors for deaths and suicide. A 5-year follow-ip study after deliberate self-harm. Soc Pstchiatry Psychiatr Epidemiol 2004a;39:720-724.

Suominen K, Isometsä E, Ostamo A, Lönnqvist J. Level of suicidal intent predicts overall mortality and suicide after attempted suicide: a 12-year follow-up study. BMC Psychiatry 2004b;4:11.

Szanto K, Mulsant BH, Houck P, Dew MA, Reynolds CF 3rd. Occurrence and course of suicidality during short-term treatment of late-life depression. Arch Gen Psychiatry 2003;60:610-7.

A Task Force Report of the American Psychiatric Association. The Practice of Electroconvulsive Therapy: Recommendations for Treatment, Training, and Privileging. Washington, DC, APA, 1990.

Tautiluokitus 1996. Stakes. Helsinki: Edita, 1996.

Teasdale JD, Segal ZV, Williams JMG, Ridgeway VA, Soulsby JM, Lau MA. Cognitive vulnerability to persistent depression. Cogn Emot 1998;2:247-274.

Tedlow J, Smith M, Neault N, Polania L, Alpert J, Nierenberg A, Fava M. Melancholia and Axis II comorbidity. Compr Psychiatry 2002;43:331-335. 
Tennant C. Parental loss in childhood: its effect in adult life. Arch Gen Psychiatry 1988;45:1045-1050.

The UK ECT Review Group. Efficacy and safety of electroconvulsive therapy in depressive disorders: a systematic review and meta-analysis. Lancet 2003;361:799-808.

Tsuang MT, Faraone SV. The genetics of mood disorders. Baltimore, Johns Hopkins University Press, 1990.

Tsuno N, Besset A, Ritchie K. Sleep and depression. J Clin Psychiatry 2005;66:1254-1269.

Turecki G. Dissecting the suicide phenotype: the role of impulsive-aggressive behaviours. J Psychiatry Neurosci 2005;30(6):398-408.

Turecki G, Zhu Z, Tzenova J, Lesage A, Seguin M, Tousignant M, Chawky N, Vanier C, Lipp O, Alda M, Joober R, Benkelfat C, Rouleau GA. TPH and suicidal behavior: a study in suicide completers. Mol Psychiatry 2001;6:98-102.

Vandivort DS, Locke BZ. Suicidal ideation: its relation to depression, suicide and suicide attempt. Suicide Life Threat Behav 1979;9(4):205-218.

Van Gastel A, Schotte C, Maes M: The prediction of suicidal intent on depressed patients. Acta Psychiatr Scand 1997; 96: 254-259.

Van Praag HM, Plutchik R. Depression type and depression severity in relation to risk of violent suicide attempt. Psychiatry Res 1984;12:333-338.

Vijayakumar L, Rajkumar S. Are risk factors for suicide universal? A case-control study in India. Acta Psychiatr Scand 1999;99:407-11.

Vilhjalmsson R, Kristjansdottir G, Sveinbjarnadottir E. Factors associated with suicide ideation in adults. Soc Psychiatry Psychiatr Epidemiol 1998;33:97-103.

Vuorilehto M, Melartin T, Isometsä E. Depressive disorders in primary care: recurrent, chronic, and co-morbid. Psychol Med 2005;35:673-682.

Wallace J, Schneider T, McGuffin P. Genetics and depression. In Handbook of Depression. Gotlib IH, Hammen CL (Eds.). New York, London: The Guildford Press, 2002.

Weiner RD. Treatment optimization with ECT. Psychopharmacol Bull 1994; 30:313-320. 
Weissman MM, Bland RC, Canino GJ, Greenwald S, Hwu HG, Joyce PR, Karam EG, Lee CK, Lellouch J, Lepine JP, Newman SC, Rubio-Stipec M, Wells, JE, Wickramaratne PJ, Wittchen HU, Yeh EK. Prevalence of suicide ideation and suicide attempts in nine countries. Psychol Med 1999;29(1):9-17.

Whisman MA, Sheldon CT, Goering P. Psychiatric disorders and dissatisfaction with social relationships: does type of relationship matter? J Abnorm Psychol 2000;109:803-808.

WHO World Mental Health Survey Consortium. Prevalence, severity, and unmet need for treatment of mental disorders in the World Health Organization World Mental Health Surveys. JAMA 2004;291:2581-2590.

Wijkstra J, Lijmer J, Balk F, Geddes J, Nolen WA. Pharmacological treatment for psychotic depression. Cochrane Database Syst Rev 2005 Oct 19;(4):CD004044.

Williams JMG. Suicide and attempted suicide. 2001. Penguin. London.

Williams JMG, Barnhofer T, Crane C, Beck AT. Problem solving deteriorates following mood challenge in formerly depressed patients with a history of suicidal ideation. $\mathrm{J}$ Abnorm Psychol 2005a;114:421-431.

Williams JMG, Crane C, Barnhofer T, van der Does AJW, Segal ZV. Recurrence of suicidal ideation across depressive episodes. JAD 2006;91:189-194.

Williams JMG, Crane C, Barnhofer T, Duggan D. In: Prevention and treatment of suicidal behaviour. From science to practice. Ed. Hawton K. Oxford University Press 2005b.

Wing JK, Babor T, Brugha T, Burke J, Cooper JE, Giel R, Jablenski A, Reiger D, Sartorius N. SCAN. Schedules for Clinical Assessment in Neuropsychiatry. Arch Gen Psychiatry 1990;47:589-593.

Wittchen HU, Jacobi F. Size and burden of mental disorders in Europe - a critical review and appraisal of 27 studies. Eur Neuropsychopharmacol 2005;15:357-376.

Wolfersdorf M, Straub R. Electrodermal reactivity in the male and female depressive patients who later died by suicide. Acta Psychiatr Scand 1994;89:279-284.

World Health Organization. The ICD-10 classification of mental health and behavioral disorders: clinical descriptions and diagnostic guidelines. Geneva: WHO, 1992.

World Health Organization. The ICD-10 classification of mental health and behavioral disorders: diagnostic criteria for research. Geneva: WHO, 1993. 
World Health Organization. Country reports and charts web page. www.who.int/mental_health/prevention/suicide/country_reports/en/index.html. Accessed January 2005.

Wrigth E. Non-compliance - or how many aunts has matilda? Lancet 1993;342.909-913.

Yerevanian BI, Feusner JD, Koek RJ, Mintz J. The dexamethasone suppression test as a predictor of suicidal behavior in unipolar depression. JAD 2004;83(2-3):103-8.

Young EA, Abelson JL, Cameron OG. Effect of comorbid anxiety disorders on the hypothalamic-pituitary-adrenal axix response to a social stressor in major depression. Biol Psychiatry 2004;56:113-120.

Zhou Z, Roy A, Lipsky R, Kuchipudi K, Zhu G, Taubman J, Enoch MA, Virkkunen M, Goldman D. Haplotype-based linkage of tryptophan hydroxylase 2 to suicide attempt, major depression, and cerebrospinal fluid 5-hydroxyindoleacetic acid in 4 populations. Arch Gen Psychiatry 2005;62(10):1109-18.

Zill P, Buttner A, Eisenmenger W, Moller HJ, Bondy B, Ackenheil M. Single nucleotide polymorphism and haplotype analysis of a novel tryptophan hydroxylase isoform (TPH) gene in suicide victims. Biol psychiatry 2004;56:581-586.

Zimmerman M, Lish JD, Lush DT, Farber NJ, Plescia G, Kuzma MA. Suicidal ideation among urban medical outpatients. J Gen Intern Med 1995;10:573-576.

Zimmerman M, McDermut W, Mattia JI. Frequency of anxiety disorders in psychiatric outpatients with major depressive disorder. American Journal of Psychiatry 2000; $157: 1337-1340$.

Zisook S, Arleen G, Sledge P, Schuchter SR: Reported suicidal behavior and current suicidal ideation in a psychiatric outpatient clinic. Ann Clin Psychiatry 1994;6(1):27-31.

Ösby U, Brandt L, Correia N, Ekbom A, Sparen P: Excess mortality in bipolar and unipolar disorder in Sweden.Arch Gen Psychiatry 2001;58:844-850. 